\title{
THE HALACARID GENUS LOHMANNELLA (HALACARIDAE, ACARI): LIST OF SPECIES, NOTES ON CHARACTERS, DISTRIBUTION, ECOLOGY AND A TABULAR KEY
}

\author{
Ilse Bartsch \\ Forschungsinstitut Senckenberg, Hamburg, Germany \\ e-mail: ilse.bartsch@senckenberg.de
}

\begin{abstract}
Presently, 39 Lohmannella species are accepted as valid, but future examinations may prove some of them to be junior synonyms of others. This article lists the most important descriptive papers, as well as the former names for each of the 39 species. The characters of another five species, known by their adults, are outlined but not given a name. Based on the published data, short diagnoses as well as notes on the distribution and habitats are added. In addition, the poorly known female of Lohmannella bihamata is described and illustrated. This article provides a table of morphological characters that are meant to facilitate the identification of Lohmannella species. The genus Lohmannella is spread worldwide, inhabiting all water depths and all climatic zones; its representatives live in marine and fresh water. Although the majority of Lohmannella species have been found at sea, five species have been recovered from fresh or slightly brackish water. In the following sentences, the number of unnamed species is given in square brackets. Records of 33 [plus two] marine species are exclusively from the littoral and/or bathyal zone (0-1,000 $\mathrm{m}$ deep); records of three [plus three] species are from the deep sea (deeper than 1,000 m); and one record is from the littoral / deep sea depth range. Most species have been found in the temperate and polar areas: namely, 12 [plus two] have been recorded north of $23^{\circ} \mathrm{N}$ and 20 south of $23^{\circ} \mathrm{S}$. The data from the tropics include a single shallow water $(0-200 \mathrm{~m}$ deep) record, one unnamed species from the 400-520 m depth and one [plus two] species from the depth of more than 1,000 m. Most southern hemisphere shallow water species are morphologically distinct from the bathyal and abyssal species, as well as from the northern hemisphere species.
\end{abstract}

KEY WORDS: Halacaroidea, Lohmannella, biology, geography, diagnoses, table of characters.

DOI: 10.21684/0132-8077-2021-29-2-189-232

\section{INTRODUCTION}

Lohmannella falcata (Hodge, 1863), the type species of the genus that is nowadays called Lohmannella, is probably the first ever halacarid mite to be illustrated. It is expected to be the 'marine insect' illustrated by Baster (1758: plate 10, Fig. 7). This 'animalcula' had been extracted from coralline algae from the coast of Zeeland, the Netherlands.

What we see on the plate (Baster 1758: plate 10, Fig. 7) is the dorsal aspect of a mite with an ovate body (idiosoma), an elongate capitulum (gnathosoma) and four pairs of slender, rather long legs. The two small spots in the anterior part of the idiosoma are supposed to represent the eye pigment, while the two larger dark areas in the middle are supposed to be the gut content shining through the transparent integument. The length of the gnathosoma, until the end of the slender palps, is about 0.6 times the length of the idiosoma. The apical segment of each palp is turned outward. The legs are about similar in shape, all are slender. Species of two genera that are known to live on the coast of the Netherlands may fit the above descriptionAgaue and Lohmannella. However, the position of the eye spots and the slightly outward turned apical palpal segments suggest that it is Lohmannella.

A century after the presentation of this 'marine insect', Hodge (1863) described a marine mite which he called Leptognathus falcatus. As the generic name Leptognathus was occupied, Lohmann (1901) proposed to call the halacarid genus Trouessartella, but this name turned out to be taken as well, so the generic name Lohmannella Trouessart, 1901 (in Trouessart and Neumann 1901) was introduced. More than three decades passed until the second Lohmannella species was described, namely L. kervillei (Trouessart, 1894) (in Trouessart and Neumann 1894). Nowadays, more than two and a half centuries after the first illustration of a marine mite and one and a half centuries after the first description of a Lohmannella, the genus includes 39 species, 34 of which live in the sea, and five in fresh or slightly brackish water.

Lohmannella species are easily distinguished from other halacarid genera on the basis of their flattened, rather wide idiosoma; generally long and slender gnathosoma with parallel-sided rostrum and slender, dorsally attached palps and (except for one species) slender legs. The gnathosoma may be almost as long as, or even longer than, the idiosoma; rarely, it is distinctly shorter.

The following pages present a list of the named 39 species, including notes on the descriptions, unique morphological characters or character combinations, geographical records and biological data. 
Characters of another five species are outlined, four of which have been mentioned in previous papers but remained nameless.

The poorly known female of Lohmannella bihamata Viets, 1950 is described and the genitoanal plate of L. reticulata Viets, 1950 is illustrated. The description also illustrates and offers information on terms, which have been used when characterizing Lohmannella species. A tabular key, including 70 morphological characters, is meant to help in a preliminary identification of the species at hand. A careful check with the descriptions should follow.

\section{MATERIALS AND METHODS}

The characters presented for each one of the species have been extracted from the publications mentioned, as well as from the annotations made by the author in the past decades when studying microscopical slides of the type, non-type and/or unpublished material. Misinterpretations or different interpretations of a given character state, both by the describer and the reader, cannot be excluded.

The presentation of each species starts with a short list of publications, namely the first description and the more recent ones with either further data or a summary of morphological details. The supposed depository of the type material is added. This note does not guarantee that the types still exist. Coordinates of type localities, if not given directly in the descriptions, have been extracted from maps on the basis of the available data; accordingly, the information has to be handled with care. Short notes inform about the most important morphological characters of the species, similar looking species and distinguishing details. Geographical and ecological data are added.

The shape of the plates is characteristic and easily recognized when trying to identify a species. Fig. 1 gives a general idea of different shapes of the anterior and posterior dorsal plates, ocular and genital plates.

Table 1 presents the relevant state of the 70 characters of each of the 39 named Lohmannella species. An added column informs about the characters unique to, or that rarely occur in, Lohmannella. This table can be used for identification of adults even if not all characters are available for observation. A quick glance will inform if a striking character of an individual at hand is shared with others and in what characters the species disagree. Rare states are in parentheses and those classified as an anomaly are excluded. A question mark (?) is given in case the character state is not known or is in need of verification. The given length of the dorsal and ventral plates is that along the median axis, from the anterior to the posterior margin, the width is the greatest width. The ocular plates are often in an oblique position, rarely parallel to the median axis of the idiosoma. The length of the ocular plates is the distance between the anteriorand posterior-most corners; the width is measured at an about $90^{\circ}$ angle to the length. The outline of the dorsal plates may be influenced by handling during mounting. The striated integument of ovigerous females may be markedly expanded due to pressure or slight distortion; the plates, especially the ocular plates, are moved to the margins, hence they are no longer in a dorsal aspect. In the illustrations, marginal setae of the idiosoma are shown either in a dorsal or ventral aspect, but not in both. The length of the gnathosoma is the distance between the basal margin of the gnathosomal base and the end of the rostrum. The length of a given segment refers to its length in dorsal aspect. The length of a tarsal claw is the distance between the basal part, articulating with the central sclerite, and the apically arched margin; the width is measured in the middle of the claw. The width of the second palpal segment is measured at about $10 \mu \mathrm{m}$ distad to the often slightly widened basis.

Decimal indices are added to denote the position of a structure with reference to the median length of the idiosoma and their plates, from anterior to posterior ends, and of the gnathosoma, palps and leg segments, from basal to apical ends. When using the table of characters (Table 1), one should be aware that in a given species, the range of variants (e.g., of the number and position of setae) is mostly unknown. The classification of setaesmooth, plumulate or bipectinate - can differ due to the interpretation of what can be seen with a microscope and can be influenced by fouling or overclearing. The number of dorsal setae on the tarsi includes the solenidion. The published number of ventral setae on the tarsi may include both bipectinate and smooth, sensory ones (eupathid setae). In the present paper, the level of the solenidion on tarsi I and II, as well as the level of the dorsomedial fossary seta on tarsi III and IV, were generally chosen to separate between the basal and apical parts of a tarsus. Setae in the basal part are solid, often bipectinate, those in the apical part are smooth, often eupathid. The number of the latter setae is generally not given. 

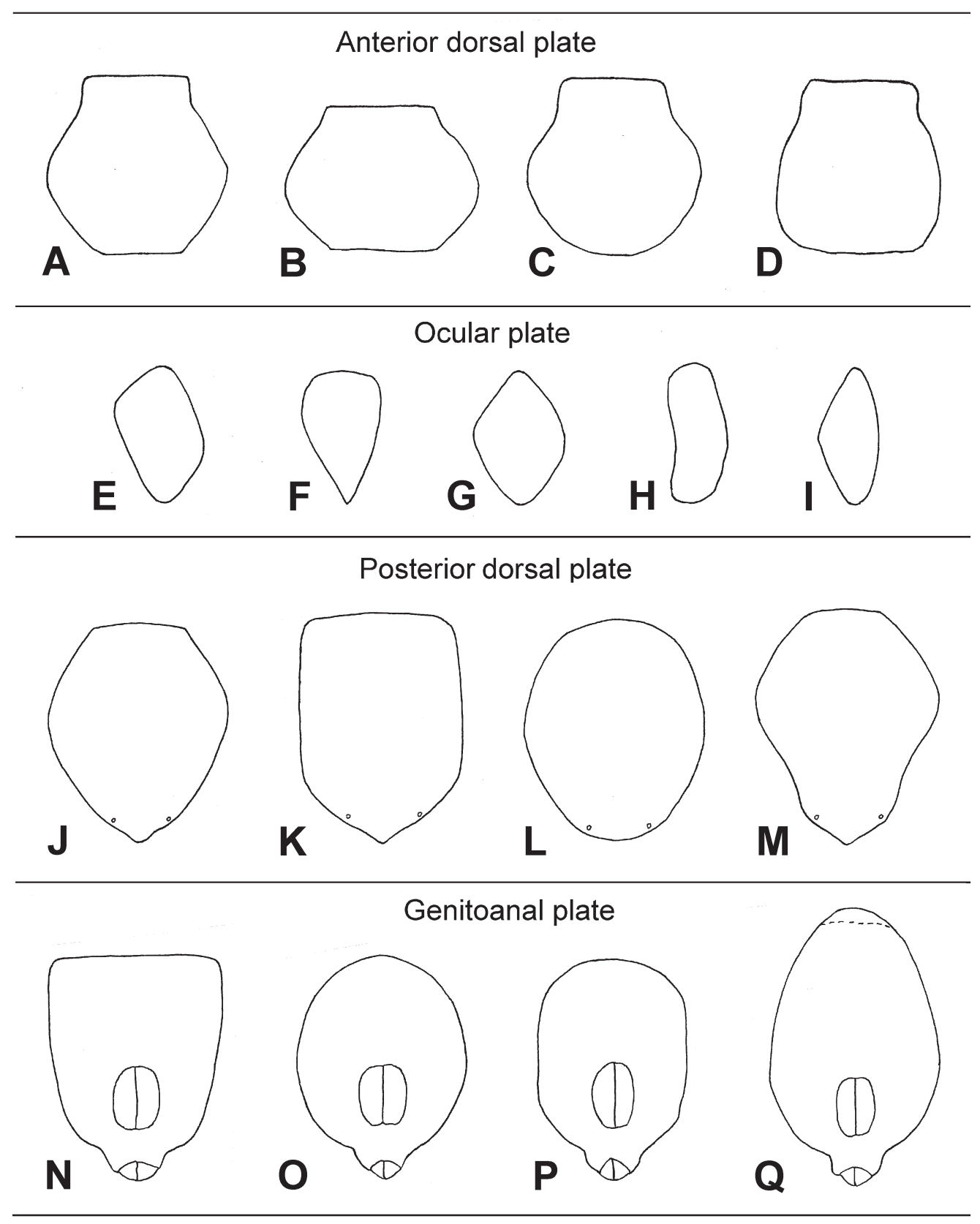

Fig. 1. Schematized shape of anterior and posterior dorsal plates, ocular and genital plates. A-D, anterior dorsal plate (AD): A - hexagonal, widest in about middle of plate, L:W ca. 0.8-1.0:1, posterior margin truncate; B-hexagonal, $\mathrm{L}: \mathrm{W}$ ca. $0.6-0.7: 1$, posterior margin truncate; $\mathrm{C}$ - bowl-shaped, lateral and posterior margins arched, posterior margin semi-circular; D — rectangular, lateral margins almost straight or slightly arched, posterior margin truncate. E-I, ocular plate (OC): E - elongate trapeziform; F-like a triangle or inverted drop, posteriorly pointed; G-diamond-shaped; $\mathrm{H}$ - elongate, length at least twice the width, almost similar in width from anterior to posterior part; I-spindle-like, margins anteriorly and posteriorly narrowed. J-M, posterior dorsal plate (PD) (the shape of the posterior margintruncate, arched or with a horn-like protruding - is often not mentioned in the descriptions of species and hence the character is excluded; the pair of glp-6 is included, though in a few species, the pores are inconspicuous or absent): $\mathrm{J}$ - somewhat hexagonal, widest at about $0.3-0.5$, anterior margin almost truncate or concave; $\mathrm{K}$ - anterior one-third of plate almost rectangular, anterior margin truncate or concave, lateral margins mostly straight, equidistant; L—ovate to almost circular, 1.1-1.3 times longer than wide, anterior and lateral margins arched; $\mathrm{M}$ - pyriform, widest at about $0.3-0.5$, posteriad margins converging. $\mathrm{N}-\mathrm{Q}$, genitoanal plate $(\mathrm{GA}): \mathrm{N}$ - anterior two-third of plate almost rectangular, anterior margin truncate (or slightly arched), lateral margins equidistant or slightly convergent; $\mathrm{O}$ - anterior half of plate semi-circular, ovoid or arched, lateral margins arched; L:W 1.2-1.5; P-anterior margin evenly arched or truncate, lateral margins almost straight, equidistant, plate 1.4-1.6 times longer than wide; Q-anterior margin oviform or truncate (illustrated in broken line), plate more than 1.4 times longer than wide, lateral margins arched. 
Abbreviations of taxonomic terms used in the text are: $\mathrm{AD}$ - anterior dorsal plate; $\mathrm{AE}$ - anterior epimeral plate; ds-1 to ds-6-first to sixth pair of dorsal idiosomatic setae, numbered from anterior to posterior; EII - area corresponding to epimeral plate II; GA — genitoanal plate; gac — genital acetabula; glp - gland pore(s), numbered glp-1 to glp-5 from anterior to posterior; GO-genital opening; L:H - ratio of length to height; L:W-ratio of length to width; mxs-1, mxs-2-basal and apical pair of maxillary setae, respectively; OCocular plate(s); P-1 to P-4 - first to fourth palpal segment; pas - parambulacral seta(e); PD — posterior dorsal plate; $\mathrm{PE}$ - posterior epimeral plate(s); pgs_-perigenital setae; sgs-subgenital setae. The legs, their segments and claws are numbered from I to IV, from anterior to posterior. The leg segments are trochanter, basifemur, telofemur, genu, tibia and tarsus.

Abbreviations of Museums:

AMNHNY, American Museum of Natural History, New York, USA.

ANIC, Australian National Insect Collection, Canberra, Australia.
MHNT, Muséum d'Histoire Naturelle de Toulouse, France.

MNHNP, Muséum National d'Histoire Naturelle, Paris, France.

MNHUB, Museum für Naturkunde der Humboldt-Univerität, Berlin (Leibniz Research Alliance of Biodiversity), Germany.

NMNHS, National Museum of Natural History, Sofia, Bulgaria.

NRS, Naturhistoriska Riksmuseet, Stockholm, Sweden.

NSMT, National Science Museum, Tokyo, Japan (Japanese Antarctic Research Expedition; NIPR, National Institute of Polar Research, Tokyo).

SMF, Senckenberg Museum, Frankfurt am M., Germany (Senckenberg Natural History Museum).

USNMNH, United States National Museum of Natural History, Washington, D.C., USA.

WAM, Western Australian Museum, Perth, Australia.

ZMH, Zoologisches Museum, Hamburg (Leibniz Institute for the Analysis of Biodiversity Change), Germany.

Table 1 (right)

Morphological characters and their states in Lohmannella species

(abbreviations: abs, absent; $\mathrm{AD}$, anterior dorsal plate; adj, adjacent; $\mathrm{AD}: \mathrm{PD}$, ratio of length of $\mathrm{AD}$ to that of PD; AE, anterior epimeral plate; alm, almost; ant, anterior; arch, arched; bwl, bowl-shaped; cav, cavate; circ , circular; clos, close to; covx, convex; curv, curved; cyl, cylindrical; deli, delicate, delicately; dia, diamond-shaped, diam, diameter; dist, distinct, distinctly; dista, distanced; ds-1 to ds-6, first to sixth pair of idiosomatic dorsal idiosomatic setae; drop, droplets; ds-1:glp-1, position of first pair of dorsal setae in relation to first pair of gland pores; $\mathrm{d} / \mathrm{v}$, dorsal/ventral setae; elong, elongate;

EII, area corresponding to epimeral plate II; fus, fused; GA, genitoanal plate; gac, genital acetabula; GA-GO:GO, ratio between length of intervall between anterior margin of GO and that of GA to length of GO; glp, gland pore(s), numbered glp-1 to glp-5; gnath, gnathosomal; GO, genital opening; gran, granulate; hex, hexagonal; incon, inconspicuous, intlock, interlocked; lat, lateral; lam, lamelliform;

lar, large, L:D, ratio length to diameter; L:W, ratio length to width; mar, margin; maz, maze-like; med, medial; mem, membraneous (striated) integument; mem(pl), membraneous integument in margin of a plate; mid, middle; min, minute; mod, moderate; mxs-1, basal pair of maxillary setae; nr, number; obl, oblong; OC, ocular plate(s); oct, octagonal; ova, ovate; ovi, oviform; pap, papillate; pas, parambulacral seta(e); PD, posterior dorsal plate; PE, posterior epimeral plate(s); pent, pentagonal; pgs, perigenital setae; pl, plate; pos, position; pos:mar, position relative to margin of plate; post, posterior; pres, present; pun, punctate; pyri, pyriform; P-2, P-4, second and fourth palpal segment; rath, rather; rect; rectangular; remov, removed; reti, reticulate; ro, rostral; s, setae; semcir, semi-circular; sep, separated; sgs, subgenital setae; sli, slightly; sma, small; smoo, smooth; stra, straight; sgs, subgenital setae; trap, trapeziform; triang, triangular; trun, truncate; v, ventral; V-shap, V-shaped; wid, wide, widely; (A) to (Q) refer to shape of plates illustrated in Fig. 1). 
The halacarid genus Lohmannella

\begin{tabular}{|c|c|c|c|c|c|c|c|}
\hline \multirow{2}{*}{\begin{tabular}{|c}
$\begin{array}{c}\text { species/ } \\
\text { character }\end{array}$ \\
Lohmannella
\end{tabular}} & \multicolumn{3}{|c|}{ idiosoma } & \multicolumn{4}{|c|}{ idiosoma, dorsal aspect } \\
\hline & $\begin{array}{l}\text { length, female } \\
\quad \text { (in } \mu \mathrm{m} \text { ) }\end{array}$ & $\begin{array}{l}\text { length, male } \\
\quad(\text { in } \mu \mathrm{m})\end{array}$ & $\mathrm{L}: \mathrm{W}$ & $\begin{array}{c}\text { dorsal plates, } \\
\text { ornamen- } \\
\text { tation } \\
\text { of surface }\end{array}$ & $\begin{array}{c}\text { porose areolae } \\
\text { absent or } \\
\text { present on }\end{array}$ & & $\begin{array}{c}\text { no. of } \\
\text { corneae }\end{array}$ \\
\hline abyssalis & 385 & $?$ & $1.3: 1$ & smoo & abs & abs & 0 \\
\hline africana & 378 & $?$ & $1.5: 1$ & reti & none & abs & 0 \\
\hline andrei & $?$ & 360 & $1.4: 1$ & smoo & abs & abs & 0 \\
\hline antarctica & $430-470$ & $420-430$ & $1.4-1.5: 1$ & reti & $\mathrm{AD}, \mathrm{OC}, \mathrm{PD}$ & V-shap & 1 \\
\hline arenaria & $241-256$ & $215-263$ & $1.2: 1$ & reti-gran & none & abs & (1) \\
\hline beringi & $?$ & $?$ & $?$ & $?$ & $?$ & $?$ & $?$ \\
\hline bihamata & 410 & 500 & $1.3-1.4: 1$ & gran-reti & none & abs & 1 \\
\hline bispina & $395-425$ & $?$ & $1.4: 1$ & punc & none & abs & 0 \\
\hline consimilis & 385 & $?$ & $1.2: 1$ & smoo & PE & abs & 1 \\
\hline $\begin{array}{l}\text { curvimandi- } \\
\text { bulata }\end{array}$ & 420 & 390 & $1.5-1.6: 1$ & reti & none & abs & 0 \\
\hline cvetkovi & 318 & $324-408$ & $1.4: 1$ & reti & none & abs & 0 \\
\hline cygna & 515 & $?$ & $1.2: 1$ & smoo & none & abs & 0 \\
\hline dictyota & 375 & $?$ & $1.2: 1$ & reti & PD & elong & 2 \\
\hline falcata & $270(?)-515$ & $335-490$ & $1.3: 1$ & smoo & none & abs & 2 \\
\hline fukushimai & $495-560$ & $491-582$ & $1.3: 1$ & pap & none & abs & $1(-2)$ \\
\hline gaussi & $431-568$ & $407-500$ & $1.4: 1$ & gran & $\mathrm{AD}, \mathrm{OC}, \mathrm{PD}$ & V-shap & 2 \\
\hline grandipora & $390-456$ & $395-425$ & $1.5: 1$ & punc-pan & none & abs & 0 \\
\hline heptapegoni & $?$ & 318 & $1.4: 1$ & $?$ & none & abs & 0 \\
\hline hureaui & 547 & $?$ & $1.4: 1$ & reti & none & abs & 1 (faint) \\
\hline kerguelensis & $?$ & $420-450$ & $1.5: 1$ & maz-gran & none & abs & 1 \\
\hline kervillei & $353-447$ & $340-353$ & $1.3: 1$ & $?$ & none & abs & 2 \\
\hline lamellipes & 466 & $?$ & $1.2: 1$ & reti & none & abs & 0 \\
\hline masatierrae & $?$ & 344 & $1.3: 1$ & $?$ & $?$ & $?$ & 2 \\
\hline multisetosa & $340-447$ & $?$ & $1.3: 1$ & smoo & none & abs & $1(-2)$ \\
\hline multispina & 255 & $?$ & $1.4: 1$ & $?$ & $?$ & $?$ & $?$ \\
\hline njoerdri & 314 & 310 & $1.3: 1$ & pap & none & abs & 2 \\
\hline norvegica & $425-434$ & $?$ & $1.4: 1$ & $?$ & $?$ & $?$ & 2 \\
\hline nudipes & 390 & $?$ & $1.4: 1$ & smoo & none & abs & 2 \\
\hline pinggi & $278-437$ & $382-424$ & $1.4: 1$ & deli reti & none & abs & 1 \\
\hline rectangulops & 395 & $?$ & $1.4: 1$ & $?$ & none & abs & $1+(1)$ \\
\hline reducta & $318-335$ & 278 & $1.4: 1$ & deli pap & none & abs & 2 \\
\hline reticulata & $390-428$ & $344-390$ & $1.3: 1$ & reti & $\mathrm{AD}, \mathrm{OC}, \mathrm{PD}$ & V-shap & 1 \\
\hline rustica & $297-335$ & 273 & $1.3: 1$ & $?$ & none & abs & 2 \\
\hline septemsetosa & 447 & 410 & $1.3: 1$ & reti-maz & none & abs & (1) \\
\hline setosa & 264 & $?$ & $1.3: 1$ & tuber & none & abs & (1) \\
\hline stammeri & $297-324$ & $297-320$ & $1.5: 1$ & smo & none & abs & 0 \\
\hline steueri & $328-345$ & $335-345$ & $1.5: 1$ & pap & none & abs & 2 \\
\hline subfalcata & $295-314$ & $?$ & $1.2: 1$ & smoo & none & abs & 2 \\
\hline sulensis & 386 & $?$ & $1.1: 1$ & gran & none & abs & $1(-2)$ \\
\hline
\end{tabular}


I. Bartsch

\begin{tabular}{|c|c|c|c|c|c|c|c|}
\hline \multirow{2}{*}{$\begin{array}{c}\begin{array}{c}\text { species/ } \\
\text { character }\end{array} \\
\text { Lohmannella }\end{array}$} & \multicolumn{7}{|c|}{ idiosoma, dorsal aspect } \\
\hline & $\begin{array}{c}\mathrm{AD}, \text { shape } \\
\text { (confer Fig. 1) }\end{array}$ & $\mathrm{AD}, \mathrm{L}: \mathrm{W}$ & $\begin{array}{c}\mathrm{AD}, \\
\text { posterior } \\
\text { margin, } \\
\text { shape }\end{array}$ & $\begin{array}{l}\text { OC, shape } \\
\text { (confer } \\
\text { Fig. 1) }\end{array}$ & OC, L:W & $\begin{array}{l}\text { PD, shape } \\
\text { (confer } \\
\text { Fig. 1) }\end{array}$ & PD, L:W \\
\hline abyssalis & hex(B) & $0.6: 1$ & trun & $\operatorname{trap}(\mathrm{E})$ & $1.7: 1$ & $\mathrm{obl}(\mathrm{J})$ & $1.1: 1$ \\
\hline africana & hex(B) & $0.7: 1$ & trun & $\operatorname{trap}(\mathrm{E})$ & $1.9: 1$ & obl-rect(K) & $1.4: 1$ \\
\hline andrei & $\operatorname{rect}(\mathrm{D})$ & $1.0: 1$ & trun & $\operatorname{diam}(\mathrm{G})$ & $1.5: 1$ & ova(L) & $1.1: 1$ \\
\hline antarctica & hex(A) & $0.9: 1$ & trun & $\operatorname{diam}(\mathrm{G})$ & $1.4: 1$ & $\operatorname{rect}(\mathrm{K})$ & $1.3: 1$ \\
\hline arenaria & wid(B) & $0.6: 1$ & trun & ova & $1.3: 1$ & ova $(\mathrm{L})$ & $1.1: 1$ \\
\hline beringi & $?$ & $?$ & $?$ & $?$ & $?$ & $?$ & $?$ \\
\hline bihamata & bwl(C) & $0.9: 1$ & arch & $\operatorname{trap}(\mathrm{E})$ & $1.9: 1$ & $\operatorname{rect}(\mathrm{K})$ & $1.3-1.4: 1$ \\
\hline bispina & $\operatorname{rect}(\mathrm{D})$ & $0.8: 1$ & sli arch & $\operatorname{trap}(\mathrm{E})$ & $1.7: 1$ & $\operatorname{rect}(\mathrm{K})$ & $1.3: 1$ \\
\hline consimilis & hex(A) & $0.8: 1$ & trun & $\operatorname{trap}(\mathrm{E})$ & $1.7: 1$ & pyri(M) & $1.2: 1$ \\
\hline $\begin{array}{l}\text { curvimandi- } \\
\text { bulata }\end{array}$ & $\operatorname{rect}(\mathrm{D})$ & $0.8-1.0: 1$ & trun & $\operatorname{triang}(\mathrm{F})$ & $1.5-1.8$ & circ-rect $(\mathrm{K}, \mathrm{L})$ & $1.2-1.3: 1$ \\
\hline cvetkovi & hex(B) & $0.7: 1$ & trun & $\operatorname{triang}(\mathrm{F})$ & $1.6: 1$ & $\operatorname{circ}-\operatorname{rect}(\mathrm{K}, \mathrm{L})$ & $1.0-1.3: 1$ \\
\hline cygna & wid(B) & $0.6: 1$ & trun & $\operatorname{trap}(\mathrm{E})$ & $1.4: 1$ & pyri(M) & $1.0: 1$ \\
\hline dictyota & $\operatorname{rect}(\mathrm{D})$ & $1.0: 1$ & trun & $\operatorname{trap}(E)$ & $1.7: 1$ & $\operatorname{rect}(\mathrm{K})$ & $1.7: 1$ \\
\hline falcata & hex(A) & $0.8: 1$ & trun & $\operatorname{trap}(\mathrm{E})$ & $1.5: 1$ & ova(L) & $1.1-1.3: 1$ \\
\hline fukushimai & hex(B) & $0.8: 1$ & trun & $\operatorname{trap}(\mathrm{E})$ & $1.4: 1$ & pyri(M) & 1.1:1 \\
\hline gaussi & hex $(\mathrm{A} / \mathrm{B})$ & $0.8: 1$ & trun & $\operatorname{trap}(\mathrm{E})$ & $1.8: 1$ & $\operatorname{hex}(J)$ & $1.3-1.4: 1$ \\
\hline grandipora & hex(B) & $0.8: 1$ & trun & $\operatorname{trap}(E)$ & 2.0 & $\operatorname{rect}(\mathrm{K})$ & $1.4: 1$ \\
\hline heptapegoni & $\operatorname{rect}(\mathrm{D})$ & $0.9: 1$ & trun & elong(I) & $1.9: 1$ & $\operatorname{rect}(\mathrm{K})$ & $1.3: 1$ \\
\hline hureaui & bwl(C) & $0.7: 1$ & arch & $\operatorname{trap}(\mathrm{E})$ & $1.7: 1$ & $\operatorname{rect}(\mathrm{K})$ & $1.6: 1$ \\
\hline kerguelensis & hex(B) & $0.7: 1$ & trun & $\operatorname{trap}(\mathrm{E})$ & $2.0: 1$ & pyri(L/M) & $1.4: 1$ \\
\hline kervillei & hex(A) & $0.8: 1$ & trun & $\operatorname{trap}(\mathrm{E})$ & $1.5-1.7: 1$ & $\operatorname{rect}(\mathrm{K})$ & $1.2: 1$ \\
\hline lamellipes & hex(B) & $0.6: 1$ & trun & $\operatorname{trap}(\mathrm{E})$ & $1.5: 1$ & $\operatorname{rect}(\mathrm{K})$ & $1.1: 1$ \\
\hline masatierrae & hex(A) & $1.0: 1$ & trun & $\operatorname{trap}(\mathrm{E})$ & $1.5: 1$ & $\operatorname{rect}(\mathrm{K})$ & $1.3: 1$ \\
\hline multisetosa & hex(A) & $0.8: 1$ & trun & $\operatorname{trap}(\mathrm{E})$ & $1.5: 1$ & $\operatorname{rect}(\mathrm{K})$ & $1.2: 1$ \\
\hline multispina & hex(B) & $0.8: 1$ & trun & $\operatorname{triang}(\mathrm{I})$ & $1.8: 1$ & 1/3-rect(L) & $1.2: 1$ \\
\hline njoerdri & hex(A) & $0.8: 1$ & trun & $\operatorname{trap}(\mathrm{E})$ & $1.6: 1$ & $\operatorname{rect}(\mathrm{L})$ & $1.2: 1$ \\
\hline norvegica & hex(A) & $1.0: 1$ & trun & $\operatorname{trap}(\mathrm{E})$ & $1.8: 1$ & $\operatorname{rect}(\mathrm{K})$ & $1.3: 1$ \\
\hline nudipes & hex(A) & $1.0: 1$ & trun & $\operatorname{trap}(\mathrm{E})$ & $1.5: 1$ & ova(L) & $1.3: 1$ \\
\hline pinggi & hex(A) & $1,0: 1$ & trun & elong(H) & $2.4-3.0: 1$ & $\operatorname{oct}(\mathrm{L})$ & $1.2-1.3: 1$ \\
\hline rectangulops & bwl(C) & $1.1: 1$ & semcirc & $\operatorname{trap}(\mathrm{E})$ & 2.3:1 & $\operatorname{rect}(\mathrm{K})$ & 1.1:1 \\
\hline reducta & hex(A) & $0.9: 1$ & trun & $\operatorname{trap}(\mathrm{E})$ & $1.6: 1$ & $\operatorname{rect}(\mathrm{K})$ & $1.3: 1$ \\
\hline reticulata & $\operatorname{hex}(\mathrm{A})$ & $0.9: 1$ & trun & $\operatorname{trap}(\mathrm{E})$ & $2.1: 1$ & $\operatorname{hex}(J)$ & $1.3: 1$ \\
\hline rustica & hex(A) & $0.9: 1$ & trun & $\operatorname{trap}(\mathrm{E})$ & $1.4: 1$ & rect & $1.2: 1$ \\
\hline septemsetosa & $\operatorname{rect}(\mathrm{D})$ & $0.9: 1$ & trun & ova-trap & $1.9: 1$ & $\operatorname{rect}(\mathrm{K})$ & $1.3: 1$ \\
\hline setosa & bwl(D) & $1.0: 1$ & semcirc & elong $(\mathrm{H})$ & $2.1-2.4: 1$ & $\operatorname{rect}(\mathrm{K})$ & $1.1: 1$ \\
\hline stammeri & hex(A) & $0.9: 1$ & trun & $\operatorname{triang}(\mathrm{F})$ & $2.3: 1$ & $\operatorname{rect}(\mathrm{K})$ & $1.2: 1$ \\
\hline steueri & hex(A) & $1.0: 1$ & trun & $\operatorname{trap}(\mathrm{E})$ & $1.5: 1$ & ova(L) & $1.3: 1$ \\
\hline subfalcata & hex(A) & $0.9: 1$ & trun & $\operatorname{trap}(\mathrm{E})$ & $1.6: 1$ & $\operatorname{circ}(\mathrm{L})$ & $1.0: 1$ \\
\hline sulensis & $\operatorname{wid}(\mathrm{B})$ & $0.7: 1$ & trun & $\operatorname{trap}(\mathrm{E})$ & $1.6: 1$ & pyri(J) & $1.0: 1$ \\
\hline
\end{tabular}


The halacarid genus Lohmannella

\begin{tabular}{|c|c|c|c|c|c|c|c|c|c|}
\hline $\begin{array}{l}\text { species/ } \\
\text { character }\end{array}$ & & & & idiosoma, & orsal asp & & & & \\
\hline Lohmannella & $\begin{array}{c}\mathrm{PD}, \\
\text { anterior } \\
\text { margin }\end{array}$ & $\begin{array}{l}\text { AD:PD, } \\
\text { length }\end{array}$ & $\begin{array}{c}\text { enlarged } \\
\text { dorsal setae }\end{array}$ & $\begin{array}{c}\text { ds-1, } \\
\text { position : } \\
\text { length } \\
\text { of AD }\end{array}$ & $\begin{array}{l}\text { ds-1: } \\
\text { glp-1 }\end{array}$ & $\begin{array}{l}\text { position } \\
\text { ds- } 2 \text {, } \\
\text { mem or } \\
\text { plate }\end{array}$ & $\begin{array}{l}\text { position } \\
\text { ds-3 }\end{array}$ & $\begin{array}{l}\text { position } \\
\text { of ds-4, } \\
\text { mem or } \\
\text { plate }\end{array}$ & $\begin{array}{c}\text { position } \\
\text { ds-5 : } \\
\text { length } \\
\text { of PD }\end{array}$ \\
\hline abyssalis & trun & $0.7: 1$ & ds-1 & 0.2 & level & $\mathrm{AD}$ & mem & mem & 0.4 \\
\hline africana & trun & $0.6: 1$ & ds-1 & 0.2 & level & mem & mem & mem & 0.4 \\
\hline andrei & $\operatorname{arch}$ & $0.8: 1$ & ds-1 & 0.3 & $?$ & $?$ & mem & PD & 0.4 \\
\hline antarctica & trun & $0.7: 1$ & ds-1 & 0.3 & sli ant & mem & mem & mem & $0.4-0.5$ \\
\hline arenaria & $\operatorname{arch}$ & $0.6: 1$ & ds-1 & 0.2 & sli ant & $\mathrm{AD}$ & mem & mem & 0.4 \\
\hline beringi & $?$ & $?$ & $?$ & $?$ & $?$ & $?$ & $?$ & $?$ & $?$ \\
\hline bihamata & trun & $0.7-1.0: 1$ & ds-1, (ds-3) & 0.3 & level & mem & mem & mem & $0.3-0.4$ \\
\hline bispina & trun & $0.6: 1$ & ds-1 & 0.3 & post & mem & PD & mem & 0.4 \\
\hline consimilis & $\operatorname{arch}$ & $0.7: 1$ & ds-1 & 0.2 & ant & mem & PD & mem & 0.5 \\
\hline $\begin{array}{l}\text { curvimandi- } \\
\text { bulata }\end{array}$ & $\operatorname{arch}$ & $0.5-0.7: 1$ & none & 0.3 & $?$ & $\mathrm{OC}$ & mem & PD & 0.6 \\
\hline cvetkovi & trun & $0.7-0.8: 1$ & none & 0.2 & ant & $\mathrm{OC}$ & mem & PD & $0.4-0.6$ \\
\hline cygna & arch & $0.6: 1$ & ds-1 & 0.3 & sli ant & $\mathrm{AD}$ & PD mar & mem & 0.3 \\
\hline dictyota & trun & $0.6: 1$ & (ds-1) & 0.2 & ant & mem & PD & mem & 0.4 \\
\hline falcata & $\operatorname{arch}$ & $0.6-0.7: 1$ & ds-1 & $0.2-0.3$ & $?$ & mem & mem & mem & 0.4 \\
\hline fukushimai & arch & $0.6: 1$ & ds-1 & 0.3 & level & mem & mem & mem & 0.4 \\
\hline gaussi & trun & $0.5: 1$ & ds-1 & 0.3 & level & mem & PD & mem & 0.4 \\
\hline grandipora & trun & $0.6: 1$ & ds-1 & 0.2 & sli post & mem & PD mar & mem & 0.5 \\
\hline heptapegoni & trun & $0.8: 1$ & ds-1 & 0.2 & ca level & $\mathrm{OC}$ & mem & PD & 0.3 \\
\hline hureaui & trun & $0.7: 1$ & ds-1 & 0.4 & level & mem & mem & mem & 0.4 \\
\hline kerguelensis & $\operatorname{arch}$ & $0.5: 1$ & ds- 1 & 0.3 & sli post & mem & PD mar & mem & 0.4 \\
\hline kervillei & trun & $0.7: 1$ & ds-1, ds-3 & 0.2 & ant & mem & mem & mem & 0.4 \\
\hline lamellipes & trun & $0.6: 1$ & ds-1 & 0.3 & ant & mem & PD mar & mem & 0.3 \\
\hline masatierrae & trun & $0.8: 1$ & $?, \mathrm{ds}-3$ & 0.2 & ant & mem & mem & mem & 0.3 \\
\hline multisetosa & $\operatorname{arch}$ & $0.7: 1$ & ds-1 & 0.3 & $?$ & mem & mem & mem & 0.5 \\
\hline multispina & trun & $0.6: 1$ & ds-1 & 0.3 & sli post & $\mathrm{AD}$ & PD mar & $\mathrm{OC}$ & 0.4 \\
\hline njoerdri & trun & $0.6: 3$ & ds-1 & 0.3 & $?$ & mem & mem & mem & 0.5 \\
\hline norvegica & trun & $0.8-0.9: 1$ & ds-1 & 0.2 & $?$ & mem & mem & mem & $?$ \\
\hline nudipes & $\operatorname{arch}$ & $0.7: 1$ & ds-1 & 0.2 & ant & $\mathrm{AD}$ & mem & mem & 0.4 \\
\hline pinggi & trun-arch & $0.7: 1$ & ds-1 & 0.2 & ant & mem & mem & mem & 0.3 \\
\hline rectangulops & trun & $1.1: 1$ & $(\mathrm{ds}-1 ?) \mathrm{ds}-3$ & 0.2 & ant & mem & mem & mem & 0.3 \\
\hline reducta & $\operatorname{arch}$ & $0.6: 1$ & ds-1 & 0.2 & $?$ & mem & mem & mem & 0.5 \\
\hline reticulata & trun & $0.7: 1$ & ds-1 & 0,2 & ant & mem & PD mar & mem & 0.6 \\
\hline rustica & arch & $0.8: 1$ & ds-1 & 0.3 & $?$ & mem & mem & mem & 0.4 \\
\hline septemsetosa & trun & 0.7 & ds-1 & 0.3 & ant & mem & mem & mem & 0.4 \\
\hline setosa & trun & $1.1: 1$ & ds- 1 , ds-3 & 0.2 & ant & mem & mem & mem & 0.1 \\
\hline stammeri & trun & $1.0: 1$ & ds-1 & 0.3 & level & $\mathrm{OC}$ & mem & PD & 0.4 \\
\hline steueri & arc-trun & $0.7: 1$ & ds-1 & 0.2 & $?$ & mem & mem & mem & mem \\
\hline subfalcata & $\operatorname{arch}$ & $0.7: 1$ & ds-1 & 0.3 & $?$ & mem & mem & mem & 0.4 \\
\hline sulensis & $\operatorname{arch}$ & $0.8: 1$ & ds-1 & 0.3 & $?$ & mem & mem & mem & 0.5 \\
\hline
\end{tabular}


I. Bartsch

\begin{tabular}{|c|c|c|c|c|c|c|c|c|c|}
\hline species/ & & & & idiosom & $\mathrm{a}$, dorsal a & spect & & & \\
\hline Lohmannella & $\begin{array}{l}\text { glp, replaced } \\
\text { by setae }\end{array}$ & glp-1, size & $\begin{array}{l}\text { glp-2, } \\
\text { size }\end{array}$ & $\begin{array}{l}\text { glp-3, } \\
\text { size }\end{array}$ & $\begin{array}{l}\text { glp-4, } \\
\text { size }\end{array}$ & $\begin{array}{l}\text { glp-5, } \\
\text { size }\end{array}$ & $\begin{array}{c}\text { glp-1, } \\
\text { position: } \\
\text { AD } \\
\text { length }\end{array}$ & $\begin{array}{l}\text { glp-2, } \\
\text { position }\end{array}$ & $\begin{array}{c}\text { glp-3, } \\
\text { position: } \\
\text { OC length }\end{array}$ \\
\hline abyssalis & none & $\bmod$ & sma & sma & sma & sma & 0.3 & mem & 0.6 \\
\hline africana & none & mod-lar & $\bmod$ & mod-lar & mod-lar & mod-lar & 0.2 & mem & 0.6 \\
\hline andrei & none & $?$ & $?$ & $?$ & $?$ & $?$ & $?$ & $?$ & $?$ \\
\hline antarctica & none & $\bmod$ & $\bmod$ & $\bmod$ & $\bmod$ & $\bmod$ & 0.4 & mem & 0.6 \\
\hline arenaria & none & mod & $\bmod$ & $\bmod$ & $\bmod$ & $\bmod$ & 0.2 & mem & 0.6 \\
\hline beringi & $?$ & $?$ & $?$ & $?$ & $?$ & ? & ? & $?$ & ? \\
\hline bihamata & none & $\bmod$ & $\bmod$ & $\bmod$ & $\bmod$ & $\bmod$ & 0.2 & $\operatorname{mem}(\mathrm{pl})$ & 0.6 \\
\hline bispina & none & mod & $\bmod$ & $\bmod$ & $\bmod$ & $\bmod$ & 0.2 & $\operatorname{mem}(\mathrm{pl})$ & 0.6 \\
\hline consimilis & none & lar & $\bmod$ & $\bmod$ & $\bmod$ & $\bmod$ & 0.3 & mem & 0.5 \\
\hline $\begin{array}{l}\text { curvimandi- } \\
\text { bulata }\end{array}$ & none & abs & abs & abs & abs & abs & abs & abs & abs \\
\hline cvetkovi & none & sma & abs & abs & abs & sma & 0.3 & abs & abs \\
\hline cygna & none & mod & sma & sma & sma & sma & 0.4 & mem & 0.5 \\
\hline dictyota & none & larg & $\bmod$ & $\bmod$ & $\bmod$ & $\bmod$ & 0.3 & mem & $0.6-0.7$ \\
\hline falcata & none & sma (abs) & incon & incon & incon & incon & $?$ & $?$ & $?$ \\
\hline fukushimai & glp-3, glp-4 & mod & sma & set & set & mod & 0.3 & mem & seta 0.6 \\
\hline gaussi & none & mod & $\bmod$ & $\bmod$ & $\bmod$ & $\bmod$ & 0.2 & $\mathrm{AE}$ & 0.5 \\
\hline grandipora & none & mod & sma & lar & lar & $\bmod$ & 0.2 & mem & 0.7 \\
\hline heptapegoni & none & $\bmod$ & abs & abs & abs & abs & 0.2 & abs & $?$ \\
\hline hureaui & none & $\bmod$ & $\bmod$ & $\bmod$ & $\bmod$ & lar & 0.4 & mem & 0.5 \\
\hline kerguelensis & none & mod & $\bmod$ & $\bmod$ & $\bmod$ & $\bmod$ & 0.2 & mem & 0.5 \\
\hline kervillei & none & $\min$ & incon & incon & $\min$ & $\min$ & 0.4 & $?$ & $?$ \\
\hline lamellipes & none & $\bmod$ & $\bmod$ & $\bmod$ & $\bmod$ & $\bmod$ & 0.4 & mem & 0.6 \\
\hline masatierrae & none & $\bmod$ & $\bmod$ & lar & lar & lar & 0.4 & mem & 0.6 \\
\hline multisetosa & none & incon & incon & incon & incon & incon & $?$ & $?$ & $?$ \\
\hline multispina & none & $\bmod$ & $\bmod$ & $\bmod$ & $\bmod$ & $\bmod$ & 0.2 & mem & 0.5 \\
\hline njoerdri & none & incon & incon & incon & incon & incon & $?$ & $?$ & $?$ \\
\hline norvegica & none & $?$ & $?$ & $?$ & $?$ & $?$ & $?$ & $?$ & $?$ \\
\hline nudipes & none & $\min$ & incon & incon & incon & sma & 0.4 & $?$ & $?$ \\
\hline pinggi & $\bmod$ & mod & $\bmod$ & $\bmod$ & $\bmod$ & $\bmod$ & 0.4 & mem & 0.3 \\
\hline rectangulops & none & mod-lar & $\bmod$ & $\bmod$ & $\bmod$ & $\bmod$ & 0.4 & mem & 0.6 \\
\hline reducta & none & incon & incon & incon & incon & incon & $?$ & $?$ & $?$ \\
\hline reticulata & none & $\bmod$ & $?$ & $\bmod$ & $\bmod$ & $\bmod$ & 0.4 & $?$ & 0.6 \\
\hline rustica & none & incon & incon & incon & $\min$ & $\min$ & $?$ & $?$ & $?$ \\
\hline septemsetosa & none & $\bmod$ & mod & mod & $\bmod$ & $\bmod$ & 0.3 & mem & 0.4 \\
\hline setosa & none & $\bmod$ & mod & lar & sma & sma & 0.4 & mem & 0.8 \\
\hline stammeri & none & $\bmod$ & incon & incon & $\min$ & $\min$ & 0.3 & incon & $?$ \\
\hline steueri & none & incon & incon & incon & incon & incon & $?$ & $?$ & $?$ \\
\hline subfalcata & none & incon & incon & incon & incon & incon & $?$ & $?$ & $?$ \\
\hline sulensis & none & incon & incon & incon & incon & incon & $?$ & $?$ & $?$ \\
\hline
\end{tabular}


The halacarid genus Lohmannella

\begin{tabular}{|c|c|c|c|c|c|c|c|}
\hline \multirow{2}{*}{\begin{tabular}{|c}
$\begin{array}{c}\text { species/ } \\
\text { character }\end{array}$ \\
Lohmannella
\end{tabular}} & \multicolumn{5}{|c|}{ idiosoma, dorsal aspect } & \multicolumn{2}{|c|}{ ventral aspect } \\
\hline & $\begin{array}{c}\text { glp-3, } \\
\text { position, } \\
\text { OC:margin } \\
\text { (lat/med) }\end{array}$ & $\begin{array}{c}\text { glp-4, } \\
\text { position : } \\
\text { PD length }\end{array}$ & $\begin{array}{l}\text { glp-4, } \\
\text { position : } \\
\text { PD lateral } \\
\text { margin }\end{array}$ & $\begin{array}{c}\text { glp-5, } \\
\text { position : } \\
\text { PD margin } \\
\text { (posterior) }\end{array}$ & $\begin{array}{c}\text { distance } \\
\text { between pair } \\
\text { of glp-5:PD } \\
\text { width }\end{array}$ & AE L:W & $\begin{array}{c}\mathrm{AE}, \\
\text { posterior } \\
\text { margin }\end{array}$ \\
\hline abyssalis & near med & 0.4 & near & sli dista & $0.3: 1$ & $0.4: 1$ & trun \\
\hline africana & near med & 0.4 & near & near & $0.9: 1$ & $0.5: 1$ & trun \\
\hline andrei & $?$ & $?$ & $?$ & $?$ & $?$ & $0.6: 1$ & trun \\
\hline antarctica & lat & 0.4 & dista & dista & $0.2: 1$ & $0.6: 1$ & trun \\
\hline arenaria & near med & 0.3 & near & dista & $0.5: 1$ & $0.4: 1$ & $\operatorname{arch}$ \\
\hline beringi & $?$ & $?$ & $?$ & $?$ & $?$ & $?$ & $?$ \\
\hline bihamata & near lat & 0.2 & near & near & $0.6-0.7: 1$ & $0.4: 1$ & trun \\
\hline bispina & near med & 0.4 & near & near & $0.6: 1$ & $0.5: 1$ & $\operatorname{arch}$ \\
\hline consimilis & near lat & 0.4 & dista & dista & $0.2: 1$ & $0.5: 1$ & trun-cav \\
\hline $\begin{array}{l}\text { curvimandi- } \\
\text { bulata }\end{array}$ & abs & abs & abs & abs & abs & $0.5: 1$ & $\operatorname{arch}$ \\
\hline cvetkovi & abs & abs & abs & dista & $0.2: 1$ & $0.4: 1$ & $\operatorname{arch}$ \\
\hline cygna & med & 0.4 & dista & near & $0.2: 1$ & $0.4: 1$ & trun \\
\hline dictyota & in med & 0.5 & dista & near & $0.2: 1$ & $0.6: 1$ & trun \\
\hline falcata & $?$ & $?$ & $?$ & $?$ & $?$ & $0.5: 1$ & trun \\
\hline fukushimai & seta med & seta 0.4 & dista & near & $0.2: 1$ & $0.4: 1$ & trun-cav \\
\hline gaussi & near lat & 0.4 & dista & near & $0.2: 1$ & $0.5: 1$ & trun \\
\hline grandipora & med corner & 0.4 & near & near & $0.5: 1$ & $0.5: 1$ & trun \\
\hline heptapegoni & abs & abs & abs & abs & $?$ & $0.7: 1$ & $\operatorname{arch}$ \\
\hline hureaui & near lat & 0.3 & sli dista & near & $0.4: 1$ & 0.5 & $\operatorname{arch}$ \\
\hline kerguelensis & ca. mid & 0.5 & dista & rath dista & $0.3: 1$ & 0.5 & trun \\
\hline kervillei & $?$ & 0.7 & dista & dista & $0.3: 1$ & 0.5 & trun \\
\hline lamellipes & near med & $0.3-0.4$ & dista & near & $?$ & $0.5: 1$ & trun \\
\hline masatierrae & near med & 0.3 & near & near & $0.4: 1$ & $0.6: 1$ & trun \\
\hline multisetosa & $?$ & $?$ & $?$ & $?$ & $?$ & $0.5: 1$ & trun \\
\hline multispina & in med & 0.4 & in mar & dista & $0.5: 1$ & $0.5: 1$ & trun \\
\hline njoerdri & $?$ & $?$ & $?$ & $?$ & $?$ & $0.5: 1$ & trun \\
\hline norvegica & $?$ & $?$ & $?$ & $?$ & $?$ & $0.5: 1$ & trun \\
\hline nudipes & $?$ & $?$ & $?$ & dista & $0.2: 1$ & $0.6: 1$ & curv \\
\hline pinggi & near med & 0.3 & remov & dista & $0.3-0.4: 1$ & $0.5: 1$ & trun-cav \\
\hline rectangulops & $\mathrm{med} / \mathrm{mid}$ & 0.2 & in mar & dista & $0.4: 1$ & $0.5: 1$ & trun \\
\hline reducta & $?$ & $?$ & $?$ & $?$ & $?$ & $?$ & $?$ \\
\hline reticulata & near med & 0.4 & remov & dista & $0.4: 1$ & $?$ & trun-cav \\
\hline rustica & $?$ & 0.6 & remov & dista & 0.1:1 & $0.5: 1$ & trun \\
\hline septemsetosa & mid & 0.4 & near & near & $0.5: 1$ & $0.5: 1$ & trun \\
\hline setosa & near med & 0.2 & near & dista & $0.3: 1$ & $0.4: 1$ & trun-cav \\
\hline stammeri & $?$ & 0.7 & dista & dista & $0.3: 1$ & $0.7: 1$ & $\operatorname{arch}$ \\
\hline steueri & $?$ & $?$ & $?$ & $?$ & $?$ & $0.5: 1$ & trun \\
\hline subfalcata & $?$ & $?$ & $?$ & $?$ & $?$ & $0.5: 1$ & trun \\
\hline sulensis & $?$ & $?$ & $?$ & $?$ & $?$ & $0.4: 1$ & trun \\
\hline
\end{tabular}


I. Bartsch

\begin{tabular}{|c|c|c|c|c|c|c|c|c|}
\hline \multirow{2}{*}{$\begin{array}{c}\begin{array}{c}\text { species/ } \\
\text { character }\end{array} \\
\text { Lohmannella }\end{array}$} & \multicolumn{8}{|c|}{ idiosoma, ventral aspect } \\
\hline & $\begin{array}{c}\text { AE, } \\
\text { number } \\
\text { of setae }\end{array}$ & $\begin{array}{l}\text { PE, } \\
\text { number } \\
\text { of } d / v \\
\text { setae }\end{array}$ & $\begin{array}{c}\text { female } \\
\text { GA, L:W }\end{array}$ & $\begin{array}{c}\text { female, } \\
\text { anterior GA } \\
\text { (confer } \\
\text { Fig. 1) }\end{array}$ & $\begin{array}{c}\text { female } \\
\text { GA, shape } \\
\text { of anterior } \\
\text { margin }\end{array}$ & $\begin{array}{c}\text { female, } \\
\text { length } \\
\text { GA- } \\
\text { GO:GO }\end{array}$ & $\begin{array}{c}\text { female, } \\
\text { number } \\
\text { of pgs }\end{array}$ & $\begin{array}{c}\text { male } \\
\text { GA, L:W }\end{array}$ \\
\hline abyssalis & 8 & $2 / ?$ & $1.3: 1$ & $\operatorname{rect}(\mathrm{N})$ & trun & $0.7: 1$ & 17 & $?$ \\
\hline africana & 8 & $2 / 3$ & $1.5: 1$ & ova $(Q)$ & trun-ova & $1.2: 1$ & 16 & $?$ \\
\hline andrei & 6 & $?$ & $?$ & $?$ & $?$ & $?$ & $?$ & $1.3: 1$ \\
\hline antarctica & 8 & $2 / 3$ & $1.3: 1$ & $\operatorname{rect}(\mathrm{N})$ & trun & $1.3: 1$ & 17 & $1.5: 1$ \\
\hline arenaria & 8 & $2 / 3$ & $1.4: 1$ & ovi(O) & ova & $0.8: 1$ & 16 & $1.4: 1$ \\
\hline beringi & $?$ & $?$ & $?$ & $?$ & $?$ & $?$ & $?$ & $?$ \\
\hline bihamata & 8 & $2 / 3$ & $1.6: 1$ & $\operatorname{oct}(\mathrm{P})$ & arch-trun & $0.9: 1$ & $\sim 21$ & $1.5: 1$ \\
\hline bispina & 8 & $2 / 3$ & $1.4: 1$ & ova $(Q)$ & ovi & $1.3: 1$ & $16-17$ & $?$ \\
\hline consimilis & 8 & $2 / 3$ & $1.2: 1$ & $\operatorname{rect}(\mathrm{N})$ & trun & $1.0: 1$ & 15 & $?$ \\
\hline $\begin{array}{l}\text { curvimandi- } \\
\text { bulata }\end{array}$ & 8 & $1 / 3$ & $?$ & $?$ & $?$ & $?$ & 4 & $1.2: 1$ \\
\hline cvetkovi & 6 & $1 / 3$ & $1.2: 1$ & ova $(\mathrm{O})$ & arch-trun & $0.7: 1$ & 4 & $1.3: 1$ \\
\hline cygna & 8 & $3 / 3$ & $1.3: 1$ & $\operatorname{rect}(\mathrm{N})$ & trun & $0.7: 1$ & 18 & $?$ \\
\hline dictyota & 8 & $2 / 3$ & $1.3: 1$ & $\operatorname{rect}(\mathrm{N})$ & trun & $1.6: 1$ & 43 & $?$ \\
\hline falcata & 8 & $2 / 3$ & $1.5: 1$ & ovi(Q) & ova & $1.3: 1$ & 32 & $1.5-1.6: 1$ \\
\hline fukushimai & 8 & $2 / 3$ & $1.3: 1$ & $\operatorname{rect}(\mathrm{N})$ & trun & $0.7: 1$ & $\sim 22$ & $1.4: 1$ \\
\hline gaussi & 8 & $2 / 3$ & $1.3: 1$ & $\operatorname{rect}(\mathrm{N})$ & trun & $1.4: 1$ & 20 & $1.2-1.3: 1$ \\
\hline grandipora & $8-10$ & $2 / 3$ & $1.5: 1$ & ovi(P) & $\operatorname{arch}$ & $1.3: 1$ & 16 & $1.5: 1$ \\
\hline heptapegoni & 6 & $? / 3$ & $?$ & $?$ & $?$ & $?$ & $?$ & $1.2: 1$ \\
\hline hureaui & 8 & $2 / 3$ & $1.3: 1$ & $\operatorname{circ}(\mathrm{O})$ & arch & $0.7: 1$ & $26-28$ & $1.3: 1$ \\
\hline kerguelensis & 8 & $2 / 3$ & $?$ & $?$ & $?$ & $?$ & $?$ & $1.4: 1$ \\
\hline kervillei & 8 & $2 / 3$ & $1.5: 1$ & $\operatorname{rect}(\mathrm{P})$ & trun & $1.0: 1$ & $26-34$ & $1.3: 1$ \\
\hline lamellipes & 6 & $2 / 3$ & $1.2: 1$ & ova $(Q)$ & trun & $1.4: 1$ & 14 & $?$ \\
\hline masatierrae & 8 & $2(?) / 3$ & $?$ & $?$ & $?$ & $?$ & $?$ & $1.3: 1$ \\
\hline multisetosa & 8 & $2 / 3$ & $1.5: 1$ & ova $(Q)$ & ova & $0.7: 1$ & $50-74$ & $?$ \\
\hline multispina & 8 & $2 / 3$ & $1.3: 1$ & $\operatorname{rect}(\mathrm{N})$ & arch & $1.7: 1$ & 10 & $1.4: 1$ \\
\hline njoerdri & 8 & $2 / 3$ & $?$ & $\operatorname{rect}(\mathrm{N}) ?$ & trun & $1.5: 1$ & $\sim 16$ & $1.3: 1$ \\
\hline norvegica & 6 & $2(?) / 3$ & $1.5: 1$ & $\operatorname{circ}(\mathrm{O} / \mathrm{P})$ & $\operatorname{arch}$ & $1.6: 1$ & 28 & $?$ \\
\hline nudipes & 8 & $2 / 3$ & $1.3: 1$ & $\operatorname{rect}(\mathrm{N} / \mathrm{P})$ & trun & $0.9: 1$ & 31 & $?$ \\
\hline pinggi & 8 & $2 / 3$ & $1.6: 1$ & $\operatorname{rect}(\mathrm{N})$ & trun & $1.1: 1$ & $16-18$ & $1.3: 1$ \\
\hline rectangulops & $6(?)$ & $2(?) / 3$ & $1.2: 1$ & $\operatorname{rect}(\mathrm{N} / \mathrm{P})$ & arch & $0.9: 1$ & 21 & $1.2: 1$ \\
\hline reducta & 8 & $2 / 3$ & $1.6: 1$ & $\operatorname{rect}(\mathrm{N})$ & trun & $1.4: 1$ & 31 & $1.5: 1$ \\
\hline reticulata & 8 & $2 / 3$ & $1.2: 1$ & $\operatorname{rect}(\mathrm{N})$ & trun & $1.1: 1$ & 19 & $1.2: 1$ \\
\hline rustica & 8 & $2 / 3$ & $1.5: 1$ & ova $(\mathrm{P})$ & arch & $1.1: 1$ & $32-39$ & $1.4: 1$ \\
\hline septemsetosa & 8 & $2 / 3$ & $1.3: 1$ & ovi(Q) & trun & $1.1: 1$ & 17 & $1.4: 1$ \\
\hline setosa & 8 & $2 / 3$ & $1.6: 1$ & $\operatorname{rect}(\mathrm{P})$ & arch & $0.7: 1$ & 18 & $?$ \\
\hline stammeri & 6 & $1 / 3$ & $1.2-1.3: 1$ & ova $(O)$ & arch & $1.0: 1$ & 11 & $1.6: 1$ \\
\hline steueri & 6 & $1(?) / 3$ & $1.5: 1$ & $\operatorname{rect}(\mathrm{P})$ & arch-trun & $1.2: 1$ & 27 & $1.4-1.5: 1$ \\
\hline subfalcata & 8 & $2 / 3$ & $1.5: 1$ & $\operatorname{ova}(\mathrm{O})$ & arch & $1.1: 1$ & $43-45$ & $?$ \\
\hline sulensis & $(7-) 8$ & $2 / 3$ & $1.4: 1$ & ova $(\mathrm{P})$ & $\operatorname{arch}$ & $1.4: 1$ & 48 & $?$ \\
\hline
\end{tabular}


The halacarid genus Lohmannella

\begin{tabular}{|c|c|c|c|c|c|c|c|}
\hline \multirow{2}{*}{$\begin{array}{c}\begin{array}{c}\text { species/ } \\
\text { character }\end{array} \\
\text { Lohmannella }\end{array}$} & \multicolumn{4}{|c|}{ idiosoma, ventral aspect } & \multicolumn{3}{|c|}{ gnathosoma } \\
\hline & $\begin{array}{l}\text { male GA, } \\
\text { shape } \\
\text { (confer } \\
\text { Fig. 1) }\end{array}$ & $\begin{array}{c}\text { male GA, } \\
\text { shape of } \\
\text { anterior } \\
\text { margin }\end{array}$ & $\begin{array}{c}\text { male, } \\
\text { length } \\
\text { GA-GO:GO }\end{array}$ & $\begin{array}{l}\text { male, } \\
\text { number } \\
\text { of pgs }\end{array}$ & $\begin{array}{l}\text { gnathosoma, } \\
\text { length }\end{array}$ & $\begin{array}{c}\text { length, } \\
\text { gnathosoma: } \\
\text { idiosoma } \\
(\text { in } \mu \mathrm{m})\end{array}$ & $\begin{array}{l}\text { length, } \\
\text { rostrum:base }\end{array}$ \\
\hline abyssalis & $?$ & $?$ & $?$ & $?$ & 233 & $0.6: 1$ & $1.8: 1$ \\
\hline africana & $?$ & $?$ & $?$ & $?$ & 266 & $0.7: 1$ & $1.6: 1$ \\
\hline andrei & $\operatorname{circ}(\mathrm{O})$ & $\operatorname{arch}$ & $1.9: 1$ & ca. 30 & ca. 210 & $0.6: 1$ & $1.1: 1$ \\
\hline antarctica & $\operatorname{rect}(\mathrm{N})$ & trun & $2.0: 1$ & $\sim 64$ & 267 & $0.6: 1$ & $1.3: 1$ \\
\hline arenaria & ovi(Q) & ovi-triang & $2.0: 1$ & $\sim 32$ & 193 & $0.8: 1$ & $1.8: 1$ \\
\hline beringi & $?$ & $?$ & $?$ & $?$ & $?$ & $?$ & $?$ \\
\hline bihamata & $\operatorname{ova}(\mathrm{P})$ & $\operatorname{arch}$ & $1.2-1.3: 1$ & $\sim 85$ & 286 & $0.6: 1$ & ca. $1.0: 1$ \\
\hline bispina & $?$ & $?$ & $?$ & 55 & 190 & $0.5: 1$ & $?$ \\
\hline consimilis & $?$ & $?$ & $?$ & $?$ & 230 & $0.6: 1$ & $1.3: 1$ \\
\hline $\begin{array}{l}\text { curvimandi- } \\
\text { bulata }\end{array}$ & ovi(Q) & ovi & $0.9: 1$ & 46 & $?$ & $?$ & $?$ \\
\hline cvetkovi & ova/circ $(\mathrm{O})$ & arch-trun & 0.8 & 44 & $?$ & $?$ & $?$ \\
\hline cygna & $?$ & $?$ & $?$ & $?$ & 485 & $0.9: 1$ & $2.0: 1$ \\
\hline dictyota & $?$ & $?$ & $?$ & $?$ & 255 & $0.7: 1$ & $?$ \\
\hline falcata & $\operatorname{rect}(\mathrm{Q})$ & trun & $2.0: 1$ & $70-80$ & $180-288$ & $0.5-0.6: 1$ & $1.3-1.4: 1$ \\
\hline fukushimai & $\operatorname{rect}(\mathrm{N})$ & trun & $1.1: 1$ & $\sim 70$ & $504-560$ & $0.9-1.0: 1$ & $1.2: 1$ \\
\hline gaussi & $\operatorname{rect}(\mathrm{N})$ & trun & $1.9: 1$ & $\sim 54-62$ & $\sim 385$ & $0.7-0.8: 1$ & $1.9-2.0: 1$ \\
\hline grandipora & $\operatorname{ova}(\mathrm{P} / \mathrm{Q})$ & ovi-trun & $1.8: 1$ & $\sim 50-75$ & 305 & $\sim 0.6: 1$ & $?$ \\
\hline heptapegoni & ovi(Q) & ovi & $1.4: 1$ & 33 & 144 & $0.5: 1$ & $?$ \\
\hline hureaui & $\operatorname{circ}(\mathrm{O})$ & arch & $1.1: 1$ & 68 & $?$ & $?$ & $?$ \\
\hline kerguelensis & $\operatorname{rect}(\mathrm{N})$ & trun & $1.6: 1$ & $\sim 56$ & $310-320$ & $0.7: 1$ & $1.6: 1$ \\
\hline kervillei & $\operatorname{rect}(\mathrm{P})$ & $\operatorname{arch}$ & $1.6: 1$ & $\sim 66$ & $167-179$ & $0.5: 1$ & $0.4: 1$ \\
\hline lamellipes & $?$ & $?$ & $?$ & $?$ & $?$ & $?$ & $?$ \\
\hline masatierrae & $\operatorname{rect}(\mathrm{P})$ & $\operatorname{arch}$ & $1.4: 1$ & $\sim 70$ & $?$ & $?$ & $?$ \\
\hline multisetosa & $?$ & $?$ & $?$ & $?$ & $217-260$ & $0.6-0.7: 1$ & $0.7: 1$ \\
\hline multispina & ovi(Q) & arch-trunc & $1.8: 1$ & 35 & $\sim 186$ & $0.7: 1$ & $?$ \\
\hline njoerdri & $\operatorname{rect}(\mathrm{Q})$ & trun & $2,0: 1$ & 45 & 182 & $0.6: 1$ & $1.3: 1$ \\
\hline norvegica & $?$ & $?$ & $?$ & $?$ & 205 & $0.5: 1$ & $1.5: 1$ \\
\hline nudipes & $?$ & $?$ & $?$ & $?$ & 182 & $0.5: 1$ & $?$ \\
\hline pinggi & $\operatorname{rect}(\mathrm{N})$ & trun & $1.8: 1$ & $\sim 58$ & $192-227$ & $\sim 0.6: 1$ & $1.2: 1$ \\
\hline rectangulops & $\operatorname{rect}(\mathrm{P})$ & wid arch & $1.2: 1$ & 60 & $?$ & $?$ & $?$ \\
\hline reducta & $\operatorname{rect}(\mathrm{N})$ & trun & $1.9: 1$ & 64 & $167-173$ & $0.5: 1$ & $1.1: 1$ \\
\hline reticulata & $\operatorname{rect}(\mathrm{N})$ & trun & $1.9: 1$ & 65 & 215 & $0.6: 1$ & $0.9-1.1: 1$ \\
\hline rustica & $\operatorname{ova}(\mathrm{P})$ & arch & $1.4: 1$ & 55 & 172-199 & $0.6-0.7: 1$ & $1.0: 1$ \\
\hline septemsetosa & $\operatorname{rect}(\mathrm{Q})$ & trun & $1.5: 1$ & 61 & 284 & $0.7: 1$ & $1.7: 1$ \\
\hline setosa & $?$ & $?$ & $?$ & $?$ & $\sim 160$ & $0.6: 1$ & $?$ \\
\hline stammeri & ovi(Q) & ovi & $1.4: 1$ & 35 & 207 & $0.7: 1$ & $1.1: 1$ \\
\hline steueri & $\operatorname{rect}(\mathrm{P})$ & trunc-arch & $1.5-1.6: 1$ & 38 & 166 & $0.5: 1$ & $1.1: 1$ \\
\hline subfalcata & $?$ & $?$ & $?$ & $?$ & 260 & $0.8: 1$ & $1.7: 1$ \\
\hline sulensis & $?$ & $?$ & $?$ & $?$ & 354 & $0.9: 1$ & $1.4: 1$ \\
\hline
\end{tabular}


I. Bartsch

\begin{tabular}{|c|c|c|c|c|c|c|c|}
\hline species/ & & & & nathosoma & & & \\
\hline Lohmannella & $\begin{array}{l}\text { position } \\
\text { of basal seta: } \\
\text { rostrum } \\
\text { (length) }\end{array}$ & $\begin{array}{c}\mathrm{P}-1, \\
\text { arangement }\end{array}$ & $\begin{array}{c}\text { P-2, shape } \\
\text { (ventral } \\
\text { margin) }\end{array}$ & $\begin{array}{l}\text { P-2, length: } \\
\text { diameter }\end{array}$ & $\begin{array}{l}\text { length, } \\
\text { P-2 : P-4 }\end{array}$ & $\begin{array}{c}\mathrm{P}-2, \\
\mathrm{nr} \text { of ventral } \\
\text { spines }\end{array}$ & $\begin{array}{c}\text { P-2, basal } \\
\text { seta, } \\
\text { position }\end{array}$ \\
\hline abyssalis & $?$ & sep P-1diam & curv & $5.3: 1$ & $\sim 3.9: 1$ & 1 & 0.6 \\
\hline africana & $?$ & adj & sli curv & $8.9: 1$ & $3.4: 1$ & 1 & 0.7 \\
\hline andrei & gnath base & adj & $\operatorname{covx}$ & $6.9: 1$ & $5.1: 1$ & 0 & 0.3 \\
\hline antarctica & 0.6 & adj & strai & 7.5:1 & $2.8: 1$ & 0 & 0.3 \\
\hline arenaria & 0.7 & adj & strai & $5.0-6.1: 1$ & $2.4: 1$ & 2 & 0.3 \\
\hline beringi & $?$ & $?$ & $?$ & $?$ & $3.4: 1$ & $?$ & $?$ \\
\hline bihamata & 0.6 & adj & strai & $5.5: 1$ & $2.9: 1$ & 0 & 0.3 \\
\hline bispina & $?$ & adj & strai & $6.1-7.0: 1$ & $6.4-7.0: 1$ & 2 & 0.7 \\
\hline consimilis & 0.6 & adj & $\operatorname{covx}$ & $5.4: 1$ & 2.1:1 & 0 & 0.3 \\
\hline $\begin{array}{l}\text { curvimandi- } \\
\text { bulata }\end{array}$ & $?$ & $?$ & covx & $5.8: 1$ & $3.0: 1$ & 0 & 0.7 \\
\hline cvetkovi & $?$ & $?$ & alm strai & $5.2: 1$ & $3.9: 1$ & 0 & 0.7 \\
\hline cygna & 0.8 & adj & sli covx & 10.0:1 & $3.6: 1$ & 0 & 0.3 \\
\hline dictyota & $?$ & fus & strai & $8.2: 1$ & $\sim 2.6: 1$ & 1 & 0.2 \\
\hline falcata & 0.2 & adj & strai & $6.2: 1$ & $2.6-2.8: 1$ & 0 & 0.2 \\
\hline fukushimai & 0.8 & adj & curv & 11.8:1 & $2.3-2.4: 1$ & 0 & 0.2 \\
\hline gaussi & 0.8 & adj & curv & ca. $10.0: 1$ & $2.6: 1$ & 0 & 0.3 \\
\hline grandipora & $?$ & adj & strai & $8.0-9.7: 1$ & 4.6:1 & $1(-2)$ & 0.6 \\
\hline heptapegoni & $?$ & $?$ & alm strai & $5.5: 1$ & $1.5: 1$ & 0 & 0.6 \\
\hline hureaui & $?$ & $?$ & strai & $?$ & $?$ & 0 & $?$ \\
\hline kerguelensis & 0.8 & adj & strai & 7.1:1 & $2.9: 1$ & 0 & 0.2 \\
\hline kervillei & $0.4-0.5$ & adj & curv & $2.7: 1$ & $3.4: 1$ & 0 & 0.2 \\
\hline lamellipes & $?$ & adj & strai & $8.1: 1$ & $2.3: 1$ & $4-5$ & 0.5 \\
\hline masatierrae & $?$ & adj & strai & $?$ & $?$ & 0 & 0.3 \\
\hline multisetosa & 0.7 & adj & $\operatorname{covx}$ & $6.5: 1$ & 3.2 & 0 & 0.3 \\
\hline multispina & $?$ & adj & $?$ & $6.8: 1$ & $?$ & $3-4$ & $?$ \\
\hline njoerdri & 0.6 & adj & $?$ & $5.8: 1$ & 4.3:1 & 0 & 0.2 \\
\hline norvegica & 0.2 & adj & curv & 4.1:1 & $4.8: 1$ & 0 & 0.3 \\
\hline nudipes & $?$ & alm adj & $?$ & $?$ & $?$ & 0 & 0.4 \\
\hline pinggi & $0.2-0.3$ & adj & strai & $5.4-5.6$ & $3.6: 1$ & 0 & 0.2 \\
\hline rectangulops & $?$ & $?$ & $?$ & $?$ & $?$ & 0 & 0.3 \\
\hline reducta & 0.6 & adj & strai & $5.8: 1$ & $4.6: 1$ & 0 & 0.2 \\
\hline reticulata & 0.5 & adj & strai & $5.8: 1$ & $3.5: 1$ & 0 & 0.3 \\
\hline rustica & 0.6 & adj & curv & $5.3: 1$ & $3.2: 1$ & 0 & $0.2-0.3$ \\
\hline septemsetosa & 0.8 & adj & strai & $7.7: 1$ & $2.7: 1$ & 0 & 0.2 \\
\hline setosa & $?$ & adj & strai & $6.0: 1$ & $?$ & 0 & 0.3 \\
\hline stammeri & 0.6 & sli sep & $\operatorname{cov} x$ & $6.2: 1$ & $5.8: 1$ & 0 & 0.6 \\
\hline steueri & 0.6 & adj & strai & $4.6: 1$ & $4.3: 1$ & 0 & 0.2 \\
\hline subfalcata & 0.8 & sep $1 / 2$ diam & curv & 7.8:1 & $3.3: 1$ & 0 & 0.2 \\
\hline sulensis & 0.7 & intlock & curv & $7.2: 1$ & $2.5: 1$ & 0 & 0.1 \\
\hline
\end{tabular}


The halacarid genus Lohmannella

\begin{tabular}{|c|c|c|c|c|c|c|}
\hline species/ & & & & legs & & \\
\hline Lohmannella & $\begin{array}{l}\text { legs, } \\
\text { shape }\end{array}$ & $\begin{array}{l}\text { leg I, } \\
\text { length : } \\
\text { idiosoma }\end{array}$ & $\begin{array}{l}\text { leg I, length } \\
\text { I-3:I-5 }\end{array}$ & $\begin{array}{l}\text { ventral setae } \\
\text { (bipectinate } \\
\text { included) } \\
\text { on I-4 to IV-4 }\end{array}$ & $\begin{array}{l}\text { bipectinate setae } \\
\text { of I-4 to IV-4 }\end{array}$ & $\begin{array}{c}\text { ventral setae } \\
\text { (bipectinate included) } \\
\text { of I-5 to IV-5 }\end{array}$ \\
\hline abyssalis & cyl & $0.7: 1$ & $1.3: 1$ & $4,2,1,1$ & $4,1,0,1$ & $5,4,2,2$ \\
\hline africana & cyl & $0.7: 1$ & $1.4: 1$ & $4,2,1,1$ & $4,1,0,1$ & $6,5,4,4$ \\
\hline andrei & cyl & $0.8: 1$ & $1.1: 1$ & $2,2, ?, ?$ & $2,2, ?, ?$ & $4,4 ?, ?, ?$ \\
\hline antarctica & cyl & $0.7: 1$ & $1.1: 1$ & $4,3,1,1$ & $4,0,0,0$ & $6(-7), 5,3-4,3-4$ \\
\hline arenaria & cyl & $0.9: 1$ & $1.3: 1$ & $4,2,1,1$ & $4,1,0,0$ & $6,4-5,3,3$ \\
\hline beringi & $?$ & $?$ & $?$ & $?, ?, ?, ?$ & $?, ?, ?, ?$ & $?, ?, ?, ?$ \\
\hline bihamata & cyl & $0.6-0.7: 1$ & $1.2: 1$ & $3,3,1,1$ & $3,1,0,0$ & $6,4-5,3,4$ \\
\hline bispina & $?$ & $?$ & $?$ & $?, ?, ?, ?$ & $?, ?, ?, ?$ & $6, ?, ?, ?$ \\
\hline consimilis & cyl & $0.8: 1$ & $1.1: 1$ & $4,3,1,1$ & $4,1,0,1$ & $6,5,2-3,3$ \\
\hline $\begin{array}{l}\text { curvimandi- } \\
\text { bulata }\end{array}$ & cyl & $?$ & $1.0: 1$ & $4, ?, ?, ?$ & $4, ?, ?, ?$ & $6, ?, ?, ?$ \\
\hline cvetkovi & cyl & $?$ & $1.3: 1$ & $4, ?, ?, ?$ & $4, ?, ?, ?$ & $6, ?, ?, ?$ \\
\hline cygna & cyl & $0.8: 1$ & $1.4: 1$ & $5,5,3,4$ & $5,1,0,0$ & $8,6,6,6$ \\
\hline dictyota & cyl & $0.8: 1$ & $1.2: 1$ & $3,2,1,2$ & $2,0,0,0$ & $7-8,5,4,4$ \\
\hline falcata & cyl & $0.7: 1$ & $1.1-1.2: 1$ & $4,4,2,2$ & $4, ?, 0, ?$ & $(5-) 6,5,4,3$ \\
\hline fukushimai & cyl & $1.0-1.2: 1$ & $1.2: 1$ & $4(-6), 4,2,2$ & $2(-3), 2(-3), 0,1$ & $7(-8), 6,6,5$ \\
\hline gaussi & cyl & $0.9: 1$ & $1.0-1.2: 1$ & $4,3-4,1,1-2$ & $4,2,0,1$ & $7,6,6,5$ \\
\hline grandipora & cyl & $0.6: 1$ & $?$ & $4,3-2,1,1-2$ & $4,1-2,0,1-2$ & $6,5,4,3-4$ \\
\hline heptapegoni & cyl & $?$ & $1.2: 1$ & 2, 2, ?,? & ?, ?, ?, ? & $4,4, ?, ?$ \\
\hline hureaui & cyl & $?$ & $?$ & $?, ?, ?, ?$ & $?, ?, ?, ?$ & $6, ?, ?, ?$ \\
\hline kerguelensis & cyl & $0.7: 1$ & $1.3: 1$ & $4,4,1,1$ & $4,2,0,1$ & $7,6,6,5$ \\
\hline kervillei & cyl & $0.6-0.7: 1$ & $1.3: 1$ & $2,2,1,1$ & $2,1,0,1$ & $6,5,2-3,2-3$ \\
\hline lamellipes & lam & $?$ & $?$ & $?, ?, 3, ?$ & $?, ?, 0, ?$ & $?, ?, ?, ?$ \\
\hline masatierrae & cyl & $?$ & $?$ & $?, ?, ?, ?$ & $?, ?, ?, ?$ & $?, ?, ?, ?$ \\
\hline multisetosa & cyl & $0.7: 1$ & $1.2: 1$ & $3,3, ?, 2$ & $3,0, ?, 0$ & $6,4,3-4,3$ \\
\hline multispina & cyl & $?$ & $?$ & $?, ?, ?, ?$ & $?, ?, ?, ?$ & $(5-) 6, ?, ?, ?$ \\
\hline njoerdri & cyl & $0.7: 1$ & $1.3: 1$ & $4,3,1,1$ & $3-4,1,0,1$ & $6,5,3,4$ \\
\hline norvegica & cyl & $0.6: 1$ & $1.2: 1$ & $2, ?, ?, ?$ & $1, ?, ?, ?$ & $6, ?, ?, ?$ \\
\hline nudipes & cyl & $0.6: 1$ & $1.0: 1$ & $2,1,1,1$ & $1,0,0,1$ & $5,4-5,3,3$ \\
\hline pinggi & cyl & $0.7: 1$ & $1.1-1.2: 1$ & $4,4,2,(1-) 2$ & $4,2,0.1-2$ & $7,6,3-4,3-4$ \\
\hline rectangulops & cyl & $?$ & $?$ & $?, ?, ?, ?$ & $?, ?, ?, ?$ & $5,5, ?, ?$ \\
\hline reducta & cyl & $0.6: 1$ & $1.3: 1$ & $3,2, ?, 1$ & $3,1, ?, 0$ & $4,3,2,2$ \\
\hline reticulata & cyl & $0.6: 1$ & $1.3: 1$ & $3-4,2(-3), 1,1$ & $3-4,2,0.0$ & $6,5,3,3$ \\
\hline rustica & cyl & $0.6: 1$ & $1.2: 1$ & $2,2-3,1-2,1$ & $2,1,0,0$ & $6,5,3,3$ \\
\hline septemsetosa & cyl & $0.8: 1$ & $1.3: 1$ & $4,4,2,2$ & $4,4,0,2$ & $6-7,6,5,5$ \\
\hline setosa & cyl & $?$ & $?$ & $?, ?, ?, ?$ & $?, ?, ?, ?$ & $?, ?, ?, ?$ \\
\hline stammeri & cyl & $0.7: 1$ & $1.3: 1$ & $3,2,1,1$ & $0 ?, 0,0,0$ & $4,4,3,3$ \\
\hline steueri & cyl & $0.6-0.7: 1$ & $1.2: 1$ & $3,3,2,2$ & $2-3,1,0,0$ & $5,4,2,2$ \\
\hline subfalcata & cyl & $1.0-1.1: 1$ & $1.0: 1$ & $3,3,2,2$ & $3,0,0,0$ & $6,5,4,3$ \\
\hline sulensis & cyl & 1.0:1 & $1.0: 1$ & $4,3,2,2$ & $3,1,0,0$ & $6,5,4,3$ \\
\hline
\end{tabular}


I. Bartsch

\begin{tabular}{|c|c|c|c|c|}
\hline $\begin{array}{l}\text { species/ } \\
\text { character }\end{array}$ & & legs & & \\
\hline Lohmannella & $\begin{array}{l}\text { bipectinate } \\
\text { setae of I-5 } \\
\text { to IV-5 }\end{array}$ & $\begin{array}{l}\text { strong ventral } \\
\text { setae, I-6 to IV-6 } \\
\text { [apical ones } \\
\text { excluded] }\end{array}$ & $\begin{array}{c}\text { tarsus IV, } \\
\text { dorsal } \\
\text { setae }\end{array}$ & special chracters \\
\hline abyssalis & $5,4,1,2$ & $2,2,1,1$ & 3 & wide distance between P-1 \\
\hline africana & $6,4,2,2$ & $1,1,2,1$ & 3 & dorsal plates intensely ornamented \\
\hline andrei & $?, ?, ?, ?$ & $0, ?, ?, ?$ & ? & gnathosomal base with setae \\
\hline antarctica & $6(-7), 3,1-2,3$ & $2,(1-) 2,2,1(-2)$ & 3 & PD with V-shaped porose areola \\
\hline arenaria & $6,2-3,3 ?, 2 ?$ & $1-2,1,1,1$ & 3 & dorsal plates wide \\
\hline beringi & $?, ?, ?, ?$ & $?, ?, ?, ?$ & $?$ & basal part of palps wider than distal part \\
\hline bihamata & $6,3,1 ?, 3 ?$ & $3,2,2,2$ & 3 & fossary setae plumulate; process of claws with tines \\
\hline bispina & $6, ?, ?, ?$ & $?, ?, 2,1$ & $?$ & shaft of claw with inflation \\
\hline consimilis & $6,3,2-3,3$ & $2,2,2,2$ & 3 & PD pyriform \\
\hline $\begin{array}{l}\text { curvimandi- } \\
\text { bulata }\end{array}$ & $6, ?, ?, ?$ & $2, ?, ?, ?$ & $?$ & \\
\hline cvetkovi & $4, ?, ?, ?$ & $2, ?, ?, ?$ & $?$ & \\
\hline cygna & $8,6,6 ?, 6 ?$ & $2,3,3,3$ & 3 & ds- 6 on inner flank of anal plates \\
\hline dictyota & $7-8,3,1,2$ & $2,2,3-4,4$ & 3 & PD more than 1.6 times longer than wide \\
\hline falcata & $(5-) 6,3,1,2$ & $2,1,2,1$ & 4 & tarsus IV with 4 dorsal setae \\
\hline fukushimai & $7,2,3-4,2-3$ & $2-3,2,3-4,2-3$ & 3 & legs long, glp on OC replaced by setae \\
\hline gaussi & $7,3,1,1$ & $2,2,3,2$ & 3 & glp-2 on $\mathrm{AE}$ \\
\hline grandipora & $6,5,4,3-4$ & $1,1,2,1$ & 3 & \\
\hline heptapegoni & $4,3, ?, ?$ & $2,2, ?, ?$ & $?$ & \\
\hline hureaui & $6, ?, ?, ?$ & $?, 1,3,3$ & 3 & fossary setae plumulate; process of claws with tines \\
\hline kerguelensis & $7,3,1,1$ & $2,2,2-3,2-3$ & 3 & \\
\hline kervillei & $6,3,1-2,1-2$ & $1,1,2,1$ & 3 & rostrum and palps short \\
\hline lamellipes & $6, ?, ?, ?$ & $?, ?, ?, ?$ & 3 & legs with lamellae \\
\hline masatierrae & $6, ?, ?, ?$ & $?, ?, ?, ?$ & 3 & \\
\hline multisetosa & $6,3,2-3,2$ & $1,1,2,1$ & 3 & female with enlarged gac and $50-74 \mathrm{pgs}$ \\
\hline multispina & $(5-) 6, ?, ?, ?$ & $?, ?, ?, ?$ & $?$ & ds-4 in pointed posterior angle of $\mathrm{OC}$ \\
\hline njoerdri & $6,3,1,3$ & $2,1,2,1$ & 3 & claws slender \\
\hline norvegica & $6, ?, ?, ?$ & $1,1,2,1$ & $?$ & \\
\hline nudipes & $5,3,2,3$ & $0,0,0,0$ & 3 & tarsi without ventral setae \\
\hline pinggi & $7,3,2,3$ & $2,2,4,2-3$ & 3 & gnathosona less than half the idiosoma \\
\hline rectangulops & $5,3, ?, ?$ & $2,1,2,1$ & 3 & AD bowl-shaped; tibia II short \\
\hline reducta & $4,2,1,2$ & $2,1,2,1$ & 3 & \\
\hline reticulata & $6,3,1,2$ & $1,1(-2), 2,(1-) 2$ & 3 & PD with V-shaped porose areola \\
\hline rustica & $6,3,1,3$ & $1,1(-2), 2,1$ & 4 & IV-6 with 4 dorsal setae \\
\hline septemsetosa & $6-7,4,2,3$ & $2,2,4,3$ & 3 & \\
\hline setosa & $6, ?, ?, ?$ & $?$ & 3 & AD bowl-shaped, longer than PD; ds-1 with pili \\
\hline stammeri & $4,0,0,0$ & $1-2,2,1-2,1$ & 3 & \\
\hline steueri & $5,3,0, ?$ & $2,1,2,1$ & 3 & \\
\hline subfalcata & $6,3,0,2$ & $2,1,2,1$ & 3 & PD short, circular \\
\hline sulensis & $6,3,2,1$ & $2,1,2,1$ & 4 & tarsus IV with 4 dorsal setae \\
\hline
\end{tabular}




\section{SYSTEMATICS}

\section{Diagnosis, annotated list of species and a tabular key}

Lohmannella Trouessart, 1901 (in Trouessart and Neumann, 1901)

Type species: Leptognathus falcatus Hodge, 1863

Diagnosis. Idiosoma. Length 215-560 $\mu \mathrm{m}$. Generally wide and flattened, dorsal and ventral plates large, neither markedly reduced nor fused. $\mathrm{AD}$ rectangular to hexagonal. OC paired, longer than wide, $\mathrm{PD}$ mostly slightly longer than $\mathrm{AD}$. Idiosoma with up to five pairs of gland pores: these may be large, situated on domes; more or less vestigial; or, rarely, replaced by setae. Second pair of gland pores, if present, in marginal or ventromarginal position, within striated integument, on platelets or on AE. Dorsum with six pairs of idiosomatic setae; rarely with up to eight pairs. In the latter case, the setae substitute gland pores. Adanal setae (ds-6) inserted on anal cone. AE mostly with four pairs of ventral setae. PE with one to three dorsal and three ventral setae. Female GA with 4-74 perigenital setae; each genital sclerite with three to four subgenital setae. Male GA with about 30-85 perigenital setae. Most setae arranged in a dense ring around GO, one to five pairs of setae outlying, i.e., situated in the peripheral part of GA. Each genital sclerite with three to four tiny subgenital setae.

Gnathosoma. Generally slender and much longer than wide. Length ratio gnathosoma:idiosoma about 0.5-1.0:1. Gnathosomal base cubiform, rostrum parallel-sided. In the majority of species rostrum slender and distinctly longer than gnathosomal base. Both pairs of maxillary setae on rostrum, generally in its apical half (except for one species). Palps four-segmented, inserted dorsally, i.e., distance between pair of P-1 generally less than, rarely about the same as diameter of P-1. Rarely, pair of P-1 interlocked or fused. Palps slightly surpassing rostrum. P-2 with two dorsal setae; in a few species with one to five cuticular ventral spines (no real spines because alveolus absent). P-3 short, with spur-like process. P-4 with three setae and one medial spur, apically with eupathid setula and spur. P-2 and P-3 dorso-apically with short, scaliform process.

Legs. In the majority of species slender. Genua shorter than adjoining segments. Basifemora I to IV with (1-)2-3, (1-)2-3, 3(-4), (1-)3 setae, respectively. Tibia I with 4-8 strong, often distinctly bipectinate ventral bristles. Tibia II with 3-6 ventral setae, bristle-like and bipectinate or slender and almost smooth. Tibiae III and IV with 2-6 ventral setae each; setae either bristle-like and bipectinate or slender and, if at all, only faintly serrate. Fossa membranes of tarsi small or absent. Tarsus I with three dorsal setae, a dorsolateral solenidion, zero to four bipectinate ventral setae, zero to four ventral eupathidia and a pair of parambulacral setae. Tarsus II with three dorsal setae, dorsal or dorsomedial solenidion, zero to four ventral setae (basal setae bipectinate, distal setae generally smooth), and pair of parambulacral setae. Tarsi III and IV with four and three (to four) dorsal setae, respectively, zero to six ventral, often bipectinate setae, and a pair of parambulacral setae. Claws smooth or with an accessory process; the latter may bear tines. Central sclerite small. Tarsi often with a short, longitudinally divided carpite between tip of tarsus and a central sclerite. The latter without claw-like process.

The morphological characters of adults of each species are summarized in Table 1.

Biology. All presently known life stages, namely larva, proto-, deutonymph and adults, are free-living.

Distribution. Marine species are spread worldwide, from tropical to polar waters, from the low water edge to the deep sea. Records of the known freshwater species are restricted to Europe and the Middle East.

\section{Annotated list of Lohmannella species}

1. Lohmannella abyssalis Bartsch, 2005 (in Bartsch 2005a)

Reference. Lohmannella abyssalis Bartsch 2005a: 38-40, Figs. 22-37 (female, deutonymph).

Depository. SMF.

Type locality. South Atlantic Ocean, off the South Shetland Islands, $60^{\circ} 39^{\prime} \mathrm{S}, 53^{\circ} 57^{\prime} \mathrm{W}$.

Characters (according to Bartsch 2005a). Length of female $385 \mu \mathrm{m}$. AD hexagonal, wider than PD. Pair of ds-2 in lateral margins of AD. OC trapeziform. Anterior margin of $\mathrm{PD}$ truncate, lateral margins arched. Pair of glp-3 near medial margin of OC, glp-4 rather close to lateral margin of PD. Interval between P-1 almost equalling their width (cf. Table 1). Ratio length of leg I:idiosoma about $0.7: 1$. Tibia I with five bipectinate ventral setae. Tarsi I to IV with 4, 4, 4, 3 dorsal and 3, 2, 1,1 stout ventral setae. Two of the three stout ventral setae of tarsus I in basal position, one situated distad to the level of solenidion. Claws smooth.

Remarks. Unique in L. abyssalis is the distance between the $\mathrm{P}-1$, which equals the width of $\mathrm{P}-1$. In other Lohmannella species P-1 are adjacent, interlocked or even fused. 
Distribution. Antarctica: off the South Shetland Islands, extracted from a 2,893 m depth (Bartsch 2005a).

\section{Lohmannella africana Bartsch, 1992}

(in Bartsch 1992a)

Reference. Lohmannella africana Bartsch 1992a: 460-462, Figs. 12-21 (female).

Depository. SMF.

Type locality. Indian Ocean: South Africa, near East London, Gonubie, $32^{\circ} 56^{\prime} \mathrm{S}, 2^{\circ} 01^{\prime} \mathrm{E}$.

Characters (according to Bartsch 1992a). Length of female $378 \mu \mathrm{m}$. Dorsal plates reticulate, $\mathrm{AD}$ hexagonal, $\mathrm{OC}$ trapeziform, PD rectangular, 1.4 times longer than wide. Pair of glp-3 close to medial angle of OC, glp-4 in lateral margin of PD, glp-5 in posterolateral margin. Gnathosoma slender, 0.7 times of idiosomal length. P-2 with one ventral spiniform process. Length of leg I 0.7 times that of idiosoma. Genu and tibia I with four and six bipectinate ventral setae, respectively. Tarsi I to IV with 4, 4, 4, 3 dorsal and 1, 1, 2, 1 bipectinate ventral setae. Claws with accessory process.

Remarks. In size, outline of plates, arrangement of gland pores and chaetotaxy, L. africana most similar to L. grandipora, but the dorsal plates of $L$. africana are distinctly reticulated, whereas in $L$. grandipora such ornamentation is not mentioned, neither in the description nor in the figures.

Distribution. South Africa, near East London. Extracted from a tidal beach with shell fragments (Bartsch 1992a).

\section{Lohmannella andrei (Angelier, 1951)}

References. Porolhomannella andrei Angelier 1951: 505-507, Figs. 1-5 (male); Angelier 1965: 218, 219, Fig. 8 (male).

Lohmannella andrei, Bartsch 1996: 80; Bartsch 2006a: 146, 147, Figs. 5-22:a-d (male).

Depository. MHNT (?).

Type locality. Europe: France, eastern part of the Pyrenees, near Banyuls-sur-Mer $\left(42^{\circ} 29^{\prime} \mathrm{N}, 3^{\circ} 08^{\prime} \mathrm{E}\right)$.

Characters (according to Angelier 1951, 1965). Length of male $360 \mu \mathrm{m}$. OC diamond-shaped. Genital plate rectangular. GO removed from anterior margin of GA by about twice the length of GO. GO with two pairs of external gac. Rostrum and gnathosomal base similar in length. Pair of mxs-1 situated on gnathosomal base. Length of leg I about 0.8 times that of idiosoma. With 2, 4, 0 strong ventral setae on genu, tibia and tarsus I, respectively. Claws without accessory process.

Remarks. Unique in L. andrei is the position of the mxs-1, on the gnathosomal base instead of on the rostrum, e.g., as illustrated in Fig. 3D (Lohmannella bihamata). A re-study is necessary to analyse this character state. Lohmannella andrei is one of the few freshwater species of this primarily marine genus. Other species found in freshwater are: L. curvimandibulata (Petrova, 1969), L. cvetkovi (Petrova, 1965), L. heptapegoni (Petrova, 1966) and L. stammeri Viets, 1939 (in Viets 1939a). These species have, in contrast to $L$. andrei, $1-2$ bipectinate ventral setae on tarsus I.

Both $L$. andrei and the marine-brackish water inhabiting L. nudipes Bartsch, 1977 have no ventral setae on tarsus I. Lohmannella andrei has, in contrast to $L$. nudipes, neither corneae nor spots with eye pigments and the PD bears two pairs (L. andrei) instead of a single pair (L. nudipes) of setae.

More material - preferably from near the type locality - is needed for a detailed study of both females and males.

Distribution. Europe: France, Eastern Pyrenees. Freshwater. Amongst sediment in the Baillaurie River (near Banyuls-sur-Mer) and Tech, Prats de Mollo, 50-700 m a.s.1. (Angelier 1951, 1965).

\section{Lohmannella antarctica Newell, 1984}

References. Lohmannella antarctica Newell 1984: 249, 250, 252, 253, Figs. 708-711 (female, male, deutonymph, protonymph); Bartsch 1993a: 147-149, Fig. 35A-E (female, male); Bartsch 2008a: 56, 57, Fig. 3 (female, deutonymph, protonymph).

Depository. USNMNH.

Type locality. Antarctica: Palmer Peninsula, Anvers Island, $64^{\circ} 47^{\prime} \mathrm{S}, 64^{\circ} 03^{\prime} \mathrm{W}$.

Characters (according to Newell 1984 and Bartsch 1993a, 2008a). Length of females 430 $470 \mu \mathrm{m}$, of males $420-430 \mu \mathrm{m}$. Dorsal plates reticulated and with porose areolae. Porose areola on PD V-shaped; costae of ' $V$ ' more or less extending to the level of glp-4. Pair of glp-3 situated closer to lateral than to medial margin of OC. Pair of ds -5 immediately posterior to glp-4. Length:width ratio of gnathosoma 1:0.6. Basal seta on P-2 in the segment's basal third. Legs slender, distinctly shorter than idiosoma. Genu, tibia and tarsus I with 4, 6, 2 bipectinate ventral setae, respectively.

Remarks. This species is very similar to L. reticulata Viets, 1950: the two species are similar in their general shape, ornamentation, and the outline of porose areolae of the dorsal plates. Also, in both species, the genua and tibiae I have four and six bipectinate ventral setae, respectively. Discriminating characters are in the position of the glp-3, ds-5 and in the shape of gnathosoma. In Lohmannella antarctica, the glp-3 are closer to the lateral than to the 
medial margin of the $\mathrm{OC}$; in L. reticulata, the position is vice versa. In $L$. antarctica, the ds-5 are immediately posterior to the glp- 4 ; in $L$. reticulata, ds- 5 are distinctly posterior to these gland pores. In $L$. antarctica, the rostrum is longer and the position of the basal setae is more apically than in $L$. reticulata.

Distribution. Antarctica: Palmer Peninsula, Anvers Island, off Elephant I., Weddell Sea, Terre Adelie (Pointe Géologie Archipelago), Ross Island (McMurdo Station). Known depth range: from shallow subtidal to a $460 \mathrm{~m}$ depth. Extracted from hapteres of algae and from bryozoans (Newell 1984; Bartsch 1993a, 2008a).

5. Lohmannella arenaria Bartsch, 1993 (in Bartsch 1993b)

Reference. Lohmannella arenaria Bartsch 1993b: 91-93, Fig. 10A-K (female, male, deutonymph).

Depository. WAM.

Type locality. Indian Ocean: Western Australia; Rottnest Island, $32^{\circ} 01^{\prime} \mathrm{S}, 115^{\circ} 27^{\prime} \mathrm{E}$.

Characters (according to Bartsch 1993b). Length of females 241-256 $\mu \mathrm{m}$, of males 215-263 $\mu \mathrm{m}$. Dorsal plates wide, $\mathrm{AD}$ wider than long, $\mathrm{PD}$ widest in anterior third of plate. Surface of plates with faint reticulation formed by epicuticular granules. Pair of ds- 5 almost level with glp-4 but distinctly removed from lateral margins of PD. Palps basally adjacent. P-2 with two ventral spines. Genu and tibia I with two and three pairs of bipectinate ventral setae, respectively.

Remarks. This small-sized species is characterized by the surface structure of the dorsal plates with epicuticular granules arranged in the form of polygons. Two Lohmannella species are similar in length, namely, L. multispina Newell, 1984 and L. setosa Newell, 1984. In both, the outline of the dorsal plates is very different from that of $L$. arenaria; moreover, in L. setosa, the ds-1, ds-2 and the marginal setae on $\mathrm{PE}$ are unusually long and solid, whereas in L. arenaria, these setae are short and delicate.

Distribution. Rottnest Island, Western Australia. Extracted from coarse tidal sediment (Bartsch 1993b).

6. Lohmannella beringi Newell, 1951

References. Lohmannella falcata beringi Newell 1951: 37 (female).

Lohmannella beringi, Bartsch 2003a: 106.

Depository. AMNHNY.

Type locality. North Pacific Ocean: Attu Island, NE of Alexai Point $\left(52^{\circ} 48^{\prime} \mathrm{N}, 173^{\circ} 18^{\prime} \mathrm{E}\right)$ (holotype female).

Characters (according to Newell 1951). Similar to L. falcata, but basal part of palps much heavier
(2.25 times) than distal part. Length of P-2 3.4 times that of P-4. Claws with delicate accessory tooth.

Remarks. Newell (1951) introduced the name Lohmannella falcata beringi for the North Pacific and the Arctic Ocean specimens, similar to (but obviously not identical with) L. falcata. The specimens were never described in detail. Bartsch (2003a) raised the subspecies to the rank of a species based on the shape of the palps.

Distribution. North Pacific Ocean: Attu Island, St Paul Island and adjacent Arctic Ocean (ca. 52$\left.71^{\circ} \mathrm{N}, 173^{\circ} \mathrm{E}-160^{\circ} \mathrm{W}\right)$. Tidal to subtidal; sand, gravel, calcareous algae (Newell 1951). Records of L. falcata from the Bering Sea and the Kuril Islands (Makarova 1977, 1978) may be representatives of L. beringi (Bartsch 2003a).

\section{Lohmannella bihamata Viets, 1950}

(Figs. 2A-F and 3A-D)

Reference. Lohmannella bihamata Viets 1950, 33-35, Fig. 11A-D (male); Bartsch: present paper, Figs. 2A-F, 3A-D (female).

Depository. Holotype male: NRS. Paratype female: $\mathrm{ZMH}$.

Type locality. South Atlantic Ocean: Falkland Islands, Berkeley Sound, $51^{\circ} 33^{\prime} \mathrm{S}, 58^{\circ} 00^{\prime} \mathrm{W}$.

Characters (according to Viets 1950, as well as to the author's studies of the type material from the Falkland Islands and of a male from South Georgia). Length of males $500 \mu \mathrm{m}$ (holotype and male from South Georgia). Surface of dorsal plates granulated and very delicately reticulated. AD about as long as wide; its posterior part semi-circular. OC with cornea; pair of glp-3 distinct, situated close to lateral margin. PD somewhat longer than AD (male, Viets 1950), or both plates similar in length (female, see below). PD almost rectangular, anterior and lateral margins truncate; L:W ratio of PD 1.3(female)-1.4(male):1. Pairs of glp4 and glp-5 distinct; both close to lateral margins of PD. Pairs of ds- 1 and ds- 3 longer than ds-2, ds- 4 and ds-5. Pair of ds- 5 just posterior to glp-4. Anterior margin of GA arched. About 75 pgs densely arranged around GO; six peripheral pgs near margins of plate, another pair of peripheral pgs halfway between GO and anterior margin of GA. Distance between anterior margin of GO and that of GA equalling 1.2-1.3 times the length of GO. Length ratio gnathosoma:idiosoma about 0.6:1. Rostrum almost as long as gnathosomal base. Distal half of P-2 slenderer than basal part. Genu and tibia I ventrally with three and six bipectinate setae, respectively; tibia II with five (?) ventral setae. 
Description of paratype female:

Locality. South Atlantic Ocean: Falkland Islands, Berkeley Sound, $51^{\circ} 33^{\prime} \mathrm{S}, 58^{\circ} 00^{\prime} \mathrm{W}, 3$ Nov. 1902. ZMH, Viets collection, slide $\mathrm{nr} 7220$ (slide labelled Lohmannella reticulata).

Characters. Length of idiosoma $410 \mu \mathrm{m}$. Length of AD $145 \mu \mathrm{m}$, width $162 \mu \mathrm{m}$. AD bowlshaped, posterior margin semi-circular. OC trapeziform; its length $100 \mu \mathrm{m}$, width $52 \mu \mathrm{m}$. PD rectangular, with slightly concave anterior margin and truncate lateral margins, the latter almost equally distanced throughout their length. Length and width of PD 150 and $117 \mu \mathrm{m}$, respectively; L:W ratio 1.3:1. Pair of ds-1 long, ds-3 broken; setae ds-2, ds-4 and ds-5 short. Gland pores distinct (Fig. 2A and B). Pair of glp-1 on AD, at 0.2 and almost at the level of ds-1. Pair of glp-2 on elongate ventromarginal sclerites. Pair of glp- 3 on OC, at 0.6 of length of $\mathrm{OC}$, situated near lateral margin. Pairs of glp-4 and glp-5 close to lateral margins of PD; glp4 at 0.2 and somewhat anterior to ds-5. Pair of glp-5 in posterior corners of PD. Distance between glp-5 equalling 0.6 times width of PD. Ratio length:width of AE 137:304 $\mu \mathrm{m}$, i.e., length 0.5 times the width; AE with four pairs of setae. GA octagonal to oviform, lateral margins straight and almost equally distanced, middle part of anterior margin truncate (Fig. 2B). Length:width of GA 190:120 $\mu$ m, i.e., length 1.6 times the width. Length of GO $75 \mu \mathrm{m}$. Distance between anterior margin of GO and that of GA somewhat shorter than length of GO. GA with 21 perigenital setae; anterior pair adjacent to anterior margin of GA.

Length of gnathosoma $245 \mu \mathrm{m}$, i.e., 0.6 times length of idiosoma. Length of rostrum $121 \mu \mathrm{m}$. Basal seta on rostrum at 0.6 , that on $\mathrm{P}-2$ at 0.3 (Fig. 3D). Length of P-1 to P-4 38, 112, 11, $38 \mu \mathrm{m}$, respectively. P-2 2.9 times longer than P-4. Length of P-2 about 5.5 times its basal width.

Length of leg I $275 \mu \mathrm{m}$, i.e., 0.6 times that of idiosoma. Genua I to IV with $3 / 5,3 / 5,1 / 3,1 / 3$ ventral/dorsal setae and tibiae I to IV with $6 / 7,4 / 7$, $3 / 4,4 / 4$ ventral/dorsal setae, respectively (Fig. $2 \mathrm{C}-\mathrm{F})$. Ventral setae on genu and tibia I coarsely bipectinate. Each of telofemora I to III with a long and slender dorsal seta; all other setae strong and short. Similarly, one of dorsal setae on genua and tibiae I to III long and slender. All tarsi with small fossary membranes. Tarsi I and II each with three dorsal setae (fossary setae) and a short solenidion. Medial one of apical fossary setae plumulate; lateral fossary seta slender and somewhat longer than medial seta (Fig. 3A and B). Tarsi III and IV with four and three dorsal setae, respectively. Both apical fossary setae of these tarsi plumulate. Second dorsal seta (counted from the basis) of tarsus III slender, shorter than basal seta and with smooth surface (Fig. 3C). All tarsal claws apically with accessory process; this process with about eight tines.

Remarks. Lohmannella bihamata, with large areas of striated, flexible integument between the dorsal and ventral plates, is similar to L. hureaui Newell, 1984 (Kerguelen Islands, 49º S), L. rectangulops Newell, 1984 (Valparaiso, $33^{\circ} \mathrm{S}$ ) and L. setosa Newell, 1984 (San Felix Island, 26ㅇ) Lohmannella bihamata and L. hureaui share the following characters: AD bowl-shaped; glp-1 and ds- 1 situated at almost the same level; glp-3 close to lateral margin of OC; PD almost rectangular and with a truncate or slightly concave anterior margin and straight lateral margins; anterior margin of male GA arched to rounded; dorsomedial fossary seta of tarsi I and II as well as both dorsomedial and dorsolateral setae of tarsi III and IV plumulate. The difference between the females of L. bihamata (from the Falklands) and L. hureaui (from the Kerguelen Islands) is in the length:width ratio of the PD, namely 1.3:1 vs. 1.6:1, respectively. The difference between the males from the Falkland Islands, South Georgia (L. bihamata) and from the Kerguelen Islands ( $L$. hureaui) is in the ratio of the interval between $\mathrm{GO}$ and the anterior margin of GA in respect to the length of GO, namely, 1.3, 1.2 and 1.1 times the length of GO. These differences may be due to distortion of the mounted individuals. Once more material is available for study, $L$. hureaui may turn out to be a junior synonym of $L$. bihamata.

Lohmannella rectangulops can be separated from the two aforementioned species on the basis of: the position of ds-1 (distinctly anterior to vs. almost levelling glp-1); the position of glp-3 (near the medial vs. near the lateral margin of OC); the number of bipectinate setae on tibia I (five vs. six); and the number of plumulate fossary setae (none vs. one to two). Lohmannella setosa is distinguished from the other species by the ds-1, ds- 3 and the marginal setae on PE being longer and stouter.

The paratype female of L. bihamata is smaller than the holotype male from the same area namely, length 410 vs. $500 \mu \mathrm{m}$. Also, the paratype female's telofemora are wider: $\mathrm{L}: \mathrm{H}$ ratio of telofemora I and II are 1.7 and 1.6:1 in the paratype female (vs. 1.9:1 in both telofemora of the holotype male). Differences in L:H values are common due to the deformation in a mounted mite. Additional studies of new material are needed to decide if the difference 


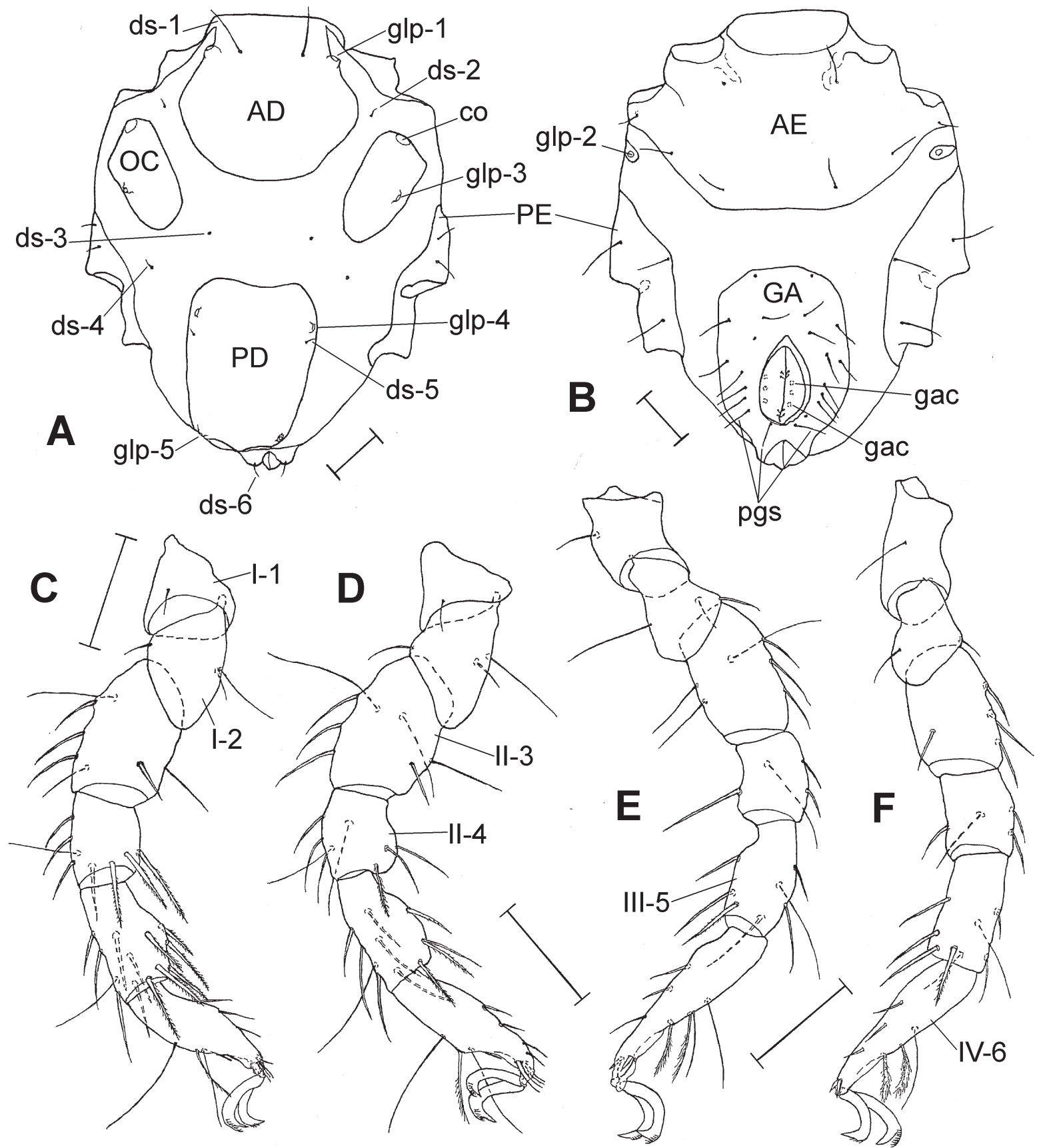

Fig. 2. Lohmannella bihamata Viets, 1950, female. A-idiosoma, dorsal aspect; B - idiosoma, ventral aspect; C-leg I, medial aspect; D, leg II-medial aspect; E-leg III, medial aspect (trochanter somewhat compressed); F-leg IV, medial aspect. Scale $=50 \mu \mathrm{m}$. (AD, anterior dorsal plate; AE, anterior epimeral plate; co, cornea; ds- 1 , ds- 2 , first and second dorsal idiosomatic setae; ds-3, position of third dorsal setae (setae broken); ds-4 to ds-6 fourth to sixth dorsal idiosomatic setae; GA, genitoanal plate; gac, genital acetabulum; glp-1—glp-5, gland pores 1 to 5; OC, ocular plate; PD, posterior dorsal plate; PE, posterior epimeral plate; pgs, perigenital setae; I-1, I-2, trochanter, basifemur of leg I; II-3, II-4, telofemur, genu of leg II; III-5, tibia of leg III; IV-6, tarsus of leg IV).

in body length is within the 'normal' size range and whether the L:H ratio of the telofemora is the result of compression and orientation within the mounting medium or a case of dimorphism. At present, there is a single documented instance of a marked difference between females and males in regards to the shape of the telofemora, namely, that of the halacarid Phacacarus flavellus Bartsch, 1992 (Bartsch 1992b, 1994).

Distribution. South Atlantic Ocean: Falkland Islands and South Georgia. Extracted from tidal and subtidal (16 $\mathrm{m}$ depth) substrata, from sediment 


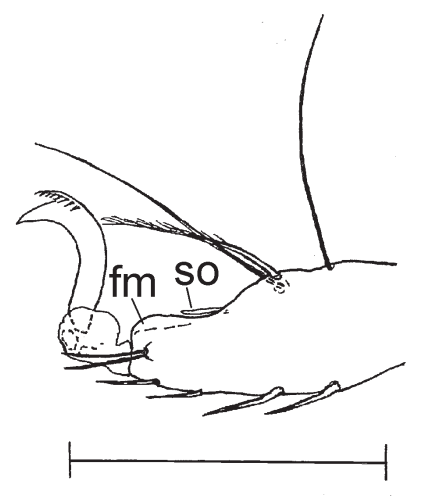

A
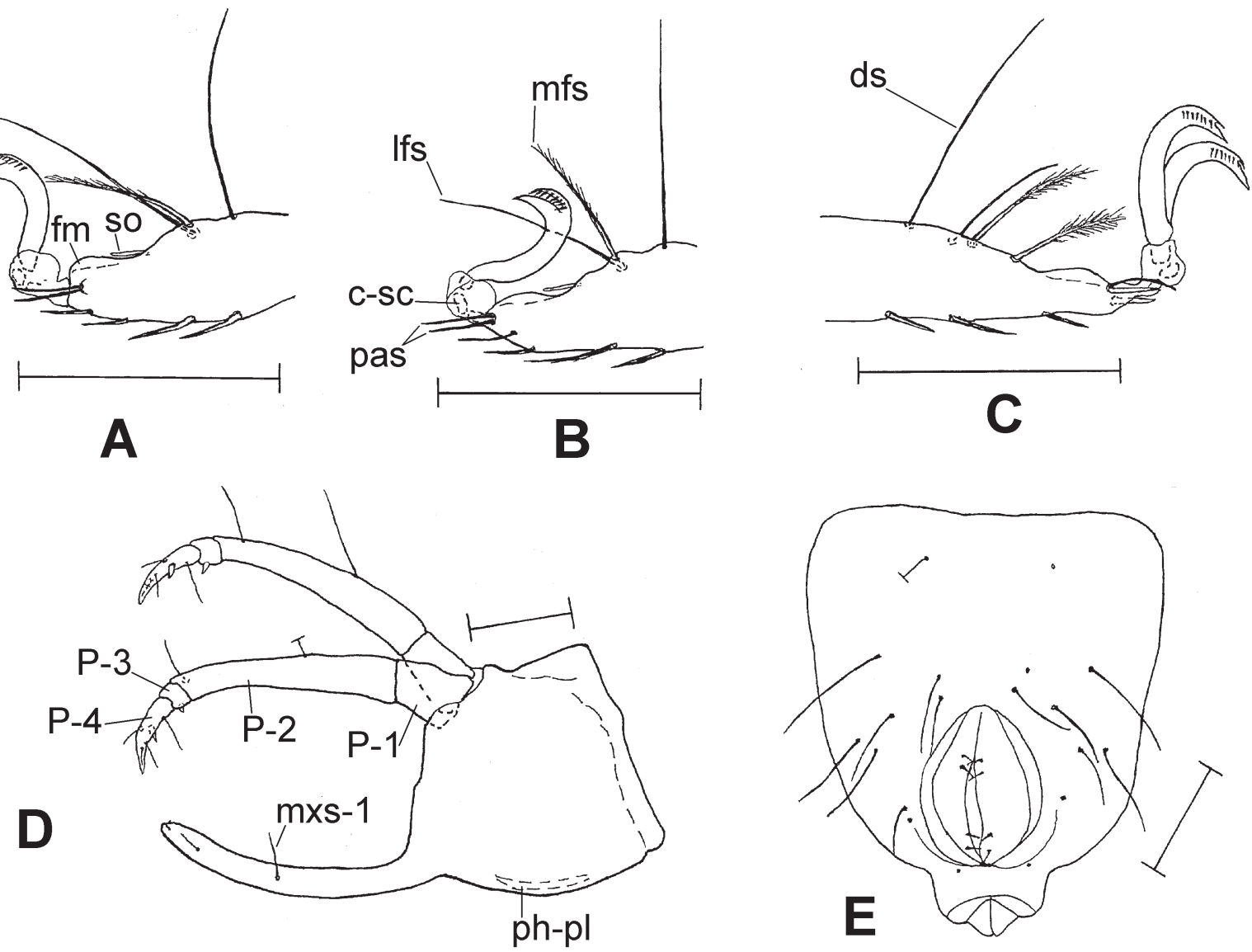

Fig. 3. A-E, Lohmannella bihamata Viets, 1950, female. A-distal part of tarsus I, medial aspect (dorsolateral solenidion illustrated, lateral claw and parambulacral setae omitted); B-distal part of tarsus II, medial aspect (lateral claw and parambulacral setae omitted); C-distal part of tarsus III, medial aspect; D-gnathosoma, lateral aspect; E-Lohmannella reticulata Viets, 1950, female, genitoanal plate. Scale $=50 \mu \mathrm{m}$. (c-sc - central sclerite; ds, dorsal fossary seta; fm, fossary membrane; lfs, lateral fossary seta; mfs, medial fossary seta; mxs-1, basal maxillary seta; pas, doublet of parambulacral setae; ph-pl, pharyngeal plate; P-1 to P-4, first to fourth palpal segment); so, solenidion).

and kelp holdfasts (Viets 1950; Pugh and Bartsch 1994). Lohmannella hureaui, which may be synonymous with $L$. bihamata, has been extracted from the holdfasts of algae growing on the coast of the Kerguelen Islands.

\section{Lohmannella bispina Newell, 1984}

Reference. Lohmannella bispina Newell 1984: 252, 258, 260, 261, Figs. 741-746 (female, male).

Depository. USNMNH.

Type locality. South Pacific Ocean: Chile, Fuerto Bulnes, ca. $57 \mathrm{~km} \mathrm{SW}$ of Punta Arenas (ca. $53^{\circ} 37^{\prime} \mathrm{S}, 70^{\circ} 56^{\prime} \mathrm{W}$ ).

Characters (according to Newell 1984). Length of females 395-425 $\mu \mathrm{m}$. Lateral margins of AD slightly diverging, posterior margin wide, arched. OC trapeziform. PD rectangular, ratio L:W 1.3:1. Pair of glp-3 in medial corner of OC, glp-4 near lateral margin of PD. P-2 with two ventral spines. Tibia I with six bipectinate ventral setae. Shaft of claws with dorsal bulging (Newell 1984: Figs. 742, 744).
Remarks. Differences between this species and the very similar L. grandipora are, according to Newell (1984), the following: P-2 stouter, glp-2 in more ventral position and their diameter smaller. The shape of the claws of L. grandipora is not described.

Distribution. South Pacific Ocean: southern Chile, Fuerto Bulnes SW of Punta Arenas. Extracted from very coarse sediment, from the low mid tide zone (Newell 1984).

\section{Lohmannella consimilis Bartsch, 1993}

(in Bartsch 1993a)

Reference. Lohmannella consimilis Bartsch 1993a: 150-153, Figs. 58A-D, 59A-E (female).

Depository. USNMNH.

Type locality. Antarctica: South Sandwich Islands, $46^{\circ} 42^{\prime} \mathrm{S}, 27^{\circ} 00^{\prime} \mathrm{W}$.

Characters (according to Bartsch 1993a). Length of female $385 \mu \mathrm{m}$. Surface of dorsal plates almost smooth, except for a pair of porose areolae 
in margin of PE, anterior to insertion of leg III. OC with cornea. Distance between pair of glp-3 and lateral margin of $\mathrm{OC}$ equalling $1 / 5^{\text {th }}$ of largest width of OC. PD pyriform; widest at 0.3 ; lateral margins of anterior part of PD arched. Pair of glp-4 removed from lateral margins. P-2 with slightly convex ventral margin. Genu, tibia and tarsus I with four, six and two bipectinate ventral setae, respectively.

Remarks. Rather unique is the pyriform PD and the slightly convex ventral margin of P-2. A somewhat similarly shaped PD is found in Lohmannella kerguelensis (Lohmann, 1907 (in Lohmann 1907b) and L. fukushimai Imamura, 1968. However, the above two species are larger than L. consimilis; their ds- 1 are not anterior to the glp-1 (as in L. consimilis) but at about the same level; their palps are longer; and their tibia I has seven bipectinate ventral setae (vs. six in L. consimilis). Moreover, L. fukushimai is characterized by a prolonged anal cone (vs. rather short anal cone in the other two species).

Distribution. Antarctica: South Sandwich Islands; extracted from about $100 \mathrm{~m}$ depth (Bartsch 1993a).

10. Lohmannella curvimandibulata (Petrova, 1969)

References. Porolohmannella curvimandibulata Petrova 1969: 103-105, Figs. 4a, b, 5a, b, 6a-d (female, male).

Lohmannella curvimandibulata, Bartsch 1996: 81; Bartsch 2006a: 147, 148, Fig. 5-23a-d.

Depository. NMNHS.

Type locality. Europe: north-eastern Bulgaria, district Rousse (Ruse), Village of Polsko Kosovo, $43^{\circ} 25^{\prime} \mathrm{N}, 25^{\circ} 39^{\prime} \mathrm{E}$.

Characters (according to Petrova 1969). Length of female $420 \mu \mathrm{m}$, of male $390 \mu \mathrm{m}$. PD of male slenderer than that of female. Surface of dorsal plates reticulated. OC rather slender, triangular, obliquely positioned, posteriorly pointed. Each OC with ds-2 but without cornea. PD rectangular. Male GA with about 42 pgs close around GO and four outlying setae in anterior part of GA. Genital sclerites of female with two pairs, those of males with three pairs of acetabula, these situated adjacent in posterior part of GO. P-2 with convex ventral and almost straight to slightly concave dorsal margin. Telofemur I with one long ventral seta; genu, tibia and tarsus I with four, six and two bipectinate ventral setae, respectively. One of dorsal setae on tibia I bipectinate.

Remarks. Lohmannella curvimandibulata is an inhabitant of freshwater and is most similar to
L. cvetkovi, L. heptapegoni and L. stammeri. These species share the following characters: OC elongate-triangular, without cornea but with one seta in anterior part, tarsus I with one or two bipectinate ventral setae.

According to Fig. 6d in Petrova (1966), genu I of L. curvimandibulata bears four, and tibia I six, ventral setae; this combination is shared with L. cvetkovi (see below). The genua and tibiae I of L. heptapegoni and L. stammeri have three and four ventral setae, respectively.

Distribution. Europe: Freshwater; Bulgaria, district Rousse (Ruse), Polsko Kosovo (Petrova 1969).

\section{Lohmannella cvetkovi (Petrova, 1965)}

References. Porolohmannella cvetkovi Petrova 1965: 338; Petrova 1969: 100-103, Figs. 1a, b, 2a, b, 3a-d (female, male); Petrova et al. 1991.

Porolohmannella cvetkovi thracicus Petrova et al., 1991: 10.

Lohmannella cvetkovi, Bartsch 1996: 81; Bartsch 2006a: 148, 149, Fig. 5-24a-e.

Depository. NMNHS.

Type locality. Europe: South Bulgaria, district Haskovo, Village Šišmanovo, about $42^{\circ} 02^{\prime} \mathrm{N}$, $25^{\circ} 53^{\prime} \mathrm{E}$.

Characters (according to Petrova 1965 and 1969). Length of female $318 \mu \mathrm{m}$, of male 324 $408 \mu \mathrm{m}$. AD and PD of male wider than these plates in female. Surface of dorsal plates reticulated. OC posteriorly acuminate; general shape like that of an inverted drop, arranged obliquely; each plate with a seta (ds-2). Neither cornea nor eye pigment present. PD rectangular, with pair of gland pores in posterior part. Both females and males with external gac. Male GA with about 40 pgs close around GO and four outlying setae in anterior part of GA. Genital sclerites of female with two pairs of acetabula near end of genital slit; males with three pairs of acetabula situated adjacent in posterior part of GO. P-2 nearly straight. Telofemur, genu, tibia and tarsus I with 2, 4, 6, 2 stout ventral setae, respectively. Two setae on tibia I slender, the other setae wider and pectinate. One of dorsal setae on each genu and tibia I bipectinate.

Remarks. Lohmannella cvetkovi shares several characters with the above outlined freshwater species L. curvimandibulata: the shape of the dorsal and ventral plates is almost the same, so is the number and arrangement of setae on leg I. The two species differ in the following: telofemur I of L. curvimandibulata has ventrally one long, smooth seta but $L$. cvetkovi has two strong, bipectinate 
setae. In regards to the given difference in the position of dorsal setae and gland pores, misinterpretation cannot be excluded. A careful re-examination is recommended, and L. curvimandibulata may turn out to be a junior synonym of $L$. cvetkovi.

Distribution. Europe: West Bulgaria, ZlaticaPirdop Basin; South to North Bulgaria, district Haskovo, Village Šišmanovo; Stara Zagora; Tarnovo, Village Polikraište (Petrova 1965, 1969).

\section{Lohmannella cygna Bartsch, 1988}

Reference. Lohmannella cygna Bartsch 1988: 818, 819, Figs. 1-10 (female).

Depository. USNMNH.

Type locality. South Atlantic Ocean: Angola Basin, $9^{\circ} \mathrm{S}, 12^{\circ} \mathrm{E}, 1,427-1,643 \mathrm{~m}$ deep.

Characters (according to Bartsch 1988). Length of female $515 \mu \mathrm{m}$. AD much wider than long. PD pear-shaped, widest in anterior third of plate. Pair of glp-1 on slightly raised cones, following gland pores rather small, not on cones. Pairs of ds-5 and glp-4 both situated close together and distinctly removed from lateral margins of $P D$. PE with 3/3 dorsal/ventral setae. GA rectangular. Anal cone prolonged, medial flank of anal sclerites with a pair of minute processes (nipper forceps) and, immediately adjacent, with minute ds-6. Gnathosoma slender, only slightly shorter than idiosoma. Slender palps somewhat curved. Legs slender, length of leg I about 0.8 of that of idiosoma. Genu I with five and tibia I with eight bipectinate ventral bristles.

Remarks. The most obvious characters of Lohmannella cygna are: gnathosoma and legs long and slender, anal cone ending with tiny nippers, ds -5 and glp-4 situated close together; tibia I with eight bipectinate ventral bristles. Lohmannella cygna is similar to L. fukushimai in habitus, but in the latter species the glp- 4 are replaced by small setae, the ds- 6 are on the lateral flanks of the anal cone, and the surface of the dorsal plates is not smooth, as in L. cygna, but covered with a delicate epicuticular granulation.

An individual from the south-western Pacific Ocean, North Fiji Basin $\left(17^{\circ} \mathrm{S}, 174^{\circ} \mathrm{W}\right), 2,000 \mathrm{~m}$ depth, collected in the course of the French-Japanese project STARMER II Cruise, contained a female, $560 \mu \mathrm{m}$ in length, which strongly resembles the above diagnosed L. cygna. Its characters are outlined below (Lohmannella sp. C). The difference in the number of bipectinate ventral setae on genu and tibia I (five and eight in L. cygna, but four to five and seven in the specimen from the North Fiji Basin) is within the range of variation found in other species. The individual from the North Fiji Basin may be conspecific with L. cygna .

Distribution. South Atlantic Ocean: Angola Basin, $9^{\circ} \mathrm{S}, 12^{\circ} \mathrm{E}$, dredged with an epibenthic sled at about 1427-1643 $\mathrm{m}$ depth (Bartsch 1988). In case the individual from the North Fiji Basin is conspecific with L. cygna, the range of distribution has to be extended to the south-western Pacific Ocean.

\section{Lohmannella dictyota Bartsch, 1992}

Reference. Lohmannella dictyota Bartsch 1992a: 458-460, Figs. 1-11 (female).

Depository. SMF.

Type locality. South Pacific Ocean: Society Islands, Bora Bora, reef area near Vaitape; about $16^{\circ} 30^{\prime} \mathrm{S}, 151^{\circ} 45^{\prime} \mathrm{W}$.

Characters (according to Bartsch 1992a). Length of female $375 \mu \mathrm{m}$. Dorsal and ventral plates reticulate. PD long (L:W 1.7:1) with porose median areola in posterior half. Porus of glp- 1 within raised cone. Pair of P-1 fused. P-2 with ventral spine. Legs short, 0.8 times idiosomal length. AE and PE with articular membranes flanking bases of trochanters. Genua I with three ventral setae, the two medial ones bipectinate. Tibia I with seven to eight bipectinate ventral setae. Tarsi I to IV with 4 , 4, 4, 3 dorsal and 4, 4, 4, 4 ventral setae; of the ventral setae 2, 2, 3, 3 setae bipectinate.

Remarks. Amongst the presently known Lohmannella species, L. dictyota is the only one which has the pair of P-1 fused.

Distribution. South Pacific Ocean: Society Islands, Bora Bora $\left(16^{\circ} \mathrm{S}, 152^{\circ} \mathrm{W}\right)$, reef area near Vaitape, $0.5-1 \mathrm{~m}$ depth, coral fragments coated by algae and sponges; north-eastern Australia, Great Barrier Reef $\left(14-19^{\circ} \mathrm{S}, 145-149^{\circ} \mathrm{E}\right)$ and Coral Sea $\left(17^{\circ} \mathrm{S}\right.$, $\left.151^{\circ} \mathrm{E}\right)$, amongst shallow water $(2-17 \mathrm{~m}$ depth) coarse sand and rubble (Bartsch 1992a; Otto 2000).

\section{Lohmannella falcata (Hodge, 1863)}

References. Leptognathus falcatus Hodge 1863: 302, 303, Figs. 6 and 7.

Lohmannella falcata, Trouessart 1901: 250 (in Trouessart and Neumann 1901); Viets 1927a: 29, Figs. 71, 72) (female, male); Fountain 1953: 363, 364, Fig. 3 (female); Newell 1947: 190, 191, Figs. 327-330 (male); Bartsch 1972: 218 (female, male, deutonymph, protonymph); Bartsch 1977: 142, 143, 152, Figs. 1-9 (female, male); Bartsch 1979a: 57 (female, male, deutonymph, protonymph); Green and MacQuitty 1987: 140, 141, Fig. 57A-D.

Depository. Holotype female, Hancock Museum, New-Castle-upon-Tyne, UK. 
Type locality. North Sea: Great Britain, Seaham Harbour (ca. $54^{\circ} 50^{\prime} \mathrm{N}, 1^{\circ} 21^{\prime} \mathrm{W}$ ), 20-30 fathom (35-55 m).

Characters (according to Fountain 1953; Bartsch 1977; Green and MacQuitty 1987). Length of females 270(?)-515 $\mu \mathrm{m}$, of males 335-490 $\mu \mathrm{m}$. Length of holotype female ca. $430 \mu \mathrm{m}$. AD hexagonal, slightly wider than long. OC trapeziform, posterior part of plate wider than anterior one. PD slightly pyriform, widest at the level with insertion of leg III; anterior margin of PD arched, lateral margins posteriad convergent. Gland pores vestigial. Female GA longer than wide; its anterior margin arched. Length ratio gnathosoma:idiosoma about $0.5-0.6: 1$. Length of leg I about 0.7 times that of idiosoma (Hodge 1863: Fig. 6; Fountain 1953: Fig. 3). Genu and tibia I with four and (five to) six bipectinate ventral setae, respectively. Tarsi III and IV with four dorsal setae each. Claws with minute accessory process.

Remarks. Lohmannella falcata is one of the few species with four dorsal setae on tarsi III and IV, whereas the majority of Lohmannella species have four dorsal setae on tarsus III but solely three on tarsus IV. Other species with four dorsal setae on tarsus IV are L. rustica Bartsch, 1977 and L. sulensis Bartsch, 2020. Since the number of dorsal setae on tarsus IV is not given in all descriptions, more Lohmannella species may have that number of setae. Lohmannella rustica is smaller: its length is $273-335 \mu \mathrm{m}$. L. sulensis has a remarkably wide AD: its width is 1.5 times the length.

Since the first description of Lohmannella falcata is far from detailed, we can expect a number of misidentifications. A new detailed description is needed, if possible, on the basis of specimens collected near the type locality, presenting both morphological and molecular data.

Distribution. North-western Atlantic Ocean: Canada, New Brunswick; USA, Rhode Island. North-eastern Atlantic Ocean (North and White Sea included): Denmark, France, Germany, Iceland, Jan Mayen Ridge (record cited as Lohmannella sp., Fricke et al. 1989), Norway, Republic of Ireland, Russia, Spain, the Netherlands, UK (England, Northern Ireland, Scotland, Wales) (Viets 1956; Motaş 1961; Green and MacQuitty 1987; Somerfield 1988; Bartsch and Smit 2006; Krivolutsky and Antsiferova 2008; Riesgo et al. 2010). The Mediterranean and Black Sea: Croatia, France, Italy, Monaco, Spain, Bulgaria, Crimea, Romania, Russia (Caucasian coast), Turkey, Ukraine (Viets
1956, Pešić 2004; Bartsch 2004a; Durucan 2018; Martinez et al. 2021). Baltic: Denmark, Estonia, Finland, Germany, Latvia, Poland, Russia, Sweden (Lohmann 1893; Sokolov 1952; Viets 1956; Jarvekjul 1979). Lohmannella falcata is also found in brackish water areas, in the Baltic, at 6-7 S\%o (Lohmann 1907a; Kautsky 1974). Records from the inner parts of the Gulf of Bothnia and the Gulf of Finland (Svenonius 1949; Sokolov 1952) - areas with a salinity of 2.5-3.5 S\% - may be ones of Porolohmannella violacea (Kramer, 1879). According to Kautsky et al. (1981) and according to the specimens identified by the author of this paper, $P$. violacea but not $L$. falcata occurs in the inner part of the Gulf of Bothnia.

Lohmannella falcata has been extracted from hydrozoans, bryozoans, algae, sediment, from the low water edge to constantly submersed zones. The deep-water records from the Bay of Biscay, from the depths of 400-500 $\mathrm{m}$ and 1,410 m, most likely do not belong to L. falcata (Trouessart and Neumann 1896).

15. Lohmannella fukushimai Imamura, 1968

References. Lohmannella fukushimai Imamura 1968: 472-475, pl. 1: Figs. 1-4, pl. 2, Figs. 1-5 (male, deutonymph); Bartsch 1993a: 153-155, Fig. 60A-E (female, male); Bartsch 2010a: 168 (female, male); Bartsch 2016: 143, Fig. 3F, G (female, male, deutonymph).

Depository. NSMT (Japanese Antarctic Expedition, NIPR).

Type locality. Antarctica: off Princess Ragnhild Coast/Prince Harald Coast, $69^{\circ} \mathrm{S}, 31^{\circ} \mathrm{E}, 190 \mathrm{~m}$ depth.

Description (according to Imamura 1968 and Bartsch 1993a, 2010a; 2016). Length of females 495-560 $\mu \mathrm{m}$, of males 491-582 $\mu \mathrm{m}$. Idiosoma with prolonged anal cone. Dorsal plates with small epicuticular papillae. Each OC with eye pigment, one distinct and one small cornea. Pairs of glp-3 and glp-4 replaced by minute setae. Gnathosoma slender, almost as long as idiosoma. Legs slender, slightly longer than idiosoma. Genu, tibia and tarsus I with $4(-6), 7(-8), 2-3$ pectinate ventral bristles. Tibiae II to IV with $6,6,5$ ventral bristles, $2,3-4,2-3$ of these setae bipectinate, tarsi II to IV with 2, 3-4, 2-3 solid ventral setae. Each tarsal claw with minute accessory process.

Remarks. The species is characterized by its long anal cone, gnathosoma and legs, the length of the legs is about the same as that of the idiosoma. An unusual feature of this species is that some of the gland pores are replaced by minute setae. 
The descriptions in Imamura (1968) and Bartsch (1993a) show minor differences, e.g., in respect to the gland pores. According to Imamura (1968), each OC has a gland pore (glp-3) and, immediately adjacent, a seta; the glp-4 (on the PD) are represented by minute pores. However, according to Bartsch (1993a), both glp-3 and glp-4 are replaced by delicate setae. Moreover, according to Imamura (1968), both $\mathrm{AD}$ and $\mathrm{PD}$ are similar in width, whereas in the individual illustrated in Bartsch (1993a), the AD is wider than the PD. Such differences may be within the normal range of variants, be the result of handling during the mounting process, but may also hint at the fact that the individuals studied belong to similar but distinct species.

Distribution. Southern Oceans: CircumAntarctic with records from the Weddell Sea, off Prince Harald Coast, the Ross Sea and the Amundsen Sea. Present depth range extends from about 190 to 1047 m (Imamura 1968; Bartsch 1993a, 2010a, 2016).

16. Lohmannella gaussi Lohmann, 1907 (in Lohmann 1907a)

References. Lohmannella gaussi Lohmann 1907a: 19, 20; Lohmann 1907b: 391, 392, pl. 42, Figs. 1, 3, 5-7 (female); Bartsch 1979b: 334-338, Figs. 26-43 (female, male, deutonymph); Bartsch 2016: 144, Fig. 3H; Newell 1984 (L. humerosa): 250-253, Figs. 712-716 (female, male).

Type locality. Antarctica: GAUSS Station, off Wilhelm II Land, $66^{\circ} 02^{\prime} \mathrm{S}, 8^{\circ} 38^{\prime} \mathrm{E}$.

Depository. MNHUB. A slide of a female labelled Lohmannella gaussi Lohm, Lohm. det., Antarktis. D-Südpol.-Exped. 4.4.1902, is housed in the ZMH. Lohmannella humerosa is in USNMNH.

Characters (according to Lohmann 1907b; Bartsch 1979b, 2016). Length of females 431$568 \mu \mathrm{m}$, of males $407-500 \mu \mathrm{m}$. AD, OC, PD, AE, and $\mathrm{PE}$ with porose areolae; areola on PD V-shaped. OC with one distinct and one faintly developed cornea. Epimera II marginally widened, with porose areolae and glp-2. Gnathosoma long and slender, its length $0.7-0.8$ times that of idiosoma. Genu I with four bipectinate ventral setae, tibiae I to IV with 7 , $6,6,5$ ventral bristles, of these 7, 3, 1, 1 distinctly bipectinate, tarsi I to IV with 2, 2, 3, 2 bipectinate ventral bristles. All tarsi with additional apical setae. Claws with minute accessory process.

Remarks. A character that has not yet been described in any other Lohmannella species, is the presence of the glp-2 on the AE, namely, within the area corresponding to the EII. In deutonymphs, the gland pores are on platelets within the striated integument (Bartsch 1979b: Fig. 37). Also, the deutonymphal AE has four pairs of setae (not three pairs as illustrated by Bartsch 1979b: Fig. 37).

Well demarcated porose areolae, as present in L. gaussi, have been found in a few Pacific and southern hemisphere Lohmannella species. Somewhat similar areolae are present in L. antarctica but that species lacks the median transverse areola on the $\mathrm{AD}$ and the marginal ones on the $\mathrm{AE}$ and $\mathrm{PE}$, moreover the gnathosoma of $L$. antarctica is shorter (gnathosoma:idiosoma length 0.6:1).

Distribution. Circum-Antarctic and sub-Antarctic Seas: Records are from off the South Sandwich Islands (148 m), the Weddell Sea (211 m), the GAUSS Station, off Wilhelm II Land (385 m) and from near the Marion and Crozet Islands $(95 \mathrm{~m}$ ) (Lohmann 1907a, b; Bartsch 1979b, 1993a, 2016; Newell 1984).

\section{Lohmannella grandipora Newell, 1984}

Reference. Lohmannella grandipora Newell 1984: 252, 258-260, Figs. 721-740 (female, male).

Depository. USNMNH.

Type locality. South Pacific Ocean: Chile, ca. $3 \mathrm{~km} \mathrm{NW}$ of Caldera. Punta Caldera, $27^{\circ} 03^{\prime} \mathrm{S}$, $70^{\circ} 52^{\prime} \mathrm{W}$.

Characters (according to Newell 1984 and the author's examination of a female from South Georgia). Length of females and males from southern Chile 390-456 $\mu \mathrm{m}$ and 395-425 $\mu \mathrm{m}$, respectively, of a female from South Georgia $525 \mu \mathrm{m}$. Surface of dorsal plates rather smooth. AD widest in its posterior half; posterior margin of plate arched. OC trapeziform; corneae absent. PD rectangular, 1.4 times longer than wide. Pair of ds-3 in anterior margin of PD. Pair of glp-3 in medial corner of OC, glp-4 near lateral margin of PD. Length of gnathosoma 0.6 times that of idiosoma. P-2 slender, ratio length:diameter $8.0-9.7: 1$; P-2 with one to two ventral spiniform processes. Length of leg I about 0.6 times that of idiosoma. Genu with four bipectinate ventral setae, tibiae I to IV with $6,5,4,3-4$ ventral setae, respectively, all bipectinate; tarsi I to IV with 1, 1, 2, 1 bipectinate ventral setae. Claws with minute accessory process.

Remarks. Lohmannella grandipora is similar to L. africana and L. bispina. In contrast to two other species, the dorsal plates of $L$. africana are markedly reticulated and the ds- 3 are in the striated integument (vs. surface of plates almost smooth and ds-3 on the PD). In L. bispina, the P-2 is stouter (shorter) than in the other two species and 
the shaft of tarsal claws is dorsally not evenly rounded but bulging.

The female from South Georgia (cf. Pugh and Bartsch 1994) has slender palps with a length:width ratio of 7:1; each P-2 has one long and one short spiniform process. The claws are dorsally not evenly rounded, but very, very slightly bulging. According to the description given by Newell (1984), the differences between Lohmannella bispina and L. grandipora are small. Studies on new material, collected along the Pacific and Atlantic Coasts of South America, as well as from South Georgia, from different latitudes and habitats, may prove $L$. bispina to be a junior synonym of $L$. grandipora. In addition, L. grandipora may prove to be a warm water species, with its cold water records, e. g., Punta Arenas, Fuerte Bulnes and South Georgia, actually being those of L. bispina.

Distribution. South Pacific Ocean: southern Chile, Punta Caldera (type locality), Punta Arenas and Fuerte Bulnes. From intertidal sand and coarse shell fragments and amongst kelp holdfast washed up on the beach (Newell 1984). South Atlantic Ocean: South Georgia, Husvik Harbour, under stones (Pugh and Bartsch 1994).

18. Lohmannella heptapegoni Petrova, 1966

References. Porolohmannella heptapegoni Petrova 1966: 359-361, pl. 67, Figs. 1-6 (male).

Lohmannella heptapegoni, Bartsch 1996: 81.

Depository. NMNHS.

Type locality. Asia: Israel, hot, slightly saline springs near Lake Tiberias (Sea of Galilee or Genneseret); about $32^{\circ} 47^{\prime} \mathrm{N}, 35^{\circ} 32^{\prime} \mathrm{E}$.

Characters (according to Petrova 1966). Length of male $318 \mu \mathrm{m}$. Surface of dorsal plates smooth. AD with pair of pores. OC rather slender, obliquely arranged; no cornea but pair of ds-2 present. Pair of ds-4 and ds-5 in anterior half of PD. Male GA ovate, with outlying setae included about 33 pgs. GO with three pairs of external gac, situated adjacent. P-2 with almost straight ventral margin. P-4 short. Genu, tibia and tarsus I with 2, 4, 2 strong ventral setae, respectively.

Remarks. Lohmannella heptapegoni is in dorsal aspect similar to the freshwater Lohmannella species L. andrei, L. curvimandibulata, L. cvetkovi and L. stammeri. Tarsus I of $L$. andrei has no strong ventral setae; the others ( $L$. curvimandibulata, L. cvetkovi, L. heptapegoni and L. stammeri) have one to two wide (bipectinate) ventral setae. The surface of the dorsal plates is reticulated in L. curvimandibulata and L. cvetkovi but smooth in L. hep- tapegoni and L. stammeri. According to Petrova (1966: pl. 67, Fig. 6), there are no ventral setae on telofemur II, whereas in L. stammeri two are present. Most Lohmannella species have ventral setae on telofemur I and the said absence of setae in L. heptapegoni may be a lapsus. Re-examinations of holotypes or individuals from the type localities may prove L. heptapegoni to belong to L. stammeri.

Distribution. Asia, Middle East: Israel. Slightly saline springs near Lake Tiberias (a.k.a. the Sea of Galilee or the Lake of Gennesaret) (Petrova 1966).

19. Lohmannella hureaui Newell, 1984

Reference. Lohmannella hureaui Newell 1984: 252-255, Figs. 717-720 (female, male).

\section{Depository. USNMNH.}

Type locality. Indian Ocean: Kerguelen Islands, north of Ronarc'h Peninsula, Bay of Morbihan, Port Douzième, about $49^{\circ} 30^{\prime} \mathrm{S}, 70^{\circ} 15^{\prime} \mathrm{W}$.

Characters (according to Newell 1984). Length of female $547 \mu \mathrm{m}$. PD rectangular. Pair of glp-3 close to lateral margin of OC, glp-4 close to margin of $\mathrm{PD}$, that latter pair of pores slightly anterior to ds-5. Female and male genital plate elongate-circular; L:W ratio 1.3:1. Tibia I with six bipectinate ventral setae. On tarsi I and II medial one of dorsal fossary setae plumulate, on tarsi III and IV both apical fossary setae plumulate.

Remarks. The character 'plumulate fossary setae' is shared with Lohmannella bihamata. The two species are similar in the outline and chaetotaxy. There are small differences in the shape of the GA: in L. bihamata, the GA of both females and males is slenderer than in L. hureaui. Males of $L$. hureaui have two pairs of outlying pgs, and the holotype male of $L$. bihamata three pairs. As long as it is not proven that these characters are rather variable and the results of measurements of individuals from the southern Indian Ocean and the Atlantic Ocean are overlapping, the individuals should be handled as belonging to two separate species. However, it is likely that the result of the examination of more material from the southern Indian and the Atlantic Oceans will be as follows: L. bihamata is a circum sub-Antarctic species and L. hureaui is its synonym.

Distribution. Indian Ocean: Kerguelen Islands. Holdfasts of kelp (Phaeophyta) (Newell 1984).

20. Lohmannella kerguelensis Lohmann, 1907 (in Lohmann 1907b)

References. Lohmannella gaussi kerguelensis Lohmann 1907b: 392, text Fig. 15 (male); Lohman- 
nella kerguelensis, Bartsch 1993a: 157-159, Fig. $62 \mathrm{~A}-\mathrm{E}$ (male).

Depository. MNHUB (?).

Type locality. Indian Ocean: Kerguelen Islands.

Characters (according to Lohmann 1907b and Bartsch 1993a). Length of males 420-450 $\mu \mathrm{m}$. Dorsal plates with epicuticular granulate and mazelike texture. PD ovate, anterior margin wide, semicircular. Pair of glp-4 somewhat posterior to ds-5 and removed from lateral margin of PD by about four times the diameter of the cones including the glp-4. GA with almost 50 pgs closely arranged around $\mathrm{GO}$ and three pairs of outlying setae. Length ratio gnathosoma:idiosoma about $0.7: 1$. Genu and tibia I with four and seven bipectinate ventral bristles, genua and tibiae II to IV with 4, 1, 1 and 6, 6, 5 ventral bristles, respectively. Tarsi I to IV with 4 , 4, 4, 3 dorsal setae and 2, 2, 2-3, 2-3 ventral bristles.

Remarks. Genu and tibia I have four and seven bipectinate ventral setae, respectively. A similar number is found in L. gaussi and L. fukushimai, but in these two species the gnathosoma:idiosoma length ratio, namely $0.8-1.0: 1$, surpasses that of L. kerguelensis.

Distribution. West Antarctica: Palmer Archipelago, $64^{\circ} \mathrm{S}, 61^{\circ} \mathrm{W}$. Indian Ocean: Kerguelen Islands. Extracted from shallow water algae and from 49-58 m depth (Lohmann 1907b; Bartsch 1993a).

21. Lohmannella kervillei Trouessart, 1894 (in Trouessart and Neumann 1894)

References. Leptognathus Kervillei Trouessart and Neumann 1894: 170, 171, P1. 1, 1a, 1 b (female).

Lohmannella kervillei, Trouessart and Neumann 1901: 264; Bartsch 1977: 143-146, Figs. 10-30 (female, male, juveniles); Green and MacQuitty 1987: 142, 143, Fig. 58A-D (male).

Depository. MNHNP.

Type locality. Eastern North Atlantic Ocean: France, English Channel, Les Chausey $\left(48^{\circ} 52^{\prime} \mathrm{N}\right.$, $\left.1^{\circ} 49^{\prime} \mathrm{E}\right)$.

Characters (according to Trouessart and Neumann 1894 and Bartsch 1977). Length of females 353-447 $\mu \mathrm{m}$, of males 340-353 $\mu \mathrm{m}$. AD and PD with one and two pairs of small gland pores, respectively. Female GA with about 26-34 pgs, males with about $60 \mathrm{pgs}$, closely arranged around GO, and six outlying setae. Gnathosoma short, its length about or slightly less than half that of idiosoma, length of rostrum about $1 / 3$ that of gnathosoma. Legs short, leg I ca. 0.6-0.7 times the length of idiosoma. Most common combination of ventral setae on tibia I to IV (bipectinate setae included, the latter also in square brackets) 6[6], 5 [3], 3[1-2], 3[1-2]. Number of bipectinate ventral setae on tarsi I-IV 1, 1, 2, 1. Tarsi I to IV with 4, 4, 4, 3 dorsal setae. Each claw with accessory process.

Remarks. Lohmannella kervillei has an unusually short gnathosoma: its length is about or slightly less than half that of the idiosoma. Lohmannella nudipes has a similar short but slenderer gnathosoma and, in contrast to L. kervillei, the tarsi of $L$. nudipes lack bipectinate ventral setae.

Distribution. Eastern North Atlantic Ocean: records are from the Azores, Spain, France, Great Britain, Republic of Ireland, the Netherlands. Inhabitant of tidal crustose algae and coarse sand as well as subtidal Laminaria holdfasts and other seaweeds (Viets 1956; Bartsch 1977; Green and MacQuitty 1987; Somerfield 1991; Riesgo et al. 2010). André (1946) mentioned a record of an individual extracted from a $318 \mathrm{~m}$ depth (from ground with rocks), near the Azores. This depth is unusual, compared to other collecting data.

\section{Lohmannella lamellipes Newell, 1984}

Reference. Lohmannella lamellipes Newell 1984: 252, 258, 262, 263, Figs. 752-758 (female).

Depository. USNMNH.

Type locality. South Pacific Ocean, Chile, ca. $16 \mathrm{~km}$ south of Punta Arenas, $53^{\circ} 10^{\prime} \mathrm{S}, 70^{\circ} 56^{\prime} \mathrm{W}$.

Characters (according to Newell 1984). Length of female idiosoma $466 \mu \mathrm{m}$. Dorsal plates reticulated. Pairs of ds-5/glp-4 on either side adjacent and well removed from lateral margins of PD. Length ratio gnathosoma:idiosoma expected to be somewhat less than 0.9:1 (calculated from Newell 1984: Fig. 752). P-2 with four to five ventral spines. All legs with ventral lamellae. Tibia I with six bipectinate ventral setae.

Remarks. As indicated by the name 'lamellipes', the legs of this species are characterized by wide lamellae; such lamellae are otherwise not known in the genus Lohmannella. The arrangement of ds-5 and glp-4, almost immediately adjacent, resembles that of L. fukushimai. The last-mentioned species has slender legs, no spines on P-2, and the outline of the AD and PD differs from that of L. lamellipes.

According to Newell (1984: 263), the glp-5 are in the posterolateral corners of the PD (in contrast to the situation shown in Newell 1984: Fig. 753).

Distribution. South Pacific Ocean: Chile, Punta Arenas. Amongst sand in holdfasts of algae washed onto the beach (Newell 1984). 
23. Lohmannella masatierrae Newell, 1984

Reference. Lohmannella masatierrae Newell 1984: 252, 253, 257, 258, Figs. 729, 730 (male).

Depository. USNMNH.

Type locality. South Pacific Ocean: Chile, Juan Fernandez, Robinson Crusoe Island, Puerto Ingles, about $33^{\circ} 38^{\prime} \mathrm{S}, 78^{\circ} 50^{\prime} \mathrm{W}$.

Characters (according to Newell 1984). Length of male $344 \mu \mathrm{m}$. AD rectangular, its length and width almost the same. OC somewhat longer than wide, each one with two corneae; glp-3 near posteromedial margin of OC. Pairs of glp- 4 and ds- 5 in margin of PD, at almost the same level. Pair of glp-5 in margin of posterior part of PD. All gland pores similar in size. Pair of ds-3 and dorsal setae on PE distinctly longer than ds-2, ds-4 and ds-6. Male GA with 66 pgs close around the GO and six outlying setae close to lateral margins. P-2 without ventral spines. Tibia I with six bipectinate ventral setae.

Remarks. A similar arrangement and size of glp-2, glp-3 and glp-4, namely close to the margins of the OC and PD, is present in L. bispina, L. grandipora and L. multispina. Differences are, the ds-3 in L. masatierrae are situated in the striated integument (not on the PD) and are much longer than the ds- 4 and ds-5; moreover, the P-2 bears no ventral spine(s).

Distribution. South Pacific Ocean: Chile, Juan Fernandez, Robinson Crusoe Island. Tidal algae (Newell 1984).

\section{Lohmannella multisetosa Bartsch, 1986}

References. Lohmannella multisetosa Bartsch 1986: 233-235, Figs. 16-26 (female, deutonymph, protonymph); Bartsch 1991: 105 (female, deutonymph, protonymph).

Depository. ZMH.

Type locality. The Mediterranean Sea: France, Golfe du Lion, off Port-Miou, ca. $43^{\circ} 12^{\prime} \mathrm{N}, 5^{\circ} 31^{\prime} \mathrm{W}$.

Characters (according to Bartsch 1986 and 1991). Length of females 340-447 $\mu \mathrm{m}$. Surface of dorsal plates almost smooth. OC with one distinct cornea, rarely with a faint second one. Gland pores inconspicuous. Female GA with 51-74 pgs. Three pairs of genital acetabula enlarged, situated adjacent in line, anterior acetabulum reaching to anterior pair of sgs. Ventral margin of P-2 convex. Tibia I with three pairs of bipectinate ventral setae; tibia II ventromedially with three bipectinate setae, ventrolaterally with one seta; tibia III ventromedially with two to three and tibia IV with two bipectinate setae. Tarsi I to IV with 3, 3, 4, 3 dorsal setae and 1,1,2, 1 bipectinate ventral setae.
Remarks. Lohmannella multisetosa is at present the only species in which females have more than 50 pgs and remarkably enlarged genital acetabula. Males are, as of yet, not known.

Distribution. Eastern North Atlantic: France, English Channel, Roscoff; Sweden, Skagerrak. The Mediterranean Sea: France, Golfe du Lion. Subtidal sediments, 11-45 m depth (Bartsch 1986, 1991).

\section{Lohmannella multispina Newell, 1984}

Reference. Lohmannella multispina Newell 1984: 252, 258, 261, 262, Figs. 747-751 (female).

Depository. USNMNH.

Type locality. South Pacific Ocean: Chile, Arica, $18^{\circ} 28^{\prime} \mathrm{S}, 70^{\circ} 18^{\prime} \mathrm{W}$.

Characters (according to Newell 1984). Length of female $255 \mu \mathrm{m}$. Pairs of ds-2, ds-3 and ds- 4 inserted on $\mathrm{AD}, \mathrm{PD}$, and in posteriorly acuminate corner of OC, respectively. Pores glp-3 in medial corner of OC, glp-4 in margin of PD, ds-5 levelling with glp-4 but removed from lateral margins of PD. OC without cornea. Gnathosoma slender; length 0.7 times of that of idiosoma. P-2 with three to four ventral spines. Tibia I with six (rarely five) bipectinate ventral setae.

Remarks. The species is rather small-sized; it has three to four ventral spines on P-2; and the ds-4 are in the posterior corner of the $\mathrm{OC}$, not in the striated integument between PD and PE as in the other exclusively marine species.

Distribution. South Pacific Ocean: Chile, Arica. Extracted from mid-tidal coarse shell fragments (Newell 1984).

\section{Lohmannella njoerdri Bartsch, 2020}

Reference. Lohmannella njoerdri Bartsch 2020: 278-281, Figs. 1-16 (female, male).

Depository. ZMH.

Type locality. Eastern North Atlantic: Norway, Sula Ridge, $64^{\circ} 05^{\prime} \mathrm{N}, 8^{\circ} 02^{\prime} \mathrm{E}, 285 \mathrm{~m}$ depth.

Characters (according to Bartsch 2020). Length of female $314 \mu \mathrm{m}$, of male $310 \mu \mathrm{m}$. Dorsal plates uniformly covered with delicate, minute papillae. AD hexagonal, major part of PD rectangular. OC with two corneae. Gland pores vestigial. Pairs of ds-2, ds-3 and ds- 4 in striated integument. Length of gnathosoma 0.6 times that of idiosoma. Length of P-2 5.8 times the diameter. All legs shorter than idiosoma. Tibia I with six bipectinate ventral setae. Tarsus IV with three dorsal setae. Tarsi I to IV with 2, 1, 2, 1 bipectinate ventral setae, respectively. Claws very slender; length of claw I 8.3 times the width. 
Remarks. The most striking character is the shape of the claws: they are, in contrast to other known species, long and very slender.

Distribution. Eastern North Atlantic: Sula Ridge, Norway, $64^{\circ} 05^{\prime} \mathrm{N}, 8^{\circ} 02^{\prime} \mathrm{E}, 285 \mathrm{~m}$ depth. The mite was extracted from small pieces of Lophelia sp. (Scleractinia) (Bartsch 2020).

\section{Lohmannella norvegica Viets, 1927}

(in Viets 1927b)

References. Lohmannella norvegica Viets 1927b: 149, 150, Figs. 86-92a, b (female); Bartsch 1977: 152, 153 (female).

Depository. ZMH.

Type locality. Norway, Bergen, Sten Sund, ca. $60^{\circ} \mathrm{N}, 5^{\circ} \mathrm{E}$, from Laminaria growing near the low water edge.

Characters (according to Viets 1927b). Length of females about $425-434 \mu \mathrm{m}$. Gland pores not described. AD slightly wider than PD; both plates with evenly arched lateral margins. Gnathosoma short, about half the length of idiosoma. Stout basal seta on P-2 at 0.3 . Tibia I with six and tarsi I to IV with 1, 1, 2, 1 bipectinate ventral setae.

Remarks. Most Lohmannella species have a gnathosoma within the length range equalling 0.7 to about 1.0 times the length of idiosoma; in L. norvegica, the length of the gnathosoma is only half that of the idiosoma. A similar short gnathosoma is present in L. heptapegoni, L. kervillei, L. nudipes, $L$. reducta and $L$. steueri. The tarsi of $L$. nudipes lack ventral setae, the tibiae I of L. heptapegoni and L. steueri bear five bipectinate ventral setae, instead of six. Lohmannella kervillei shares several characters with $L$. norvegica but is more compact, its rostrum and palps are shorter than $L$. norvegica's. The P-4 of $L$. norvegica is longer than the diameter of P-2 (cf. Viets 1927b: Fig. 89), whereas in L. kervillei, the length of $\mathrm{P}-4$ hardly surpasses the diameter of P-2 in its posterior part (cf. Bartsch 1977: Figs. 22 and 23). The description of $L$. norvegica is far from detailed and, unfortunately, the holotype allows no detailed examination. Studies of new material from Bergen (Norway) are recommended.

Distribution. Eastern North Atlantic: Norway, Bergen. Extracted from Laminaria (Phaeophyta) and red algae, from the low water edge to $25 \mathrm{~m}$ depth (Viets 1927b). A record from Great Britain, Cornwall (Pugh 1988), turned out to be one of L. kervillei (Somerfield 1991). Since the description of $L$. norvegica is far from detailed, records from outside Norway are in need of verification and are hence not included in Fig. 4.
28. Lohmannella nudipes Bartsch, 1977

Reference. Lohmannella nudipes Bartsch 1977: 147, 148, Figs. 31-40 (female).

\section{Depository. MNHNP.}

Type locality. Eastern North Atlantic: France, English Channel, Finistère, estuary of River Penzé, $48^{\circ} 42^{\prime} \mathrm{N}, 3^{\circ} 58^{\prime} \mathrm{W}$.

Characters (according to Bartsch 1977). Length of female $390 \mu \mathrm{m}$. Gland pores inconspicuous. Pair of ds-2 on AD. Each OC with two corneae. Gnathosoma about half the length of idiosoma. Tibiae I to IV with $5,4-5,3,3$ ventral setae, of these 5, 3, 2, 3 bipectinate. None of tarsi with strong ventral setae.

Remarks. The tarsi of L. nudipes have parambulacral setae and eupathidia but no solid ventral setae; this character is shared with the freshwater species $L$. andrei. However, each OC of L. nudipes bears two corneae (vs. none in $L$. andrei) and the PD of $L$. nudipes bears a single pair of setae (vs. two pairs in L. andrei).

Distribution. Eastern North Atlantic Ocean: France, coast of the English Channel, bay in the outer part of the estuary of Penzé River, north of Pte St Jean (Bartsch 1977). Extracted from tidal sediment.

\section{Lohmannella pinggi Otto, 1994}

References. Lohmannella pinggi Otto 1994: 32-35, Figs. 1-8 (female, male, deutonymph); Bartsch 2005b: 296-298, Figs. 3A-G (female); Bartsch 2007a: 380 (female).

Depository. ANIC.

Type locality. South Pacific Ocean: Australia, Victoria, Ricketts Point, $38^{\circ} 00^{\prime} \mathrm{S}, 145^{\circ} 02^{\prime} \mathrm{E}$.

Characters (according to Otto 1994 and Bartsch $2005 \mathrm{~b}, 2007 \mathrm{a}$ ). Length of females $278-437 \mu \mathrm{m}$, of males 382-424 $\mu \mathrm{m}$. AD hexagonal; ds-1 situated anterior to glp-1. OC elongate; its length more than twice the width. Pair of glp-2 on small sclerites in ventral position, glp-3 near medial margin of OC. Female GA with 16-18 pgs, that of male with about 50 setae closely arranged around GO and four pairs of outlying pgs. Legs stout. Genu and tibia I with four and seven bipectinate ventral setae, respectively. Tarsi I to IV with 4, 4, 4, 3 dorsal and 2, 2, 4, 2-3 solid ventral setae, respectively; some of the ventral setae delicately bipectinate, others smooth. Claws apically with tines.

Remarks. Lohmannella pinggi has unusually long OC: their length is 2.4 or more the width. In other Lohmannella species, the L:W ratio is between 1.2 and 2.3:1. 
There are differences between the type specimens from Victoria and individuals from Western Australia. The idiosoma of the mites from Western Australia is smaller (length of females 278-303 $\mu \mathrm{m}$ vs. $378-437 \mu \mathrm{m}$ ); the OC bears one distinct and one faint cornea (vs. one large cornea); the ds- 1 are slender and distinctly longer than the short, slightly spiniform ds-1 in the material from Victoria (Otto 1994: Fig. 1). Examination of additional specimens is needed to decide if the characters of L. pinggi are highly variable or if the individuals from the south-eastern and the south-western parts of Australia are representatives of two separate species.

Distribution. Indian Ocean: Western Australia, off Perth, Rottnest Island and Esperance, Nine Mile Beach; Victoria, Ricketts Point; South Pacific Ocean: New South Wales, from Malua Bay to Mystery Bay. All individuals were extracted from tidal coralline algae (Otto 1994; Bartsch 2005b, 2007a).

30. Lohmannella rectangulops Newell, 1984

References. Lohmannella rectangulops Newell 1984: 252, 253, 255, Figs. 721-725 (female, male); Pepato 2010: 183, 184, Figs. 28A-C, 29A-B, 30.

Depository. USNMNH.

Type locality. South Pacific, Chile, Valparaiso, Viña del Mar, $33^{\circ} 02^{\prime} \mathrm{S}, 71^{\circ} 38^{\prime} \mathrm{W}$.

Characters (according to Newell 1984, mainly of holotype female). Length of female $395 \mu \mathrm{m}$. AD longer than PD. Posterior margin of AD semi-circular, anterior margin of PD slightly concave. OC elongate, length more than twice the width. PD almost rectangular. All gland pores distinct; glp-3 closer to medial than to lateral margin of $\mathrm{OC}$; pairs of glp-4 and glp-5 in margin of PD. Pairs of ds-3 somewhat longer than ds-2, ds- 4 and ds-5. Anterior margin of female and male GA broadly arched, lateral margins in almost parallel arrangement. Perigenital setae close to anterior margin of GA. No ventral spine on P-2. Tibia I with 5 and tarsi II to IV with 1, 2, 1 bipectinate ventral setae.

In addition to these external morphological characters, Pepato (2010) published details of the spermatogenesis.

Remarks. The dorsal aspect of the speciesnamely, the large areas of striated integument, bowl-shaped $\mathrm{AD}$, distinct gland pores, and short, almost rectangular PD - resembles that of L. bihamata, L. hureaui and L. setosa Newell, 1984. However, tibia I of $L$. rectangulops has only five spiniform ventral setae whereas the three other species have six setae. However, the number of setae on the tibiae may vary, e.g., in L. multispina, the most commonly found number is six, but one individual had solely five bipectinate setae. Other distinguishing characters are: tibia II of L. bihamata are longer and slenderer than in $L$. rectangulops (cf. Newell 1984: Figs. 721 and 724); L. setosa has large dorsal setae and gland pores, which are absent in L. bihamata, L. hureaui and L. rectangulops.

Lohmannella species that have five bipectinate ventral setae on tibia I are: L. abyssalis, L. nudipes and L. steueri. Distinguishing characters are: L. abyssalis has a ventral spiniform process on $\mathrm{P}-2$ and the pair of $\mathrm{P}-1$ is separated by the width of $\mathrm{P}-1$; the tarsi of $L$. nudipes lack bipectinate ventral setae; in L. steueri, the gland pores are vestigial.

Distribution. South Pacific Ocean: Southern Chile, Valparaiso (Newell 1984; Pepato 2010). Extracted from tidal corallines and mussels.

\section{Lohmannella reducta Bartsch, 1986}

Reference. Lohmannella reducta Bartsch 1986: 232-233, Figs. 318-335, Figs. 4-15 (female, male, deutonymph).

\section{Depository. ZMH.}

Type locality. The Mediterranean Sea: France, Golfe du Lion, off Port-Miou. $43^{\circ} 12^{\prime} \mathrm{N}, 5^{\circ} 31^{\prime} \mathrm{W}$.

Characters (according to Bartsch 1986). Length of females $318-335 \mu \mathrm{m}$, of a male $278 \mu \mathrm{m}$. Surface of dorsal plates delicately papillate. $\mathrm{AD}$ hexagonal. PD with faintly raised V-shaped area. OC with two corneae. Female GA with about 30 pgs, male GA with $64 \mathrm{pgs}$, six of these outlying. Gnathosoma slightly more than half the length of idiosoma. Genu and tibia I with three and four bipectinate ventral setae, respectively, tibiae II, III and IV with 2, 1 and 2 such setae. Tarsi I to IV with 2, 1, 2, 1 bipectinate ventral and 4, 4, 4, 3 smooth dorsal setae, respectively. Claws with accessory process.

Remarks. The most common number of bipectinate ventral setae on tibia I in Lohmannella species is five to seven; L. reducta is one of the few species with no more than four such setae. A similarly low number of setae is found in the brackish/ fresh water inhabiting L. heptapegoni and L. stammeri. In contrast to the two aforementioned species, the OC of L. reducta are wide, their posterior margins semi-circular and they bear two corneae but no setae. Additionally, L. reducta's ds-4 are in the striated integument posterior to the OC (vs. OC slender, posterior part acuminate, each $\mathrm{OC}$ with one seta; pair of ds-4 on the PD).

Distribution. The Mediterranean Sea: France, Golfe du Lion. Extracted from 20-40 m depth (Bartsch 1986). 
32. Lohmannella reticulata Viets, 1950

Reference. Lohmannella reticulata Viets 1950: 31-33, Fig. 10A-D (male); Bartsch: present paper, Fig. 4E (female).

Depository. NRS (holotype) and ZMH (paratype females and males).

Type locality. South Atlantic Ocean: Falkland Islands, Berkeley Sound, 51 $33^{\prime} \mathrm{S}, 58^{\circ} 00^{\prime} \mathrm{W}$.

Characters (according to Viets 1950 and paratypes housed in ZMH). Length of females 390$428 \mu \mathrm{m}$, of males-344-390 $\mu \mathrm{m}$. AD and PD hexagonal. Dorsal plates reticulate and with porose areolae. AD with oblong porose areola between ds- 1 and two small, circular ones adjacent to glp-1; OC with porose areola near cornea; PD with narrow $\mathrm{V}$-shaped areola in its posterior half. Setae ds-1 anterior to the level of glp-1. Pair of glp-3 closer to medial corner than to lateral edge of OC. Pair of ds-5 distinctly posterior to glp-4. Anterior part of female (Fig. 3E) and male GA truncate. Female with 19(?) scatteredly arranged pgs; males with 59 pgs in a dense ring around $\mathrm{GO}$ and additional three pairs of outlying setae removed from anterior and lateral margins. Length ratio of gnathosoma:idiosoma 0.6:1. Rostrum about as long as gnathosomal base. Basal half of P-2 slightly widened. Tibia I with six bipectinate ventral setae. Tarsi I to IV with $1,1(-2)$, 2, (1-)2 ventral setae.

Remarks. The dorsal plates of Lohmannella antarctica and $L$. reticulata demonstrate the same ornamentation, the surface is reticulated and the $\mathrm{AD}, \mathrm{OC}$ and $\mathrm{PD}$ have porose areolae. Lohmannella reticulata is somewhat smaller than $L$. antarctica (females 390-428 $\mu \mathrm{m}$ vs. $430-470 \mu \mathrm{m}$, males $344-390$ vs. $420-430 \mu \mathrm{m}$ ), the glp-3 are closer to the medial than to the lateral corner of the OC (vs. the opposite in L. antarctica), the pairs of glp-4 and ds-5 are widely separated, and the rostrum and legs are not as slender as in L. antarctica. Detailed examination of individuals from the type localities is needed to evaluate the taxonomic status of $L$. antarctica and $L$. reticulata.

Distribution. South Atlantic Ocean: Falkland Islands. Coarse subtidal sand with shell and algae; extracted from 12-16 m depth (Viets 1950, 1952).

\section{Lohmannella rustica Bartsch, 1977}

Reference. Lohmannella rustica Bartsch 1977: 149-152, Figs. 43-51 (female, male, deutonymph, protonymph, larva).

Depository. MNHNP.

Type locality. Eastern North Atlantic Ocean: France, Finistère, Roscoff, ca. $48^{\circ} 44^{\prime} \mathrm{N}, 3^{\circ} 59^{\prime} \mathrm{W}$.
Characters (according to Bartsch 1977). Length of females 297-335 $\mu \mathrm{m}$, of male $273 \mu \mathrm{m}$. Pair of ds-1 much longer than following setae. Pairs of glp1 to glp-3 inconspicuous; glp-4 and glp-5 minute, both pairs of pores on PD; glp-4 somewhat posterior to ds-5, glp-5 situated rather close together near posterior margin of PD. Female GA with about 22-29 pgs near GO and 10-12 peripheral ones. Male with 45 pgs close around GO and 10 outlying setae. Length ratio gnathosoma:idiosoma equalling $0.6-$ 0.7:1. Length of P-2 5.3 times that of its basal width. Number of ventral setae on tibiae I to IV (bipectinate setae included and additionally given in square brackets): 6[6], 5[3] 3[1], 3[3], respectively. Tarsi I to IV with 4, 4, 4, 4 dorsal setae and 1, 1(-2), 2, 1 bipectinate ventral setae. Claws smooth.

Remarks. Lohmannella rustica had been found together with Lohmannella kervillei, a species rather similar in the outline of idiosoma. Lohmannella rustica is smaller, its gnathosoma and legs (especially the tibiae) are longer and slenderer, and L. rustica is one of the few species with four (instead of three) dorsal setae on tarsus IV.

Distribution. Eastern North Atlantic Ocean: France, the English Channel, Roscoff. Tidal crustose red algae (Lithophyllum sp.) (Bartsch 1977).

34. Lohmannella septemsetosa Bartsch, 2005 (in Bartsch 2005b)

Reference. Lohmannella septemsetosa Bartsch 2005b: 293-296, Figs. 1A-K, 2A-F (male, deutonymph); Bartsch 2007a: 380, 381, Fig. 10A-B (female, larva).

Depository. WAM.

Type locality. Indian Ocean: Western Australia, near Esperance, Lucky Bay, Cape le Grand, $34^{\circ} 00^{\prime} \mathrm{S}, 122^{\circ} 14^{\prime} \mathrm{E}$.

Characters (according to Bartsch 2005b, 2007a). Length of female $447 \mu \mathrm{m}$, of male $410 \mu \mathrm{m}$. Dorsal plates with delicate reticulate to maze-like ornamentation. All five pairs of glp large; glp-2 in ventromarginal position on platelets, their width more than twice the diameter of glp; glp-3 in middle of OC; glp-4 close to lateral margin of PD, immediately posterior to ds-5; pair of glp-5 widely separated. Female GA with 17 pgs, male GA with 55 pgs close to GO and six outlying setae. P-2 without ventral spines. Basal setae of P-2 close to the segment's basis. Genu and tibia I with four and (six to) seven bipectinate ventral setae, respectively. Tarsi I to IV ventrally with 2, 2, 4, 3 solid, more or less bipectinate ventral setae. Tarsi I to IV with 4, 4, 4, 3 dorsal setae. Claws with accessory process. 
Remarks. The combination of characters of $L$. septemsetosa - namely, large gland pores and six to seven ventral spines on tibia I-is found in $L$. dictyota, L. gaussi, L. kerguelensis and L. pinggi. The dorsal plates of L. dictyota and L. gaussi have distinctly delimited porose areolae, whereas the plates of L. septemsetosa demonstrate a uniform, very delicate ornamentation. The anterior part of the PD of L. kerguelensis is bluntly oviform, while that of L. septemsetosa is truncate. Lohmannella pinggi has unusually long OC (length is 2.4 and more times the width); those of $L$. septemsetosa are shorter (length:width 1.9:1).

Distribution. Indian Ocean: Western Australia, near Esperance; extracted from algal turf with sediment, from 30-50 cm depth (Bartsch 2005b, 2007a).

\section{Lohmannella setosa Newell, 1984}

Reference. Lohmannella setosa Newell 1984: 252, 253, 255, 256, Figs. 726-728 (female, male, deutonymph).

Depository. USNMNH.

Type locality. South Pacific Ocean: Chile, San Felix Island, $26^{\circ} 18^{\prime} \mathrm{S}, 80^{\circ} 06^{\prime} \mathrm{W}$.

Characters (according to Newell 1984). Length of female $264 \mu \mathrm{m}$. Surface of dorsal plates minutely tuberculate. AD longer and wider than PD. Posterior margin of AD semi-circular. OC oblong. PD rectangular. Pairs of glp-1, glp-3, glp-4, and glp-5 large. Setae ds-1, ds-3 and dorsal setae on PE distinctly larger than ds- 2 , ds -4 , ds -5 , and ds- 6 ; ds- 1 with delicate setulae. PD with glp-4 and ds- 5 situated close together in lateral margin of the plate and only slightly removed from anterior margin.

Remarks. Lohmannella setosa can be distinguished from the other Lohmannella species on the basis of the aforementioned character combination. Some of the characters are shared with L. rectangulops, but in that species the dorsal setae are not as enlarged as in L. setosa; moreover, the glp-3 are smaller and the ds- 5 posterior to glp- 4 . Newell (1984) expected L. setosa to be similar to L. masatierrae, a species known only by its male. The shape of the dorsal plates of L. masatierrae is markedly different.

Distribution. South-eastern Pacific: Chile, San Felix Islands. Extracted from tidal coralline algae (Newell 1984).

36. Lohmannella stammeri Viets, 1939 (in Viets 1939a)

Reference. Lohmannella stammeri Viets 1939a: 626-628, Figs. 1-8 (female, male, deutonymph, protonymph); Bartsch 1977: 152-153 (female, male); Bartsch 1986: Fig. 3 (female); Bartsch 2006a: 149-150, Fig. 5a-f; Pešić 2004: 38, 39, Figs. 1-3 (male).

Depository. ZMH.

Type locality. The Mediterranean Sea: Italy, Province Lesse, Abisso Grotte, ca. $40^{\circ} 00^{\prime} \mathrm{N}$, $18^{\circ} 25^{\prime} \mathrm{E}$, near Castro marine (Terrá d'Otranto), west of Santa Cesarea.

Characters (according to Viets 1939a and Bartsch 1977). Length of females 297-324 $\mu \mathrm{m}$, of males 297-320 $\mu \mathrm{m}$. Surface of dorsal plates smooth. Pair of glp-1 distinct, in margin of AD. Pair of OC rather slender, slightly obliquely arranged, posterior angle pointed, plate with a seta, a gland pore but no cornea. PD rectangular, with pair of gland pores in posterior third of plate, removed from lateral margin; a second pair of glp near posterior margin. Female GA ovate, with slightly arched lateral and semi-circular anterior margins. Lateral margins of male GA anteriad converging; anterior part distinctly less than half the width of middle part of GA. Females and males with internal gac shining through genital sclerites. P-2 with convex ventral margin. P-4 short. Gap between pair of P-1 equalling almost half the width of the segments. Telofemur I with two slightly pectinate ventral setae; genu, tibia and tarsus I with 3, 4, 1-2 bipectinate ventral setae. Tibiae II to IV with 4, 3, 3 and tarsi II to IV with 2, 1-2, 1 ventral setae, respectively. Claws very slender, almost smooth.

Remarks. Lohmannella stammeri is very similar to L. heptapegoni. In both species, the length of the idiosoma and the shape of the male GA are similar, tibia I of both species has four bipectinate ventral setae and tarsi I and II with two (rarely one) bipectinate ventral setae. According to the description, the gnathosoma of L. heptapegoni is shorter than that of L. stammeri: namely, in L. heptapego$n i$, its length is slightly less than half (vs. distinctly more than half in L. stammeri) the idiosomal length. In L. stammeri, the gap between the pair of P-1 almost equals half the width of these segments; in L. heptapegoni, that size is not known. A careful re-examination of individuals collected near the type localities is recommended.

The types of Lohmannella stammeri had been extracted from a brackish water pond in a nearshore part of a cave (Viets 1939a).

Distribution. The Mediterranean Sea: southeastern Italy, Castro Marine Salentina, west of Santa Cesarea, Otranto, nearshore cave with brack- 
ish water pond (distance to the sea about $200 \mathrm{~m}$ ) (Viets 1939a). More records of the species are from Monte Negro (Crna Gora), Durmitor Mountains, Mlinski Potok, stream near Crno Lake, 1,450 m a.s.1. (Pešić 2004). The mite obviously inhabits both fresh and slightly brackish water.

37. Lohmannella steueri Viets, 1940

References. Lohmannella steueri Viets 1940: 92, 93, Figs. 138-142 (female, male); Bartsch 1977: 152-153, Figs. 41, 42 (female, male); Bartsch 1986: Fig. 3 (female).

Depository. ZMH.

Type locality. The Mediterranean Sea: Adriatic Sea, Croatia, Rovinj, $45^{\circ} 05^{\prime} \mathrm{N} 13^{\circ} 38^{\prime} \mathrm{E}$, Val de Bora.

Characters (according to Viets 1940; this and further specimens housed in $\mathrm{ZMH}$ ). Length of females 328-345 $\mu \mathrm{m}$, of males 335-345 $\mu \mathrm{m}$. AD and PD almost equal in width. AD and OC with eye pigment, OC with two corneae. Lateral margins of PD slightly and evenly arched. P-2 slightly curved, its basal seta long and strong, situated in basal part, at about 0.2 . P-4 short, $1 / 5$ the length of P-2. Genu and tibia $I$ with $(2-) 3$ and 5 bipectinate ventral setae, respectively. Tarsi I to IV with 4, 4, 4, 3 dorsal and 2, 1, 2, 1 stout ventral setae.

Remarks. The Mediterranean species Lohmannella falcata, L. multisetosa, L. stammeri and $L$. steueri are rather similar in size; they can be distinguished on the basis of their palps. The P-2 of L. falcata and L. steueri are straight. In L. falcata, the P-4 are long and the P-2 2.8 times longer than P-4; in L. steueri, the P-4 are short, the P-2 4.3 times longer than P-4. In L. multisetosa and L. steueri, the ventral margin of $\mathrm{P}-2$ is convex in its middle part. The females of $L$. multisetosa have a much larger number of perigenital setae than those of L. steueri (50-74 vs. 27). Lohmannella reducta - another species known from the Mediterranean Sea-is smaller and has four bipectinate ventral setae on tibia I (vs. five in L. steueri).

Distribution. The Mediterranean Sea: Adriatic Sea, Croatia. Shallow water algae. Extracted from various substrata dredged in 25-28 m depth (Viets 1940).

38. Lohmannella subfalcata Bartsch, 2003

(in Bartsch 2003a)

Reference. Lohmannella subfalcata Bartsch 2003a: 102-106, Figs. 1-11 (female, deutonymph, larva).

Depository. ZMH.

Type locality. Eastern North Atlantic: Great Meteor Seamount, $29^{\circ} 54^{\prime} \mathrm{N}, 28^{\circ} 22^{\prime} \mathrm{W}$.
Characters (according to Bartsch 2003a). Length of females about 295-314 $\mu \mathrm{m}$. Dorsal plates almost smooth; gland pores inconspicuous. AD hexagonal, wider than PD. OC with one distinct and one faint cornea. Female GA with 43-45 pgs scatteredly arranged around GO. Gnathosoma slender, its length 0.8 times that of idiosoma. Legs slender, almost as long as idiosoma. Genu and tibia I with three and six bipectinate ventral setae, tibiae II to IV with 5, 4, 3 ventral setae, of these 3, 0,2 bipectinate; the other setae smooth. Tarsi I to IV with 4, 4, 4, 3 dorsal setae and 2, 1, 2, 1 bipectinate ventral setae. Claws almost smooth.

Remarks. The species is similar to L. falcata, but the PD of L. subfalcata is shorter; the gnathosoma and legs are longer than in L. falcata; and tarsus IV has no more than three dorsal setae (vs. four in L. falcata). A specimen by Bartsch (1973a) mentioned as L. falcata belongs to L. subfalcata.

Distribution. Eastern North Atlantic: Great Meteor Seamount, at 318-332 m depth (Bartsch 1973a, 2003a).

\section{Lohmannella sulensis Bartsch, 2020}

Reference. Lohmannella sulensis Bartsch 2020: 281-283, Figs. 17-32 (female).

Depository. ZMH.

Type locality. Eastern North Atlantic: Norway, Sula Ridge, $64^{\circ} 05^{\prime} \mathrm{N}, 8^{\circ} 02^{\prime} \mathrm{E}$.

Characters (according to Bartsch 2020). Length of female $386 \mu \mathrm{m}$. AD 1.5 times wider than long (L:W 0.7:1), PD only slightly wider than long; anterior part wider than posterior half. Length of gnathosoma 0.9 times of that of idiosoma. Rostrum longer than gnathosomal base. Palps slender. Length of P-2 seven times the diameter. P-4 slender. Length of P-2 equalling 2.5 times that of P-4. Leg I almost as long as idiosoma, leg IV somewhat longer. Tibia I with six bipectinate ventral setae. Tarsus IV with four dorsal setae.

Remarks. The most obvious characters of Lohmannella sulensis are: AD distinctly wider than long and wider than PD; gnathosoma almost as long as idiosoma; palps long and slender, length ratio P-2:P-4 about 2.5:1; legs long, slender, nearly as long as idiosoma; tibia I with six bipectinate ventral bristles, tarsus of leg IV with four dorsal setae. Amongst the world-wide spread Lohmannella species, three share some, but not all, of these characters. Lohmannella cygna is characterized by its very wide $\mathrm{AD}$ and a long and slender gnathosoma; but its P-4 is short, if compared with P-2, tibia I has four pairs of bipectinate setae, and 
tarsus IV has three dorsal setae. Gnathosoma, palps and P-4 of L. fukushimai are very long; but tibia I bears seven bipectinate ventral setae, and tarsus IV three dorsal setae (Imamura 1968; Bartsch 1993). Lohmannella lamellipes is another species with a wide $\mathrm{AD}$ and long P-4; this species is unique in the wide lamellae on the legs.

Distribution. Eastern North Atlantic: Norwegian Sea, Norway, Sula Ridge, 285 m. Extracted from small pieces of the scleractinian Lophelia sp. (Bartsch 2020).

\section{Lohmannella sp. A}

Reference. Lohmannella sp. A Bartsch 1982: 449-451, Figs. 53-60 (damaged female, gnathosoma lacking).

Depository. Author's halacarid collection.

Collecting site. Indian Ocean: Mozambique Channel, $13^{\circ} 05^{\prime} \mathrm{S}, 45^{\circ} 08^{\prime} \mathrm{E}, 400-520 \mathrm{~m}$.

Characters. Length of female $545 \mu \mathrm{m}$. Dorsal plates with delicately reticulated epicuticula, else without distinct ornamentation. AD longer than PD. $\mathrm{PD}$ with horn-like projection; in mounted specimen (pressed between cover slips), projection extending beyond anal cone. Pairs of glp-1, glp-2, glp-3 and glp-5 small; glp-4 replaced by small setae. Epimera I and II with prolonged articular membranes flanking the trochanters. Legs long and slender; leg I 1.2 times longer than idiosoma. Tibia I with 8 and tarsus I with 4 bipectinate ventral setae. Tarsi II to IV with 3-4, $6,4-5$ solid ventral setae, respectively.

Remarks. The species shares several characters with L. cygna and L. fukushimai: ornamentation of dorsal plates very delicate, glp-4 replaced by minute setae, legs long and slender, and seven to eight bipectinate ventral setae on tibiae I. The most obvious character of this species is the horn-like projection on the PD. No similar projection has been mentioned before.

\section{Lohmannella sp. B}

Reference. Lohmannella falcata, Bartsch 1978a: 60, Fig. 42 (female, deutonymph).

Depository. MNHNP and author's halacarid collection.

Collecting site. Eastern North Atlantic Ocean: Norwegian Basin, $64-69^{\circ} \mathrm{N}, 0-10^{\circ} \mathrm{E}$.

Characters. Idiosomal length of two females 412 and $417 \mu \mathrm{m}$, gnathosomal length 232 and $243 \mu \mathrm{m}$. Legs slender. Genua and tibiae I ventrally with two to three and five to six bipectinate setae, respectively. Tarsus IV with three dorsal setae.

Remarks. Bartsch (1978a) called these specimens tentatively Lohmannella falcata. In the meantime, the knowledge of character variability of Lohmannella species has increased. Characters such as the shape and chaetotaxy of the legs (Bartsch 1978a) do not support the conspecificity of these deep-sea individuals with L. falcata.

Distribution. Eastern North Atlantic Ocean: Norwegian Basin, $64-69^{\circ} \mathrm{N}, 0-10^{\circ} \mathrm{E}$, extracted from hydrozoans and sponges dredged in 2,5382,957 m depth (Bartsch 1978a).

\section{Lohmannella sp. C}

Reference. Lohmannella sp. 1, Bartsch 2013: 245. Depository. Author's halacarid collection.

Collecting site. South-western Pacific Ocean: North Fiji Basin, $17^{\circ} \mathrm{S}, 174^{\circ} \mathrm{W}$.

Characters and Remarks. Female $560 \mu \mathrm{m}$ in length. Similar to L. cygna in: shape of dorsal and ventral plates, arrangement of setae and gland pores, prolonged anal cone with pair of nipper forceps, long and slender gnathosoma and legs. The differences between the two species are in the number of bipectinate ventral setae on genu and tibia I: the specimen from the North Fiji Basin has 4-5 and 7 setae, respectively, but L. cygna has 5 and 8 setae. The individual from the North Fiji Basin may be conspecific with L. cygna, since in the genus Lohmannella, the number of bipectinate ventral setae is known to vary.

Distribution. South-western Pacific Ocean: North Fiji Basin, $17^{\circ} \mathrm{S}, 174^{\circ} \mathrm{W}, 2,000 \mathrm{~m}$, collected in the course of the French-Japanese project STARMER II Cruise.

\section{Lohmannella sp. D}

Reference. Lohmannella sp. 2, Bartsch 2013: 245.

Depository. Author's halacarid collection.

Collecting site. Eastern Pacific Ocean, SouthEast Pacific Rise, $9^{\circ} 51^{\prime} \mathrm{N}, 104^{\circ} 18^{\prime} \mathrm{W}, 2,500 \mathrm{~m}$ depth.

Characters. Length of female $510 \mu \mathrm{m}$, width $490 \mu \mathrm{m}$. Integument almost smooth except for small porose areas on PD and marginally on PE. PD with an unpaired porose area near posterior margin, size of area about $22 \times 17 \mu \mathrm{m}$, and a pair of ovate areas, $30 \times 12 \mu \mathrm{m}$, immediately medial to ds- 5 and glp-4. On PE porose area anterior to insertion of leg III. AD hexagonal with rounded corners, lateral margin arched, posterior margin slightly excavate; length $152 \mu \mathrm{m}$, width $75 \mu \mathrm{m}$. OC trapeziform, length $130 \mu \mathrm{m}$, width $75 \mu \mathrm{m}$; corneae lacking. PD ovate, length $270 \mu \mathrm{m}$, width $213 \mu \mathrm{m}$; anterior margin arched, lateral margins slowly converging, plate widest at 0.3 . Pair of ds- 1 on AD at 0.3 ; setae slender, longer than following ones. Pairs of ds-2, ds-3 and ds- 4 within striated integu- 
ment, ds-5 on PD at 0.7 and distinctly removed from lateral margin of the plate. Pair of ds- 6 on anal cone; almost adjacent. Gland pores distinct but not on cones. Pair of glp- 1 on the same level as ds-1. Pair of glp-2 on ventromarginal sclerites, glp-3 in middle of OC, level with the porus canaliculus; glp 4 slightly posterior to ds-5; distance to lateral margin of PD same as interval between ds- 5 and margin of plate. Pairs of glp-5 in posterior margin of $\mathrm{PD}$; distance between pores equalling $1 / 3$ the width of PD. Length of AE $200 \mu \mathrm{m}$, width $350 \mu \mathrm{m}$; its posterior margin truncate. AE with four pairs of setae, each PE with two dorsal and three ventral setae. Length of GA $240 \mu \mathrm{m}$, width $190 \mu \mathrm{m}$. GA with 18 pgs. Distance between GO and rectangular anterior part of GA 1.3 times length of GO. Length of gnathosoma $350 \mu \mathrm{m}$, width $134 \mu \mathrm{m}, \mathrm{L}: \mathrm{W}$ 2.6:1. Rostrum slender. P-2 8.4 times longer than its basal width. Length of leg I about 0.7 times idiosomal length. Genua I to IV with 4, 4, 2-3, 3 ventral setae, of these $4,1,0,0$ distinctly bipectinate. Tibiae I to IV with 7, 5, 5-6, 5 ventral setae, on tibia I all 7 setae bipectinate. Tarsi I to III with 2, 2, 4 ventral setae (eupathidia omitted) and 4, 4, 4, dorsal setae (solenidia included). Tarsus IV lacking. Each claw with tiny accessory process.

Remarks. In the shape of dorsal and ventral plates, position of setae and gland pores, length of gnathosoma and chaetotaxy of legs, the species slightly resembles L. kerguelensis, but that species is not known to have porose areolae on the dorsal plates.

Porose areolae on the PE are present in a few southern but generally not in northern hemisphere species.

Distribution. South-East Pacific Rise, $9^{\circ} 51^{\prime} \mathrm{N}$, $104^{\circ} 18^{\prime} \mathrm{W}, 2500 \mathrm{~m}$ depth (coll. J. Zekely).

\section{Lohmannella sp. E}

Depository. Author's halacarid collection.

Collecting site. Eastern North Atlantic: Great Meteor Seamount, $30^{\circ} 05^{\prime} \mathrm{N}, 28^{\circ} 23^{\prime} \mathrm{W}, 511 \mathrm{~m}$.

Characters. Length of idiosoma of single female $248 \mu \mathrm{m}$, its width $210 \mu \mathrm{m}$. Length of AD $75 \mu \mathrm{m}$, width $108 \mu \mathrm{m}$, length:width 0.7:1. Lateral margin semi-circular, posterior margin truncate. Length of PD $110 \mu \mathrm{m}$. Anterior margin truncate. Gnathosoma slender; length $208 \mu \mathrm{m}$, width $80 \mu \mathrm{m}, 2.6$ times longer than the width of the basis. P-2 6.7 times longer than its basal width. Basal seta at 0.3 . Ventral flank with cuticular spine. Leg segments slender. Length ratio leg I:idiosoma equalling 0.8:1. Epimera I partly surrounding basal part of trochanter I. Length ratio telofemur to tibia 1.2:1. Genua I to IV with $4 / 3$,
4/3, 3/1, 3/1 dorsal/ventral setae. Tibia I with 6 pectinate ventral setae. Tarsi III and IV with $4 / 1$ and 3/1 dorsal/ventral setae. Claws slender.

Remarks. A striking character of this species is the spiniform ventral process on P-2. Similar spines are found in several southern hemisphere species but, as of yet, such spines have not been recorded in the northern hemisphere species. In its general shape, this species comes close to L. subfalcata, but the latter species has no spine on the P-2, the $\mathrm{PD}$ is shorter than the $\mathrm{AD}$, and the number and the arrangement of the setae on the legs is different.

\section{Tabular Key}

Table 1 presents a list of characters and their states in the 39 named Lohmannella species. Most of the data have been extracted from literature. Different interpretation of character states with respect to the ornamentation or the position of setae and pores cannot be excluded. When using the table, one should be aware that many of the descriptions are based on very few (and often just one) adult individuals. Little or nothing is known about the variability of characters or anomalies. The presented data may be interpreted by the reader in a way that was not intended by the describer, or the data may turn out to be rather uninformative, e.g., if only the number of setae, but neither the shape nor their position, is described. The data may be at (or even beyond) the general limit of what is typical for a given species. And, when summarizing data, errors may have slunk into the dataset. Therefore, once a preliminary identification of a species is done, the result should be carefully checked with the descriptions to verify or dismiss the obtained result.

\section{REMARKS AND DISCUSSION}

\section{Biology, morphology habitat and feeding}

With its 39 named species, the genus Lohmannella plays a minor role in the halacarid community, which includes about 1,130 species. Most of the halacarids live in the sea, only few in fresh water. Halacarids are generally oviparous and we can expect this to be true with respect to Lohmannella. Lohmannella go through one larval, protonymphal and deutonymphal stage until the adults - female or male-leave the skin of the deutonymphal instar. In most of the halacarid species studied, both females and males occur. This should certainly be true for Lohmannella species, except for, perhaps, L. multisetosa, since no males were found amongst more than 100 adults examined (Bartsch 1977). 
The few detailed observations of halacarid life cycles mainly concentrated on the species inhabiting tidal and shallow water zones in cold temperate areas (Straarup 1968; Kirchner 1969; Bartsch 1972). In a given population, the number of females and males seems to be rather similar, though, when summarizing monthly results, the total number of females is somewhat higher than that of males. This difference seems to be due to the somewhat longer life span of females. Thirty-nine Lohmannella species are listed in Table 1, and in 22 of them, both females and males are mentioned. In all, females of 35 species and males of 26 species are known. Since no detailed data sets based on samples taken regularly over at least one year are available, it is unknown whether females dominate in a given population (in terms of total numbers).

In halacarids, both sexes are generally similar in shape. With respect to the dorsal plates, the outline of the female and male PD of Lohmannella curvimandibulata and L. cvetkovi differs somewhat. The difference may be the result of compression between the coverslip and the slide. Sexual dimorphism is, of course, found in the genital region of Lohmannella, e.g., in the size and position of the $\mathrm{GO}$, the number and the arrangement of the perigenital setae, and in the absence (vs. presence) of the internal ovipositor or spermatopositor. However, sexual dimporphism is rarely manifested in the shape of the genitoanal plate. Such a difference is demonstrated by $L$. arenaria (Bartsch 1993b, Fig. 10E and B) and L. stammeri (Viets 1939a, Figs. 7 and 8).

The lifestyle and feeding behaviour of Lohmannella species are not known. The idiosoma of most species is flattened and wide, while the gnathosoma is slender: generally, more than half the length of (rarely even longer than) the idiosoma. The four pairs of legs are rather similar in shape, generally slender (with one exception); and none of the legs are markedly modified to catch and tightly hold prey. One may speculate that species with short legs and gnathosoma (legs 0.8 or less times the length of idiosoma) push their way through a dense substratum rich in narrow fissures. Examples of such adaptation include $L$. kervillei and $L$. rustica, which are often found between the crustose thalli of Lithophyllum (red algae). Species with somewhat longer legs and gnathosoma (e.g., L. falcata) move around between hapteres of brown algae (Laminaria), through the thickets of an epibios, as well as through coarse, unsorted sediment. Long-legged species (such as L. fukushimai) are expected to inhabit the surface of a given substratum. Long-legged species may even belong to the hyperbenthos.

The majority of Lohmannella species have an elongate gnathosoma with long, slender rostrum and palps. Each one of the pair of narrow chelicerae ends with a small claw. The shape of this claw looks similar, though it is smaller than claws of many other similar-sized non-Lohmannella halacarids. The pharyngeal plate of Lohmannella species is short and does not reach to or beyond the basal margin of the gnathosoma, as it does in most halacarids. The palps of Lohmannella are in dorsal position. P-1 generally stand immediately adjacent, rarely separated from each other by $0.5-1 \mathrm{P}$ 1-width; alternatively, the P-1 may be interlocked or even fused, forming a solid basis. The following segments are more or less cylindrical, parallelly arranged and curved ventrad. P-2 and P-3 have a short, scaliform dorsal process, which obviously keeps each following segment in a slightly downward bent position. The tip of P-4 meets that of the rostrum. Palps and rostrum form a pair of pincers. When creeping around in a substratum rich in fissures, Lohmannella may stick its slender rostrum and palps into microcavernes. Here they meet protozoa, fungi, bacterial aggregation, and epithelial cells of a macro- and meiofauna. The cells may be pierced or slashed by the cheliceral claws, digestive enzymes injected and the dissolved cell contents ingested. One may also speculate that species with very long palps (e.g., L. fukushimai) use them to rake drifting food particles from the water column.

Representatives of other halacarid genera have no such pincer-like combination of palps and rostrum. The palps are mostly straight, inserted laterally. In a few halacarid species, the rostrum reaches distinctly beyond the tips of palps; in others, it hardly extends beyond the middle of P-2. In other species, the palps form a trough, which encloses a needle-like rostrum and slender chelicerae (e.g., Australacarus). The palps may also be reduced and represented by two very short segments (e.g., Enterohalacarus) or by only a few setae (e.g., Spongihalacarus).

The commonly collected Lohmannella falcata has often been found amongst hydrozoans and bryozoans (pers. obs.). Do the mites feed on these organisms? Bavestrello et al. (2000) observed and described how halacarids attacked hydrozoans: namely, the mites climbed the polyps, perforated the body, inserted the gnathosoma into the gastral cavity of the hydroids, and, after several minutes, removed the gnathosoma and disappeared. 
Bavestrello et al. (2000) expected the halacarids to have ingested the content of the gastral cavity. The authors (Bavestrello et al. 2000) published a drawing of a halacarid mite, thereby demonstrating the presence of halacarids on hydrozoans. The specific identity of the mite visiting hydrozoans is not known, however.

\section{Distribution and reflections on special character states}

The genus Lohmannella may date back to the Late Triassic epoch, making it about 200 million years old (Pepato et al. 2018). Nowadays, the genus is spread worldwide (Fig. 4): it inhabits climatic zones that range from tropical to polar regions, as well as depth zones that range from mid-tidal to deep sea. At present, more marine species have been described from the southern than from the northern hemispheres: namely, 22 vs. 12 species, respectively (unnamed species excluded) (Table 2). These numbers may quickly change. Large geographical regions that include many habitats have not yet been studied, and, of the above outlined but unnamed species, some will have to be described as a new species. We especially expect an increase in the number of species in the north. The knowledge of the northern Pacific halacarid fauna, especially that of Lohmannella, is sparse. Similarly, the fauna of the western North Atlantic is poorly known. Moreover, we have to expect misidentifications. Accordingly, Fig. 4 in large part reflects the result of sampling activities, rather than informs us about the numbers or presence/absence of Lohmannella species in a given region.

With respect to the depth zones, 30 marine Lohmannella species have been found between the lower tidal zone and the $200 \mathrm{~m}$ depth; 6 (7 if deep water records of $L$. falcata are included) species between 201 and 1,000 m; and three species from the depth beyond 1,000 m. Lohmannella fukushimai has records from the 190-1,047 m depth range; $L$. antarctica records range from the shallow subtidal zone to the $260 \mathrm{~m}$ depth; and L. gaussi have been recorded at the 95-385 m depth range. A careful re-examination may prove the presence of cryptic species. In regards to halacarids in general, the zone between the tidal area and the $200 \mathrm{~m}$ depth is the best studied one; accordingly, it is not surprising that most records of Lohmannella species are from this zone.

Many shallow water southern hemisphere Lohmannella species differ from those living in the north (as well as from most species from deep water areas) in a few characters. One of the characters is the presence and size of gland pores. The southern hemisphere Lohmannella species have five pairs of pores; rarely, one or more of the gland pores are replaced by small setae, e.g., in L. fukushimai. The pores of several tidal and shallow water species are distinct: sometimes, one or more pores are enlarged or end in domes. An example of a species with enlarged pores is L. setosa: its pores may reach a diameter of $10 \mu \mathrm{m}$ (Newell 1984: Fig. 726). In most deep-water and northern hemisphere species, the gland pores are minute, vestigial or absent.

Gland pores are found in most halacarid genera, and five pairs of pores, as present in Lohmannella, are expected to be a plesiomorphic state. In Lohmannella, if all pores are present, the most common arrangement of the pores is: glp-1 on AD, glp-2 marginally, generally in the striated integument, glp-3 on the OC, glp-4 and glp-5 on the PD, glp-4 in the anterior half, glp-5 near the posterior margin of the PD. Rarely, the glp- 4 are in the posterior half, or the glp-5 are removed from the posterior margin.

Another widespread marine genus with five pairs of pores is Halacarus. Among the fresh water genera, that number of pores is present in Limnohalacarus, Parasoldanellonyx, Soldanellonyx and Stygohalacarus. In the majority of halacarid genera, the number of pores is reduced to four or less; or, more rarely, one or more pairs of the pores are in a combination with, or replaced by, setae. The first pair of pores seems to be present in almost all halacarid genera, perhaps also in Xenohalacarus. As in Lohmannella, the first pair is generally situated on the $\mathrm{AD}$; rarely, it is in an adjacent position, e.g., in Agaue agauoides (Lohmann, 1907) (in Lohmann 1907a) and Halacarus validus Gimbel, 1919. A few halacarid species-e.g., Copidognathus meridianus Bartsch, 2003-have large internal glands, which open to the exterior via a porus. The idiosoma of this species has the length of $360-380 \mu \mathrm{m}$; two pairs of internal glands have the size of 30-37 $\mu \mathrm{m}$ (Bartsch 2003b: Fig. 1F). This and other Copidognathus species with enlarged glands are inhabitants of warm temperate and tropical areas. One may expect the glands to contain repellents, exuded to protect the mite from predators-e.g., small fish - but, at present, no experiments have been carried out. Large internal glands have not been mentioned in any of the Lohmannella species. The microstructure or the chemical agents of Lohmannella glands are also unknown. 


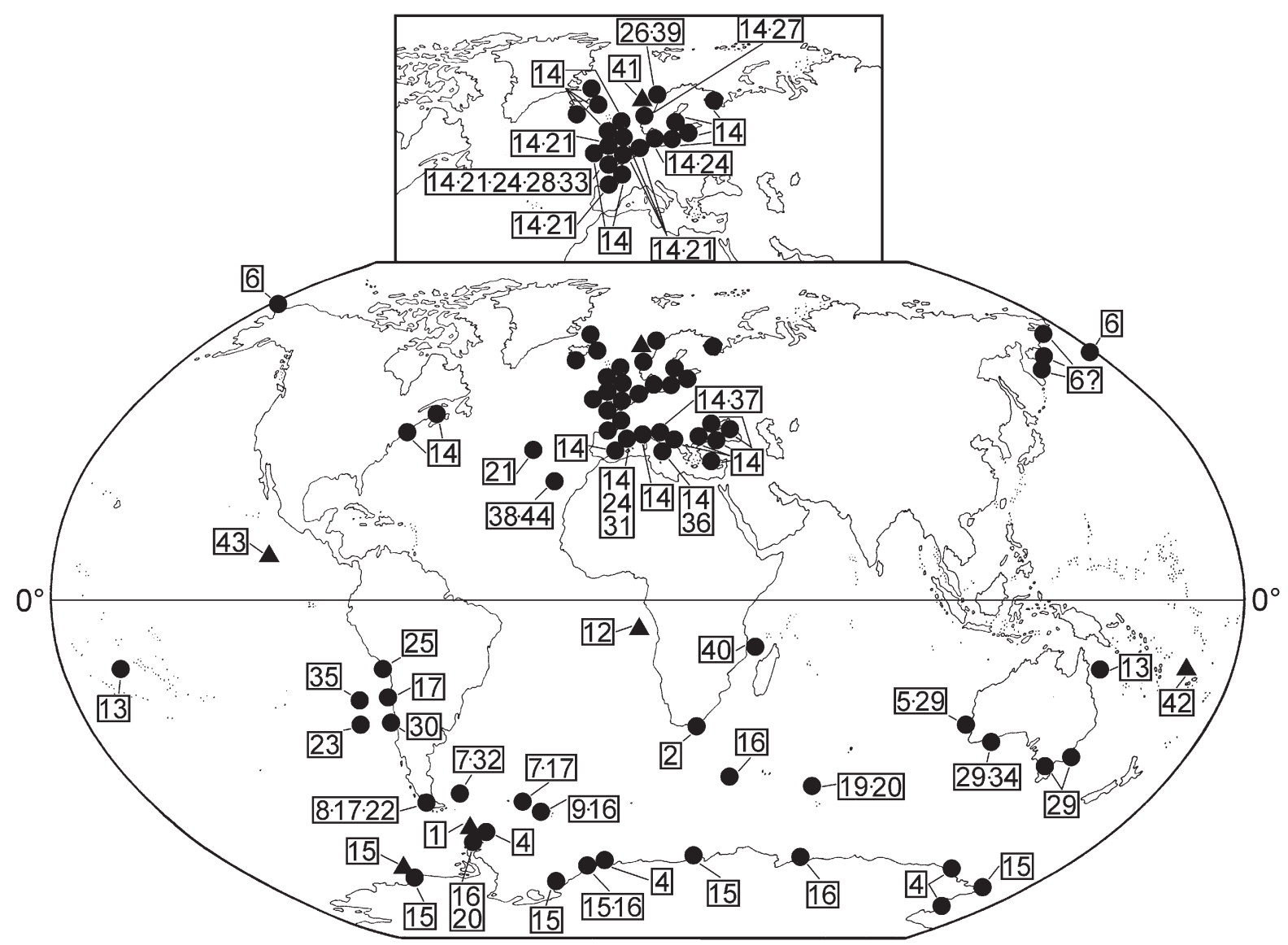

Fig. 4. Records of marine (brackish water) Lohmannella species. Records from the northern Atlantic, from Spain to the White Sea, are in a small separate map. Dots $(\bullet)$ represent records from 0-1,000 m depth, triangles $(\boldsymbol{\Delta})$ - those from the depth of more than 1,000 m. The numbers stand for: 1-abyssalis; 2-africana; 4-antarctica; 5-arenaria; 6-beringi; 7-bihamata; 8-bispina; 9-consimilis; 12-cygna; 13-dictyota; 14-falcata; 15-fukushimai; 16gaussi; 17-grandipora; 19-hureaui; 20-kerguelensis; 21-kervillei; 22-lamellipes; 23-masatierrae; 24multisetosa; 25-multispina; 26-njoerdri; 27—norvegica; 28_nudipes; 29_pinggi; 30-rectangulops; 31-reducta; 32-reticulata; 33-rustica; 34-septemsetosa; 35-setosa; 36-stammeri; 37-steueri; 38-subfalcata; 39—sulensis; 40-sp. A; 41-sp. B; 42-sp. C; 43-sp. D; 44-sp. E (the freshwater species L. andrei, L. curvimandibulata, L. cvetkovi and L. heptapegoni are omitted).

Another easily recognizable character is the presence or absence of spiniform ventral processes on the second palpal segment. Eight Lohmannella species have one or more such processes on P-2. Seven out of eight species are known from the southern hemisphere (unnamed species included). The only record from the northern hemisphere is that listed as Lohmannella sp. E.

Palps and rostrum seem to co-operate like a pair of pincers, but no observations of capturing and preying have been published. One may speculate that the spines on P-2 help to have the prey in a steady grip; but the spines may just as well be used to keep distance from the prey in case it defends itself with chemical or mechanical means. Most species with ventral spines on P-2 have been extracted from tidal or shallow subtidal sand and rubbles; however, one species is from a deep-sea trench (L. abyssalis) and another is from a northeastern Atlantic seamount (Lohmannella sp. E), from about $500 \mathrm{~m}$ depth.

Lohmannella bihamata and L. hureaui (in case the latter one is a separate species), have plumulate fossary setae. Similar plumulate setae, though often less conspicuous, have been mentioned in $\mathrm{Ma}$ karovana (M. hirsuta (Makarova, 1978) and M. spinosa (Bartsch, 1978, in Bartsch 1978b)); Rhombognathus (e.g., R. peltatus Viets, 1939, in Viets 1939b); and two Isobactrus species (I. hutchinsoni Newell 1947 and I. uniscutatus (Viets, 1939) (in Viets 1939b)) (Newell 1947, Makarova, 1978; Bartsch 1978b, 2003c, 2010b). Rhombognathus peltatus lives in habitats exposed to swell and hence, the plumosity may help it adhere to the 
Table 2

Marine and freshwater Lohmannella species and their distributional data (AS, Asia; BGR, Bulgaria; EU, Europe; FRA, France; IO, Indian Ocean; ISR, Israel; ITA, Italia; MNE, Monte Negro (Crna Gora); MD, Mediterranean and Black Seas; NA, North Atlantic; NP, North Pacific; SA, South Atlantic; Nr, the given number of the species as listed in the text; SP, South Pacific)

\begin{tabular}{|c|c|c|c|c|c|c|c|c|c|c|}
\hline \multirow[b]{2}{*}{$\mathrm{Nr}$} & \multirow[b]{2}{*}{ Species } & \multicolumn{3}{|c|}{ marine records from } & \multicolumn{3}{|c|}{ depth (in m) } & \multicolumn{3}{|c|}{ freshwater records from } \\
\hline & & $\begin{array}{c}\text { North } \\
>23^{\circ} \mathrm{N}\end{array}$ & $\begin{array}{c}\text { Tropics } \\
23^{\circ} \mathrm{N}-23^{\circ} \mathrm{S}\end{array}$ & $\begin{array}{c}\text { South } \\
>23^{\circ} \mathrm{S}\end{array}$ & $\begin{array}{c}\text { tidal } \\
-200\end{array}$ & $201-1,000$ & $>1,000$ & $>23^{\circ} \mathrm{N}$ & $23^{\circ} \mathrm{N}-23^{\circ}$ & $>23^{\circ} \mathrm{S}$ \\
\hline 1 & abyssalis & - & - & SA & - & - & $x$ & - & - & - \\
\hline 2 & africana & - & - & IO & $x$ & - & - & - & - & - \\
\hline 3 & andrei & - & - & - & - & - & - & EU (FRA) & - & - \\
\hline 4 & antarctica & - & - & SA & $x$ & $x$ & - & - & - & - \\
\hline 5 & arenaria & - & - & IO & $x$ & - & - & - & - & - \\
\hline 6 & beringi & NP & - & - & $x$ & - & - & - & - & - \\
\hline 7 & bihamata & - & - & SA & $x$ & - & - & - & - & - \\
\hline 8 & bispina & - & - & SP & $x$ & - & - & - & - & - \\
\hline 9 & consimilis & - & - & SA & $x$ & - & - & - & - & - \\
\hline 10 & $\begin{array}{l}\text { curvimandi- } \\
\text { bulata }\end{array}$ & - & - & - & - & - & - & EU (BGR) & - & - \\
\hline 11 & cvetkovi & - & - & - & - & - & - & EU (BGR) & - & - \\
\hline 12 & cygna & - & SA & - & - & - & $x$ & - & - & - \\
\hline 13 & dictyota & - & SP & - & $x$ & - & - & - & - & - \\
\hline 14 & falcata & NA, MD & - & - & $x$ & $?$ & - & - & - & - \\
\hline 15 & fukushimai & - & - & SA, SP & $x$ & $x$ & $x$ & - & - & - \\
\hline 16 & gaussi & - & - & SA, IO, SP & $x$ & $x$ & - & - & - & - \\
\hline 17 & grandipora & - & - & SA, SP & $x$ & - & - & - & - & - \\
\hline 18 & heptapegoni & - & - & - & - & - & - & AS (ISR) & - & - \\
\hline 19 & hureaui & - & - & IO & $x$ & - & - & - & - & - \\
\hline 20 & kerguelensis & - & - & IO & $x$ & - & - & - & - & - \\
\hline 21 & kervillei & NA & - & - & $x$ & - & - & - & - & - \\
\hline 22 & lamellipes & - & - & SP & $x$ & - & - & - & - & - \\
\hline 23 & masatierrae & - & - & SP & $x$ & - & - & - & - & - \\
\hline 24 & multisetosa & NA, MD & - & - & $x$ & - & - & - & - & - \\
\hline 25 & multispina & - & - & SP & $x$ & - & - & - & - & - \\
\hline 26 & njoerdri & NA & - & - & - & $x$ & - & - & - & - \\
\hline 27 & norvegica & NA & - & - & $x$ & - & - & - & - & - \\
\hline 28 & nudipes & NA & - & - & $x$ & - & - & - & - & - \\
\hline 29 & pinggi & - & - & $\mathrm{IO}, \mathrm{SP}$ & $x$ & - & - & - & - & - \\
\hline 30 & rectangulops & - & - & SP & $x$ & - & - & - & - & - \\
\hline 31 & reducta & MD & - & - & $x$ & - & - & - & - & - \\
\hline 32 & reticulata & - & - & SA & $x$ & - & - & - & - & - \\
\hline 33 & rustica & NA & - & - & $x$ & - & - & - & - & - \\
\hline 34 & septemsetosa & - & - & IO & $x$ & - & - & - & - & - \\
\hline 35 & setosa & - & - & SP & $x$ & - & - & - & - & - \\
\hline 36 & stammeri & $(\mathrm{MD})^{*}$ & - & - & $x$ & - & - & EU (ITA, MNE) & - & - \\
\hline 37 & steueri & MD & - & - & $x$ & - & - & - & - & - \\
\hline 38 & subfalcata & NA & - & - & - & $x$ & - & - & - & - \\
\hline 39 & sulensis & NA & - & - & - & $x$ & - & - & - & - \\
\hline 40 & sp. A & - & IO & - & - & $x$ & - & - & - & - \\
\hline 41 & sp. B & NA & - & - & - & - & $x$ & - & - & - \\
\hline 42 & sp. C & - & SP & - & - & - & $x$ & - & - & - \\
\hline 43 & sp. D & - & NP & - & - & - & $x$ & - & - & - \\
\hline 44 & sp. E & NA & - & - & - & $x$ & - & - & - & - \\
\hline
\end{tabular}


surface of the substratum. Makarovana seems to be primarily an inhabitant of the upper tidal area of beaches with sand, pebbles and broken shell (Bartsch and Schmidt 1979). The two Isobactrus species are generally found in moderately exposed or lentic parts of shores. The two species share the following ecological characteristic: they can both live in low saline brackish water, periodically below $1 \mathrm{~S} \%$ (Bartsch 1974, 2011). The fossary setae of the males are slightly plumulate, those of females are almost slender. This difference may correlate with the salinity (chemistry) of the water inhabited. Sperm transfer is via spermatophores (Kirchner 1967; Bartsch 2006b). Halacarids in general live in polyhaline brackish and marine water; the two Isobactrus species also live in low saline brackish water. Due to the plumosity, the surface of the fossary seta is enlarged, possibly making the recognition of signals by the sexual partner easier. The collecting data of Lohmannella bihamata and L. hureaui are too sparse to support any speculation.

Salinity data on marine Lohmannella species are scarce. The majority of species have been extracted from coastal or offshore environments, rarely from areas with highly fluctuating or almost constantly low salinity. Presently, we know that L. falcata is marine, but in the Baltic it is still present at about $7 \mathrm{~S} \%$. Five species are known from fresh or low saline waters: Lohmannella andrei, L. curvimandibulata, L. cvetkovi, L. heptapegoni and L. stammeri. Lohmannella falcata has internal genital acetabula; these are, as in the majority of the marine species, small and obscured by the genital sclerites. In females, the three pairs of acetabula are arranged in a line, distanced from each other (Fig. 2E); in males, they are close together, concentrated in the posterior half of the GO. The acetabula of $L$. andrei, L. curvimandibulata and $L$. cvetkovi are illustrated as being external. Lohmannella heptapegoni and L. stammeri have rather small internal acetabula (Viets 1939a: Figs. 7 and 8; Petrova 1966), which are covered by the genital sclerites. Acetabula have an ion permeable membrane (in contrast to the other almost ionimpermeable parts of the integument) and are consequently expected to be osmoregulatorily active areas (Bartsch 1973b). At least one of the marine Lohmannella species, namely L. multisetosa, has enlarged acetabula (Bartsch 1986: Fig. 19). All present records of that species are from marine habitats. In the Mediterranean, off Marseille coast (France), females had been collected in al- most all months throughout the year. All females had enlarged acetabula (Bartsch 1986). There is no evidence of any relationship between the size of the acetabula and the periods of reproduction.

The majority of halacarid species have been found in salinities, from marine to polyhaline brackish water areas (about 35 to $25 \mathrm{~S} \%$ ). Only a few marine genera have representatives in almost constantly fresh to slightly saline $(<3 \mathrm{~S} \%$ ) water: Lohmannella, Copidognathus and Halacarellus. The genus Acarothrix seems to be restricted to brackish water. Acarothrix males have external acetabula, which obviously are in direct contact with the surrounding water; females have internal acetabula, covered by the genital sclerites (Bartsch 2004b, 2015). The acetabula of all known freshwater Copidognathus species are internal, but these species (both females and males) have enlarged epimeral pores. Males of a few freshwater inhabiting Halacarellus species have external genital acetabula, whereas in females they are covered by the genital sclerites. One may add Halacaroides and Isobactrus to the aforementioned three genera. Representatives of Halacaroides have been found in beach areas strongly influenced by fresh water, and here, too, males have external genital acetabula (Bartsch 2008b; Pepato et al. 2011). The two Isobactrus species-I. hutchinsoni and I. uniscutatus - can survive a long-term stay in freshwater. They often inhabit areas with changing salinities, nearshore ponds and tidal banks of rivers and creeks (Newell 1947; Bartsch 1979a, 2011). In the Elbe River (Germany), I. uniscutatus penetrates far into the freshwater part of the river; however, here it is restricted to the middle and upper tidal area, regularly emerging during low tide (Bartsch 2019). A somewhat similar reaction with respect to a long-term stay in freshwater was demonstrated by Gressitt (1967): namely, the halacarid Rhombognathus gressitti Newell, 1967 proved to tolerate fresh water, but needed periods of drying.

Records of freshwater Lohmannella species come from areas adjacent to or restricted to areas that were once under the influence of the western and north-eastern parts of the Tethys Sea (ProtoMediterranean and Paratethys, respectively). In the beginning of the Tertiary, the 'Southern EuropeMediterranean-Middle East' region experienced a tectonic land rise, which led to the isolation of the western Tethys from the Atlantic and the Indian Oceans, changed the course of rivers (e.g., the Danube) and separated the Proto-Mediterranean 
and Paratethys (Adams 1981). Each new water body had its own history. In the late Mio- and Pliocene, the Paratethys became a vast system of fresh and brackish water lakes and channels. During its major extension, it went from Vienna (Austria) to the Aral Sea (Fink 1966; Adams 1981). The Proto-Mediterranean Sea largely desiccated (Hsü et al. 1977). Did marine species in some parts of the land-locked Tethyan or Paratethyan population become adapted to life in low salinity and speciated? Such speciation would go back to the late Miocene/Pliocene. In that case, the freshwater Lohmannella species, known from France, Italy, Monte Negro, Bulgaria and Israel, may have an age of about five million years. This is distinctly less than the calculated age of many almost exclusively freshwater inhabiting halacarid species, which are expected to have invaded freshwater in the Mesozoic or even in the Pre-Mesozoic (Bartsch 1996, 2007b). However, we cannot exclude the following scenario: freshwater Lohmannella species known from Western Europe and Middle Asia do not descend from Tethyan fauna, but from tribes which once colonized freshwater-influenced peripheral parts of the epicontinental seas and which locally survived the evaporation of these seas. The lack of records of freshwater Lohmannella from the middle and northern parts of continental Europe, as well as from other continents that were once covered by large seas, speaks against the scenario described above.

More detailed morphological descriptions and genetic data are necessary to answer the following questions: 1) do present-day European/Middle East freshwater Lohmannella species descend from just one or several species? and 2) are all present-day European/Middle East freshwater Lohmannella species closely related to present-day marine species in the Mediterranean or adjacent basins, which once were covered by the Tethys? Additionally, it will be of interest to learn if other continents with analogous tectonic events (or the ones that have also been periodically covered by epicontinental seas) harbour freshwater Lohmannella species. As of yet, no such records have been published.

\section{ACKNOWLEDGEMENTS}

I am grateful to the Deutsches ElektronenSynchroton (DESY), Hamburg, for offering me workspace in the institution. I would also like to thank Dr. H. Dastych and Dr. N. Dupérré (Arachnology Collection, Zoologisches Museum, Ham- burg (Leibniz-Institut zur Analyse des Biodiversitätswandels)), Dr. T. Kronestedt (Naturhistoriska Riksmuseet, Stockholm) and Dr. P. Jäger and Dr. J. Altmann (Senckenberg Institut und Museum, Frankfurt am M.) for loaning me the slides deposited in the halacarid collections.

\section{REFERENCES}

Adams, C. G. 1981. An outline of Tertiary palaeogeography. In: L.R.M. Cocks (Ed.). The Evolving Earth. Cambridge University Press, Cambridge, pp. 221-235.

André, M. 1946. Halacariens marins. Faune de France, 46: 1-152.

Angelier, E. 1951. Porolhomannella andrei n.sp., un nouvel halacarien recueilli dans de psammon d'eau douce. Bulletin du Muséum National d'Histoire Naturelle, Série 2, 23: 505-507.

Angelier, E. 1965. Les Porohalacaridae de la faune française. Annales de Limnologie, 1: 213-220.

Bartsch, I. 1972. Ein Beitrag zur Systematik, Biologie und Ökologie der Halacaridae (Acari) aus dem Litoral der Nord- und Ostsee. I. Systematik und Biologie. Abhandlungen und Verhandlungen des Naturwissenschaftlichen Vereins zu Hamburg, Neue Folge, 16: 155-230.

Bartsch, I. 1973a. Halacaridae (Acari) von der Josephinebank und der großen Meteorbank aus dem östlichen Nordatlantik. II. Die Halacaridae aus den Schleppnetzproben. Meteor Forschungs-Ergebnisse, Reihe D, 13: 37-46.

Bartsch, I. 1973b. Porohalacarus alpinus (Thor) (Halacaridae, Acari), ein morphologischer Vergleich mit marinen Halacariden nebst Bemerkungen zur Biologie dieser Art. Entomologisk Tidskrift, 94: 116-123.

Bartsch, I. 1974. Ein Beitrag zur Systematik, Biologie und Ökologie der Halacaridae (Acari) aus dem Litoral der Nord- und Ostsee. II. Ökologische Analyse der Halacaridenfauna. Abhandlungen und Verhandlungen des Naturwissenschaftlichen Vereins zu Hamburg, Neue Folge, 17: 9-53.

Bartsch, I. 1977. New species of Lohmannella (Halacaridae, Acari) from the Roscoff area, Brittany. Cahiers de Biologie Marine, 18: 141-153. DOI: 10.21411/CBM.A.EBD7ABF5

Bartsch, I. 1978a. Halacaridae (Acari) aus der Tiefsee des atlantischen Ozeans. Cahiers de Biologie Marine, 19: 47-62.DOI: 10.21411/CBM.A.BD1B723B

Bartsch, I. 1978b. Halacaridae (Acari) von Gezeitenstränden Nordnorwegens. Mikrofauna des Meeresbodens, 70: 1-22. 
Bartsch, I. 1979a. Halacaridae (Acari) von der Atlantikküste Nordamerikas. Beschreibung der Arten. Mikrofauna des Meeresbodens, 79: 1-62.

Bartsch, I. 1979b. Halacaridae (Acari) aus der Subantarktis. Cahiers de Biologie Marine, 20: 325-339. DOI: 10.21411/CBM.A.326F4A10

Bartsch, I. 1982. Weitere Halacaridae (Acari) aus dem Kanal von Moçambique. Cahiers de Biologie Marine, 23: 435-457.

Bartsch, I. 1986. Lohmannellinae (Halacaroidea, Acari) aus dem Mittelmeer. Entomologische Mitteilungen aus dem Zoologischen Museum Hamburg, 8: 231-244.

Bartsch, I. 1988. Deep-sea halacarids (Acari) and description of a new species. Journal of Natural History, 22: 811-821.

Bartsch, I. 1991. Taxonomic notes on halacarids (Acari) from the Skagerrak area. Helgoländer Meeresuntersuchungen, 45: 97-106.

Bartsch, I. 1992a. Lohmannella dictyota n.sp. und L. africana n.sp. von der Südhalbkugel (Arachnida: Acari: Halacaridae). Senckenbergiana Biologica, 72: 457-464.

Bartsch, I. 1992b. Phacacarus flavellus gen. et spec. nov. (Copidognathinae, Halacaroidea, Acari), eine Meeresmilbe auf Kalkalgen. Zoologischer Anzeiger, 228: 212-219.

Bartsch, I. 1993a. A synopsis of the Antarctic Halacaroidea (Acari). In: J. W. Wägele and J. Sieg (Eds.). Synopses of the Antarctic Benthos, vol. 4. Koeltz, Koenigstein. 176 pp.

Bartsch, I. 1993b. Arenicolous Halacaridae (Acari) from south-western Australia. In: F.E. Wells, D. I. Walker, H. Kirkman and R. Lethbridge (Eds). The Marine Flora and Fauna of Rottnest Island, Western Australia. Western Australian Museum, Perth, pp. 73-103.

Bartsch, I. 1994. Sexualdimorphismus bei Meeresmilben (Halacaridae, Acari). Übersicht und Beschreibung des Männchens von Phacacarus flavellus. Zoologischer Anzeiger, 232: 61-74.

Bartsch, I. 1996. Halacarids (Halacaroidea, Acari) in freshwater. Multiple invasions from the Paleozic onwards? Journal of Natural History, 30: 67-99.

Bartsch, I. 2003a. Lohmannellinae (Halacaridae: Acari) from the Great Meteor Seamount (Northeastern Atlantic). Description of new species and reflections on the origin of the seamount fauna. Mitteilungen aus dem Hamburgischen Zoologischen Museum und Institut, 100: 101-117.

Bartsch, I. 2003b. Psammophilous halacarids (Halacaridae: Acari) from Dampier, Western Australia. Description of species and faunal comparison of the mesopsammal halacarid fauna of western and eastern Australia. Records of the Western Australian Museum, 22: 23-45.

Bartsch, I. 2003c. The subfamily Rhombognathinae: developmental pattern and re-evaluation of the phylogeny (Arachnida, Acari, Halacaridae). Senckenbergiana biologica, 82: 15-57.

Bartsch, I. 2004a. The Black Sea halacarid fauna (Halacaridae: Acari): faunal comparison with the Mediterranean, Eastern North Atlantic, North Sea and Baltic and reflection on its origin. Mitteilungen aus dem Museum für Naturkunde in Berlin, Zoologische Reihe, 80: 143-158.

Bartsch, I. 2004b. Acarothrix ampliata (Arachnida: Acari: Halacaridae), a new halacarid mite from Florida, with notes on external genital acetabula. Species Diversity, 9: 259-267.

Bartsch, I. 2005a. Halacaridae from the depths of Western Antarctica (Arachnida: Acari). Senckenbergiana Biologica, 85: 31-41.

Bartsch, I. 2005b. Lohmannella and Simognathus (Halacaridae: Acari) from Western Australia: description of two new species and reflections on the distribution of these genera. Records of the Western Australian Museum, 22: 293-307.

Bartsch, I. 2006a. 5. Acari: Halacaroidea. In: R. Gerecke (Ed.). Süßwasserfauna von Mitteleuropa. 7/2-1. Chelicerata: Araneae, Acari I. Elsevier, Spektrum, München, pp. 113-157.

Bartsch, I. 2006b. Halacaroidea (Acari): a guide to marine genera. Organisms Diversity and Evolution 6, Electronic Supplement, 6: 1-104. http://www. senckenberg.de/odes/06-06.htm

Bartsch, I. 2007a. Halacarid mites (Acari: Halacaridae) from Esperance, Western Australia: Notes on taxonomy and faunal distribution of non-Copidognathinae. Records of the Western Australian $\mathrm{Mu}$ seum, 23: 359-392.

Bartsch, I. 2007b. Freshwater Halacaridae (Acari) from New Zealand rivers and lakes, with notes on character variability. Mitteilungen aus dem Hamburgischen Zoologischen Museum und Institut, 104: 73-87.

Bartsch, I. 2008a. Halacaridae (Acari) from Western Antarctica. New data. Entomologische Mitteilungen aus dem Zoologischen Museum Hamburg, 15: 53-61.

Bartsch, I. 2008b. Halacarid mites (Acari) in a freshwater influenced beach of North Stradbroke Island, Moreton Bay, Queensland. In: P.J.F. Davie and J.A. Phillips (Eds). Proceedings of the Thirteens International Marine Biological Workshop. The Marine Fauna and Flora of Moreton Bay, Queensland. Memoirs of the Queensland Museum, 54(1): 117-130. 
Bartsch, I. 2010a. Halacarus excellens Lohmann, 1907 (Acari: Halacaridae), a new record a century later, re-description and notes on this and other Antarctic halacarid species. Entomologische Mitteilungen aus dem Zoologischen Museum Hamburg, 15: 157-170.

Bartsch, I. 2010b. Reflections on distribution and origin of the halacarid genus Isobactrus (Acari: Halacaridae). Marine Biodiversity, 40: 17-32. DOI 10.1007/s12526-009-0030-7

Bartsch, I. 2011. North American freshwater Halacaridae (Acari): literature survey and new records. International Journal of Acarology, 37: 490-510.

Bartsch, I. 2013. A new species, genus Copidognathus (Acari: Halacaridae), from a hydrothermal vent area of the East Pacific Rise. Cahiers de Biologie Marine, 54: 239-246. DOI: 10.21411/CBM.A.CB14DE23

Bartsch, I. 2015. Halacaridae (Acari) amongst the epiflora and fauna on trunks, branches, roots, and pneumatophores on the coast of Singapore: a survey. The Raffles Bulletin of Zoology, Supplement 31: 96-138.

Bartsch, I. 2016. Antarctic Halacaridae (Acari), new records, these species characteristics and an updated list of species. Polish Polar Research, 37: 131-154. DOI: 10.1515/popore-2016-0007

Bartsch, I. 2019. Meeresmilben (Halacaridae: Acari), zwei Neufunde aus der Elbe bei Hamburg. Lauterbornia, 86: 12-20.

Bartsch, I. 2020. Lohmannella (Acari, Halacaridae) from a cold-water coral reef off Norway, description of two new and a list of North Atlantic species. Zootaxa, 4722 (3): 277-286. DOI: 10.11646/zootaxa.3919.2.1

Bartsch, I. and Schmidt, P. 1979. Zur Verbreitung und Ökologie einiger Halacaridae (Acari) in Sandstränden der Ostsee (Kieler Bucht), der Nordsee (Sylt) und des Europäischen Nordmeeres (Tromsö). Mikrofauna des Meeresbodens, 74: 1-37.

Bartsch, I. and Smit, H. 2006. Een checklist van de Nederlandse Zeemijten (Acari: Halacaroidea). Nederlandse faunistische Mededelingen, 25: 25-32.

Baster, J. 1758. Observationes de Corallinis, Iisque Insidentibus Polypis, Aliisque Animalculis Marinis. Philosophical Transactions (1683-1775), 50(17571758): 258-280.

Bavestrello, G., Puce, S., Cerrano, C. and Balduzzi, A. 2000. Life history of Perarella schneideri (Hydrozoa, Cytaeididae) in the Ligurian Sea. Scientia Marina, 64 (Supplement 1): 141-146.

Durucan, F. 2018. 4.3 First record of Lohmannella falcata (Hodge, 1863) (Acari: Halacaridae) from the Mediterranean Sea of Turkey, Antalya. In: N. Chartosia, D. Anastasiadis, H. Bazairi, F. Crocetta, A. De- idun, M. Despalatović, V. Di Martino, N. Dimitriou, B. Dragičević, J. Dulčić, F. Durucan, D. Hasbek, V. Ketsilis-Rinis, P. Kleitou, L. Lipej, A. Macali, A. Marchini, M. Ousselam, S. Piraino, B. Stancanelli, M. Theodosiou, F. Tiralongo, V. Todorova, D. Trkov and S. Yapici. New Mediterranean Biodiversity Records (July 2018). Mediterranean Marine Science, 19/2: 410-411. DOI: 10.12681/mms.18099

Fink, J. 1966. III. Die Paleographie der Donau. Limnologie der Donau, 2: 1-50.

Fountain, H.C. 1953. An examination of the original slides of marine Acari of Hodge, 1863. Journal of the Marine Biological Association of the United Kingdom, 32: 357-364.

Fricke, H., Giere, O., Stetter, K., Alfredsson, G.A., Kristjansson, J.K., Stoffers, P. and Svavarsson, J. 1989. Hydrothermal vent communities at the shallow subpolar Mid-Atlantic ridge. Marine Biology, 102: 425-429.

Gimbel, O. 1919. Über einige neue Halacariden. Mitteilungen aus dem Zoologischen Museum Hamburg, 36: 105-130.

Green, J. and MacQuitty, M. 1987. Halacarid Mites. Synopses of the British Fauna, New Series, vol. 36, $178 \mathrm{pp}$.

Gressitt, L.J. 1967. Notes on arthropod populations in the Antarctic Peninsula-South Shetland IslandsSouth Orkney Islands area. Antarctic Research Series (Entomology of Antarctica), 10: 373-391.

Hodge, G. 1863. Contributions to the marine zoology of Seaham Harbour. On some undescribed marine Acari. Transactions of the Tyneside Naturalists' Field Club, 5(4): 298-303.

Hsü, K., Montadert, L., Bernoulli, D., Cita, M.B., Erickson, A., Garrison, R.E., Kidd, R.B., Mèlierés, F., Müller, C. and Wright, R. 1977. History of the salinity crisis. Nature, 267: 399-403.

Imamura, T. 1968. A new species of halacarid mites from the Antarctic Ocean. Acarologia, 10: 472-476.

Jarvekjul, A. 1979. Donnaya Fauna Vosttočnoi Časti Baltiiskogo Morja. Balgus, Tallin, 382 pp.

Kautsky, H., Widbom, B. and Wulff, F. 1981. Vegetation macrofauna and benthic meiofauna in the phytal zone of the Archipelago of Luleà-Bothnian Bay. Ophelia, 20: 53-77.

Kautsky, N. 1974. Quantitative investigations of the red algal belt in the Askö Area, Northern Baltic Proper. Contributions from the Askö Laboratory, University of Stockholm, 3: 1-29.

Kirchner, W.P. 1967. Spermatophoren bei Halacariden (Acarina). Naturwissenschaften, 53: 345-346.

Kirchner, W.P. 1969. Zur Biologie und Ökologie von Halacarus basteri basteri Johnson 1836 (Acari, Trombidiformes). Oecologia (Berlin), 3, 56-69. 
Kramer, P. 1879. Ueber die Milbengattungen Leptognathus Hodge, Raphignathus Dug., Caligonus Koch und die neue Gattung Cryptognathus. Archiv für Naturgeschichte, 45: 142-157.

Krivolutsky, D.A. and Antsiferova, M.P. 2008. Order Acariformes Zachvatkin 1952. In: E. D. Krasnova, A. V. Tchesunov, N.M. Kaljakina and E. N. Bubnova (Eds). Catalogue of Biota of the MSU White Sea Biological Station. http://biota-en.wsbs-msu. ru/wiki/index.php/Catalogue

Lohmann, H. 1893. Bemerkungen zu den auf der Holsatia-Fahrt 1887 gesammelten Halacarinen. Kommission zur Wissenschaftlichen Untersuchung Deutscher Meere, 6: 199-204.

Lohmann, H. 1901. Halacaridae. Das Tierreich, 13: 273-305.

Lohmann, H. 1907a. Über einige faunistische Ergebnisse der Deutschen Südpolar-Expedition unter besonderer Berücksichtigung der Meeresmilben. Schriften des Naturwissenchaftlichen Vereins für Schleswig-Holstein, 14: 1-14.

Lohmann, H. 1907b. Die Meeresmilben der Deutschen Südpolar-Expedition 1901-1903. In: E. von Drygalski Deutsche Südpolar-Expedition 1901-1903. Vol. 9. G. Fischer, Jena, pp. 361-413.

Makarova, N.G. 1977. [Marine mites (Acarina, Halacaridae) of the intertidal zone of the Kurile Islands]. In: V. V. Gulbin, M. B. Ivanova, O.G. Kusakin and T.F. Tarakanova (Eds). Fauna Pribreznih Zon Kurilskih Ostrovov. Nauka, Moscow, pp. 125-143. [In Russian]

Makarova, N.G. 1978. [Marine mites (Acarina, Halacaridae) from the intertidal zone of the Gulf of Anadyr (Bering Sea)]. In: O.G. Kussakin (Ed.). The Intertidal Zone of the Bering Sea and SouthEastern Kamchatka. Nauka, Moscow, pp. 131149. [In Russian, with English summary]

Martínez, A., García-Gómez, G., García-Herrero, Á., Sánchez, N., Pardos, F., Izquierdo-Muñoz, A., Fontaneto, D. and Mammola, S. 2021. Habitat differences filter functional diversity of low dispersive microscopic animals (Acari, Halacaridae). Hydrobiologia, 848: 2681-2698. DOI: 10.1007/ s10750-021-04586-x

Motaş, C. 1961. Halacaridae. In: The Zoology of Iceland. Vol. III, part 55. Ejnar Munksgaard, Copenhagen and Reykjavik. 20 pp.

Newell, I.M. 1947. A systematic and ecological study of the Halacaridae of eastern North America. Bulletin of the Bingham Oceanographic Collection, 10: 1-232.

Newell, I. M. 1951. Further studies on Alaskan Halacaridae (Acari). American Museum Novitates, 1536: $1-56$.
Newell, I. M. 1967. Prostigmata: Halacaridae (marine mites). Antarctic Research Series, 10: 81-95.

Newell, I.M. 1984. Antarctic Halacaroidea. Antarctic Research Series, 40: 1-284.

Otto, J.C. 1994. New species of Halacaridae from Australia (Acarina: Prostigmata). Acarologia, 35: $31-48$.

Otto, J.C. 2000. Halacaridae from the Great Barrier Reef and Coral Sea: the genera Lohmannella, Scaptognathides and Scaptognathus (Acarina: Halacaridae: Lohmannellinae). Memoirs of the Queensland Museum, 45: 535-555.

Pepato, A.R. 2010. Posiçao filogenética dos ácaros Actinotrichida (Chelicerata) e espermatologia comparada dos Halacaridae (Actinotrichida). Tese de doutorado. Universidade de Sao Paulo. http.// www.teses.usp.br/teses/disponiveis/41/41133/tde02032010-110711/

Pepato, A.R., Tiago, C.G. and da Rocha, C.E.F. 2011. Psammophilous halacarid mites (Trombidiformes, Halacaridae) from the North Coast of São Paulo State, Brazil. Zootaxa, 2823: 47-60.

Pepato, A.R., Vidigal, T.H.D.A., Pavel, B. and Klimov, P.B. 2018. Molecular phylogeny of marine mites (Acariformes: Halacaridae), the oldest radiation of extant secondarily marine animals. Molecular Phylogenetics and Evolution, 129(2): 182-188.

Pešić, V. 2004. Three interesting halacarid mite species (Acari: Halacaroidea) from Montenegro and Italy. Lauterbornia, 49: 37-42.

Petrova, A. 1965. [Hydracariens phréaticoles de la Thrace]. In: Die Fauna Trakiens, II, Sofia, Bulgarian Academy of Science, Zoological Institute and Museum. Vol. 2, pp. 329-338. [In Bulgarian, with Russian and French summary]

Petrova, A. 1966. Deux nouveaux halacariens d'Israël - Limnohalacarus capernaumi n.sp. et Lohmannella heptapegoni n. sp. International Journal of Speleology, 2: 355-362.

Petrova, A. 1969. Sur les représentants du genre Porolohmannella en Bulgarie: Porolohmannella cvetkovi Petrova 1965 et Porolohmannella curvimanidibulata n.sp. (Limnohalacaridae, Acari). Archiv für Hydrobiologie, 66: 100-106.

Petrova, A., Angelkova, E.B., Cvetkova, R.L. and Bukureshtliev, D.A. 1991. [Biological state of ground water in the Zlatica-Pirdop basin]. Chidrobiologia-Hydrobiology, Sofia, 36: 3-12. [In Bulgarian, with English summary]

Pugh, P.J.A. 1988. The shore-dwelling Acari of the Isles Scilly and the South-West Peninsula. Journal of Natural History, 22: 931-948.

Pugh, P.J.A. and Bartsch, I. 1994. Ecology of the littoral Halacaridae (Acari: Prostigmata) of South 
Georgia in the sub-Antarctic. Journal of Natural History, 28: 75-85.

Riesgo, A., Pérez-Portela, R. and Arroyo, N.L. 2010. Halacarid mites (Acari: Halacaridae) associated with a North Atlantic subtidal population of the kelp Laminaria ochroleuca. Journal of Natural History, 44(11): 651-667.

Sokolov, I.I. 1952. Vodjanye klešči. II. Halacarae. Fauna SSSR, 5. Izdatelstvo Akademii NAUK SSSR, Moscow, Leningrad. 201 pp. [In Russian]

Somerfield, P. 1988. New records of marine Halacaridae (Acari: Prostigmata) from rocky shores around the Irish coast. Bulletin of the Irish Biogeographical Society, 11: 6-21.

Somerfield, P. 1991. Additional records of marine Halacaridae (Acari: Prostigmata) from Ireland. Bulletin of the Irish biogeographical Society, 14: 2-23.

Straarup, J.-O. 1968. On the life cycles of halacarids (Acari) from the Øresund. Ophelia, 5: 255-271.

Svenonius, B. 1949. Über die Hydracarinenfauna im Bottenviken und im angrenzenden Küstengebiet. Entomologisk Tidskrift, 70: 253-256.

Trouessart, E.L. and Neumann, G. 1894. Note sur les acariens marins (Halacaridae) récoltés par M. Henri Gadeau de Kerville sur le littoral du départment de la Manche (Juillet-Août 1893). Bulletin de la Société Amis des Sciences Naturelles, Rouen, 9: 139-175.

Trouessart, E.L. and Neumann, G. 1896. Halacariens. Résultats scientifiques de la Campagne du 'Caudan' dans le Golf de Gascogne. Annales de l'Université de Lyon, 26: 325-353.
Trouessart, E.L. and Neumann, G. 1901. Note sur les Acariens marins (Halacaridae) récoltés par M. Henri de Gadeau de Kerville dans la région d'Omonville-la-Rogue (Manche) et dans la Fosse de la Hague. Bulletin de la Société Amis des Sciences Naturelles, Rouen. Série 4, 14: 247-266.

Viets, K. 1927a. Halacaridae. Tierwelt der Nord- und Ostsee, XI: 1-72.

Viets, K. 1927b. Die Halacaridae der Nordsee. Zeitschrift für Wissenschaftliche Zoologie, 130: 83-173.

Viets, K. 1939a. Halacariden (Acari) aus süditalienischen Höhlengewässern (12. Mitteilung über Wassermilben aus unterirdischen Gewässern). Archiv für Hydrobiologie, 35: 625-630.

Viets, K. 1939b. Meeresmilben aus der Adria (Halacaridae und Hydrachnellae, Acari). Archiv für Naturgeschichte (Neue Folge), 8: 518-550.

Viets, K. 1940. Meeresmilben aus der Adria (Halacaridae und Hydrachnellae, Acari). Archiv für Naturgeschichte (Neue Folge), 9: 1-135.

Viets, K. 1950. Die Meeresmilben (Halacaridae, Acari) der Fauna Antarctica. Further Zoological Results of the Swedish Antarctic Expedition, 4(3): 1-44.

Viets, K. 1952. Nachträge zu „Die Meeresmilben (Halacaridae, Acari) der Fauna Antarctica“. Further Zoological Results of the Swedish Antarctic Expedition, 4(10): 1-11.

Viets, K. 1956. Die Milben des Süßwassers und des Meeres. Katalog der Halacaridae, Meeresmilben. II. Abschnitt. In: K. Viets (Ed.). Die Milben des Süßwassers und des Meeres. Hydrachnellae et Halacaridae. Fischer Verlag, Jena, pp. 641-870. 